UNIVERSIDADE DE SÃO PAULO

ESCOLA DE ARTES, CIÊNCIAS E HUMANIDADES

PROGRAMA DE PÓS-GRADUAÇÃO EM MUDANÇA SOCIAL E

PARTICIPAÇÃ̃O POLÍTICA

ROGÉRIO MACHADO LIMONTI TIBURCIO

O Custo Aluno-Qualidade como eixo do sistema nacional de educação: enfrentamento histórico ou miragem retórica 
ROGÉRIO MACHADO LIMONTI TIBURCIO

\section{O Custo Aluno-Qualidade como eixo do sistema nacional de educação: enfrentamento histórico ou miragem retórica}

Dissertação apresentada à Escola de Artes, Ciências e Humanidades da Universidade de São Paulo para obtenção do título de Mestre em Ciências pelo Programa de Pós-graduação em Mudança Social e Participação Política.

Versão corrigida contendo as alterações solicitadas pela comissão julgadora em 15 de março de 2019. A versão original encontra-se em acervo reservado na Biblioteca da EACH/USP e na Biblioteca Digital de Teses e Dissertações da USP (BDTD), de acordo com a Resolução CoPGr 6018, de 13 de outubro de 2011.

Área de Concentração:

Financiamento da Educação

Orientadora:

Profa Dra. Ursula Dias Peres 
Autorizo a reprodução e divulgação total ou parcial deste trabalho, por qualquer meio convencional ou eletrônico, para fins de estudo e pesquisa, desde que citada a fonte.

Tiburcio, Rogério Machado Limonti

O custo aluno-qualidade como eixo do sistema nacional de educação: enfrentamento histórico ou miragem retórica / Rogério Machado Limonti Tiburcio ; orientadora, Ursula Dias Peres. 2019 $144 \mathrm{f}:$ il.

Dissertação (Mestrado em Ciências) - Programa de PósGraduação em Mudança Social e Participação Política, Escola de Artes, Ciências e Humanidades, Universidade de São Paulo

Versão corrigida

1. Política educacional - Brasil. 2. Financiamento da educação - Brasil. I. Peres, Ursula Dias, orient. II. Título. CDD 22.ed. - 379.20981 
Nome: TIBURCIO, Rogério Machado Limonti

Título: O Custo Aluno-Qualidade como eixo do sistema nacional de educação:

enfrentamento histórico ou miragem retórica

Dissertação apresentada à Escola de Artes, Ciências e Humanidades da Universidade de São Paulo para obtenção do título de Mestre em Ciências pelo Programa de Pós-graduação em Mudança Social e Participação Política.

Área de Concentração:

Financiamento da Educação

Aprovado em: 15/03/2019

\section{Banca Examinadora}

Ana Paula Fracalanza

Universidade de São Paulo. Escola de Artes Ciências e Humanidades

Nelson Machado

Fundação Getúlio Vargas. Escola de Economia de São Paulo

Luís Fernando Massonetto

Universidade de São Paulo. Faculdade de Direito 
Ao meu pai, Marcos Antônio Limonti, filho de agricultores, de genialidade ímpar, que encontrou na profissão de eletricista a melhor forma de expressar o seu espírito inquieto. 


\section{Agradecimentos}

À minha companheira Walquiria Tiburcio Limonti, que me inspira, me fortalece, me ensina e não esmorece nas lutas que encampa.

À minha filha Dandara, que chegou no meio do mestrado e me convida a refletir sobre o caminho a percorrer a cada dia.

Aos amigos e familiares que me apoiaram e incentivaram nesses últimos anos, em especial, a Maria Isabel, Wanessa Tiburcio, Laura Tiburcio, Gláucia Limonti, Marcos Limonti e meus irmãos, Ricardo e Marcos Limonti, que sempre se fizeram presente nos momentos mais difíceis.

À Professora Dra. Ursula Dias Peres, pela confiança, atenção, apoio e discussão que excede ao processo de orientação.

Ao DIEESE por todos os momentos de reflexão e aprendizado.

À APEOESP que me proporcionou vivenciar às dores e os sabores dos trabalhadores e trabalhadoras da educação.

Aos colegas e amigos da Liderança do PT da Câmara Municipal de São Paulo pela solidariedade, compreensão e dedicação nestes tempos duros.

À Escola de Artes, Ciências e Humanidades pela oportunidade de realização do curso de mestrado. 


\section{RESUMO}

TIBURCIO, Rogério Machado Limonti. O Custo Aluno-Qualidade como eixo do Sistema Nacional de Educação: enfrentamento histórico ou miragem retórica. 2019. 144 f. Dissertação (Mestrado em Ciências) - Escola de Artes, Ciências e Humanidades, Universidade de São Paulo, São Paulo, 2019. Versão corrigida.

Esta dissertação questiona as estruturas de composição e distribuição dos recursos para manutenção e desenvolvimento do ensino dos estados e municípios no seu princípio base, os mecanismos implementados no Fundo de Manutenção e Desenvolvimento do Ensino Fundamental e Valorização do Magistério (Fundef) que se perpetuam no Fundo de Manutenção e Desenvolvimento da Educação Básica e Valorização do Magistério (Fundeb) e tem continuidade com o Custo Aluno-Qualidade (CAQ), em especial, a métrica de distribuição de recursos segundo o número de matrículas. Além de revisão bibliográfica sobre financiamento da educação brasileira realizou-se pesquisa quantitativa com dados sobre finanças públicas municipais, por meio do FINBRA, exame de dados educacionais do Censo Escolar e análise comparada da matriz de custos do CAQ em relação a rede de ensino municipal da cidade de São Paulo. O percurso percorrido evidenciou a disparidade da participação dos municípios na composição de recursos do Fundeb, os processos de indução de fechamento de escolas e turmas decorrente da métrica de distribuição de recursos por aluno, a ascensão do CAQ como justificativa para o aumento do aporte de recursos para as políticas educacionais, juntamente, com a fragilidade do discurso sobre a destinação de novas fontes à educação, à priori, de tributos de competência da União. Ademais, aborda as dificuldades do CAQ em se firmar como mecanismo de repasse dos recursos da manutenção e desenvolvimento do ensino. Se por um lado é inegável o papel histórico do CAQ na ampliação de recursos para educação, por outro este não se desenvolveu metodologicamente para imprimir as premissas qualitativas do indicador à política de fundos. Em suma demonstra-se que outros fatores possuem maior relevância na divisão dos custos do que o aluno. Novas métricas para repasse de recursos permitiriam a incorporação de diretrizes na estrutura do fundo induzindo práticas de incentivo a abertura de turmas e a ampliação do tempo da jornada escolar.

Palavras chave: Financiamento da Educação. Fundef. Fundeb. Custo Aluno-Qualidade. 


\begin{abstract}
TIBURCIO, Rogério Machado Limonti. The cost Student-Quality as axis of the National Education System: historical confrontation or rhetorical mirage. 2019. $144 \mathrm{f}$. Dissertation (Master in Sciences) - School of Arts, Sciences and Humanities, University of São Paulo, São Paulo, 2019. Corrected version.
\end{abstract}

This dissertation questions the composition's structures and distribution of the resources for maintenance and development of the teaching of the states and municipalities in its basic principle, the mechanisms implemented in Fund for maintenance and development of elementary education and recognition of Teaching (Fundef) that are perpetuated in Fund for the Maintenance and Development of Basic Education and recognition of Education Professionals (Fundeb) and has continuity with the Cost Student-Quality(CAQ), in particular, the metric distribution of resources according to the number of enrollments. In addition to a bibliographical review on the financing of Brazilian education, a quantitative research was carried out with data on municipal public finances, through FINBRA (Brazil's Finance), an examination of educational data from "Censo Escolar", and a comparative analysis of the CAQ's cost matrix in relation to the municipal education network of Sao Paulo City. The trajectory evidenced the disparity of the participation of municipalities in the composition of Fundeb resources, the induction' processes of schools' closure and classes resulting from the metric of resources' distribution per student, the rise of the CAQ(Cost of Quality Education per Student) as a justification for the increase of the resource contribution for the educational policies, together with the fragility of the discourse on the destination of new sources to the education, a priori, taxes of of the Union's competence.In addition, it addresses the difficulties of the CAQ in establishing itself as a mechanism for passing on resources for the maintenance and development of education. While on the one hand the historical role of the CAQ in the expansion of resources for education is undeniable, on the other hand it has not been developed methodologically to print the qualitative assumptions of the indicator to the policy of funds. In sum, it is shown that other factors are more relevant in the division of costs than the student. New metrics for transfer of resources would allow the incorporation of guidelines in the fund structure, inducing practices of incentive to open classes and increase the time of the school day. 
Keywords: Education Financing. Fundef. Fundeb. Student-Quality Cost

\section{LISTA DE TABELAS}

Tabela 1 - Resultado financeiro negativo das administrações municipais com até 5 mil habitantes. Brasil, 2010

Tabela 2 - Resultado financeiro positivo das administrações municipais com mais de 100 mil habitantes. Brasil, 2010

Tabela 3 - População residente por grupos de idade, Brasil, 2001 - 2015

Tabela 4 - Taxa de atendimento bruta, ensino público e privado, da população em idade escolar, Brasil, 2007 - 2015

Tabela 5 - Taxa de participação das matrículas na educação básica por dependência administrativa e etapa de ensino, Brasil, 2007 - 2015

Tabela 6 - Variação da receita anual das redes estaduais com o Fundeb, 2007 - 2018

Tabela 7 - Participação das matrículas acima da idade adequada em relação ao total de cada etapa de ensino, Unidade Federativa, 2015

Tabela 8 - Valor anual por aluno do Fundeb nas séries iniciais do ensino fundamental na zona urbana, 2015

Tabela 9 - Matrículas, estabelecimentos educacionais, turmas e número de alunos por turma na educação básica. Brasil, 2007 -2017

Tabela 10 - Diferença entre os fatores de ponderação por duração da jornada escolar segundo etapa de ensino, Funbed 2018

Tabela 11 - Salário Base dos Profissionais do Magistério com Licenciatura Plena, fevereiro de 2016

Tabela 12 - Número de alunos por turma, jornada semanal e valor do CAQi segundo etapas e modalidade de ensino, 2005

Tabela 13 - Plano Referencial de Cargos e Salários do CAQi

Tabela 14 - Participação dos Insumos por Etapa de Ensino na formação CAQi

Tabela 15 - Participação do CAQi no PIB per capita segundo a etapa de ensino

Tabela 16 - Regra de transição para contabilização das despesas com inativos, Prefeitura Municipal de São Paulo, 2015-2017

Tabela 17 - Método de apropriação de custos por etapa de ensino das despesas de pessoal, Secretaria Municipal da Educação, 2015

Tabela 18 - Matrículas, turmas, jornada semanal e alunos que utilizam o transporte escolar, por etapa de ensino. Rede Municipal de São Paulo, 2015

Tabela 19 - Tabela de referência de custos por absorção segundo etapas de ensino

Tabela 20 - Valores liquidados com aposentadorias e pensões apropriados em MDE, Prefeitura Municipal de São Paulo, 2015-2017

Tabela 21 - Valores liquidados com obrigações e contribuições patronais Prefeitura Municipal de São Paulo, 2015-2017 
Tabela 22 - Subsídio ao sistema de transporte referente aos estudantes segundo etapa de ensino. Prefeitura Municipal de São Paulo, 2015

Tabela 23 - Valores liquidados segundo finalidade, Secretaria Municipal de Educação, 2015

Tabela 24 - Despesas assistenciais, culturais e esportivas segundo insumos detalhados Secretaria Municipal de Educação, 2015

Tabela 25 - Valores liquidados dos gastos com finalidade educacional segundo categoria econômica, Secretaria Municipal de Educação, 2015

Tabela 26 - Valores liquidados com gastos educacionais de pessoal, Secretaria Municipal de Gestão, 2015

Tabela 27 - Valores liquidados de insumos segundo forma de aplicação no ensino, Secretaria Municipal de Educação, 2015

Tabela 28 - Resumos do gasto com manutenção e desenvolvimento do ensino, Secretaria Municipal de Educação e outros órgãos, 2015

Tabela 29 - Análise comparada da participação dos insumos na definição dos custos com manutenção e desenvolvimento do ensino na rede municipal direta de São Paulo em relação ao CAQi, 2015 


\section{LISTA DE QUADROS E GRÁFICO}

Quadro 1 - Composição de receitas do FUNDEF e FUNDEB por esfera administrativa 34

Quadro 2 - Relacionamento: gasto, investimento, custo e despesa 89

Quadro 3 - Contabilidade governamental x contabilidade de custos: correspondência $\begin{array}{ll}\text { terminológica } & 90\end{array}$

Quadro 4 - Comparativo de gastos informados com educação infantil e ensino Fundamental

Quadro 5 - Conceito de custos aplicados à manutenção e desenvolvimento do ensino, Município de São Paulo, 2015

Gráfico 1 - Gasto público social por políticas de governo em \% do PIB 1995,2005 e 2010 


\section{LISTA DE ABREVIATURAS E SIGLAS}

ADCT Ato de Disposições Constitucionais Transitórias

ALESP Assembleia Legislativa do Estado de São Paulo

ANFOPE Associação Nacional pela Formação dos Profissionais da Educação

Anresc Avaliação Nacional do Rendimento Escolar

APEOESP Sindicato dos Professores do Ensino Oficial do Estado de São Paulo

BRICS Brasil, Rússia, Índia, China e África do Sul

CAQ Custo Aluno-Qualidade

CAQi Custo Aluno-Qualidade inicial

CEB Câmara de Educação Básica

CEU Centros de Educação Unificado

CFE Conselho Federal de Educação

CGT Central Geral dos Trabalhadores

CLT Consolidação das Leis Trabalhistas

CNBB Conferência Nacional dos Bispos do Brasil

CNE Conselho Nacional da Educação

CNI Confederação Nacional da Indústria

CNTE Confederação Nacional dos Trabalhadores em Educação

CONAE Conferência Nacional de Educação

CONSED Conselho Nacional de Secretários de Educação

CRUB Conselho de Reitores das Universidades Brasileiras

CUT Central Única dos Trabalhadores

DIEESE Departamento Intersindical de Estatística e Estudos Socioeconômicos

DF Distrito Federal

DRU Desvinculação das Receitas da União

EJA Educação de Jovens e Adultos

Enejas Encontros Nacionais de Educação de Jovens e Adultos

FINBRA Finanças do Brasil

Fineduca Associação Nacional de Pesquisa em Financiamento da Educação

FNDE Fundo Nacional de Desenvolvimento da Educação

FNE Fórum Nacional da Educação 
FPM Fundo de Participação dos Municípios

Fundef Fundo de Manutenção e Desenvolvimento do Ensino Fundamental e Valorização do Magistério

Fundeb Fundo de Manutenção e Desenvolvimento da Educação Básica e Valorização do Magistério

IBGE Instituto Brasileiro de Geografia e Estatística

ICMS Imposto sobre a Circulação de Mercadorias e Serviços

Ideb Índice de Desenvolvimento da Educação Básica

Ipea Instituto de Pesquisa Econômica Aplicada

INEP Instituto Nacional de Estudos e Pesquisas Educacionais Anísio Teixeira

INPC Índice Nacional de Preços ao Consumidor

IPIexp Imposto sobre Produtos Industrializados, proporcional às exportações

IPTU Imposto sobre a Propriedade Territorial e Urbana

IPVA Imposto sobre a Propriedade de Veículos Automotores

IRRF Imposto de Renda Retido na Fonte

ISS Imposto sobre Serviço de Qualquer Natureza

ITBI Imposto sobre a Transmissão de Bens Imóveis

ITCMD Imposto de Transmissão Causa Mortis e Doação

ITR Imposto sobre a Propriedade Territorial Rural

LDB Lei de Diretrizes e Bases da Educação Nacional

LOA Lei Orçamentária Anual

LDO Lei de Diretrizes Orçamentárias

MDE Manutenção e Desenvolvimento da Educação

MEC Ministério da Educação

NGP Nova Gestão Pública

OAB Ordem dos Advogados do Brasil

OCDE Organização para a Cooperação e Desenvolvimento Econômico

PCdoB Partido Comunista do Brasil

PDDE Programa Dinheiro Direto na Escola

PDE Plano de Desenvolvimento da Educação

PMSP Prefeitura Municipal de São Paulo

PNE Plano Nacional de Educação

PNAD Pesquisa Nacional de Amostra por Domicílios 
PNLD Programa Nacional do Livro Didático

PNBE Programa Nacional Biblioteca da Escola

PPA Plano Plurianual

PT Partido dos Trabalhadores

RREO Relatório Resumido de Execução Orçamentária

PTRF Programa de Transferência de Recursos Financeiros

SAEB Sistema Nacional de Educação Básica

SBPC Sociedade Brasileira para o Progresso da Ciência

SENAC Serviço Nacional de Aprendizagem Comercial

SENAI Serviço Nacional de Aprendizagem Industrial

SESI Serviço Social da Indústria

SIC Sistema de Informação de Custos do Governo Federal

SIOPE Sistema de Informações sobre Orçamentos Públicos em Educação

SME Secretaria Municipal de Educação

TAPS Transferências para Assistência Social, Previdência e Subsídios

UNDIME União Nacional dos Dirigentes Municipais de Educação

UNESCO Organização das Nações Unidas para a Educação, a Ciência e a Cultura

UNICEF Fundo das Nações Unidas para a Infância 


\section{SUMÁRIO}

1 INTRODUÇÃO

2 OBJETIVOS E METODOLOGIA DO ESTUDO

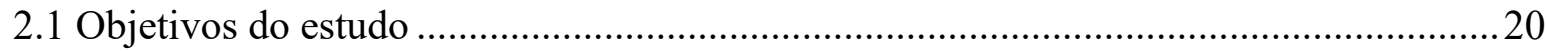

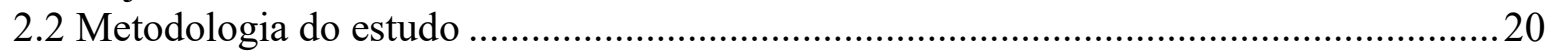

3 DO DIREITO SIMBÓLICO DAS VINCULAÇÕES DE IMPOSTOS PARA MANUTENÇÃO E DESENVOLVIMENTO DE ENSINO NAS CONSTITUIÇÕES NACIONAIS AO DIREITO INSTRUMENTAL NA IMPLEMENTAÇÃO DA POLÍTICA DE FUNDOS

3.1 As vinculações de impostos para manutenção e desenvolvimento de ensino ..................23

3.2 Fundo de Manutenção e Desenvolvimento do Ensino Fundamental e de Valorização do

Magistério - Fundef.

3.3 Fundo de Manutenção e Desenvolvimento da Educação Básica e de Valorização dos

Profissionais da Educação - Fundeb.

3.4 Análise crítica da política de fundos na educação básica: recursos destinados ao Fundeb

3.5 Análise crítica da política de fundos na educação básica: recursos distribuídos pelo

Fundeb

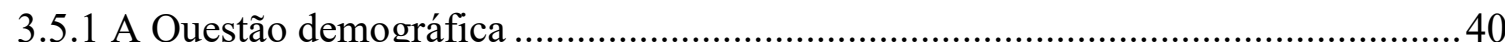

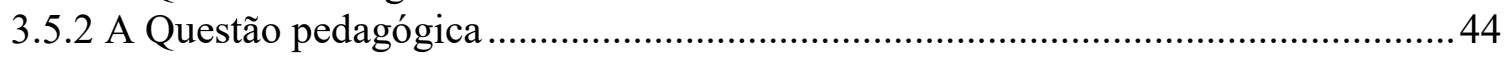

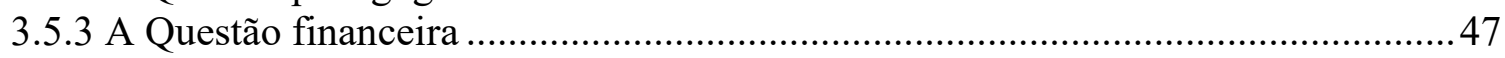

3.5.4 Distorção no cálculo de ensino em tempo integral ..................................................49

4 O EMBATE SOBRE QUALIDADE DA EDUCAÇÃO: AS ORIGENS DO CUSTO

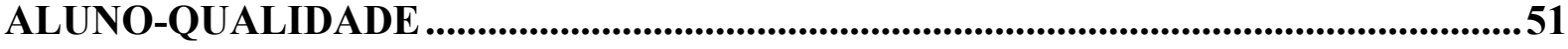

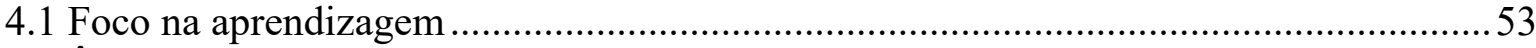

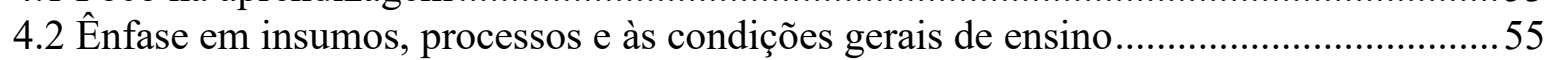

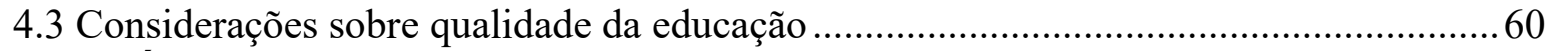

5 A RETÓRICA SOBRE AS FONTES DE FINANCIAMENTO DO CUSTO ALUNO

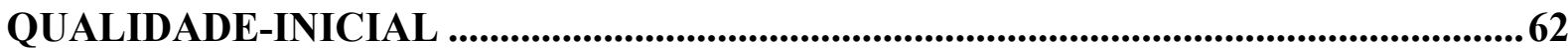

5.1 Baixo esforço da União para ampliação de recursos .....................................................6 63

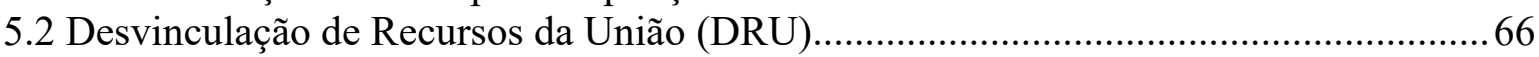

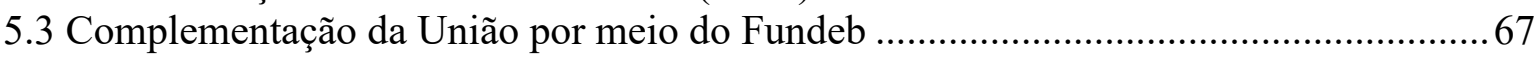

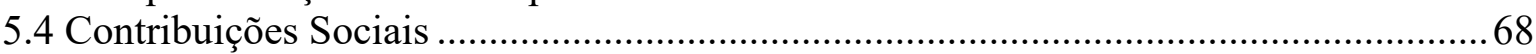

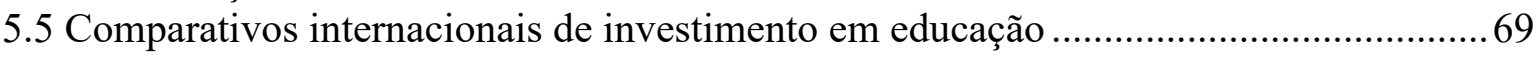

5.6 Enfrentamento das desigualdades regionais do país................................................ 71

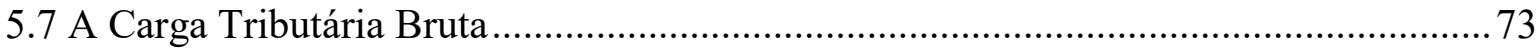

5.8 Considerações sobre a ampliação da participação da União no financiamento da política educacional

6 O CAQI ENQUANTO POLÍTICA PÚBLICA: COMPOSIÇÃO DO CAQI EM PERSPECTIVA COMPARADA AO CUSTO ALUNO DA REDE MUNICIPAL DE SÃO

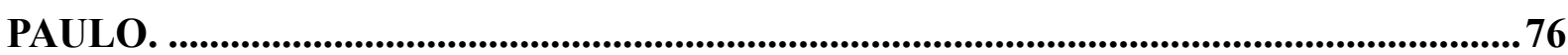

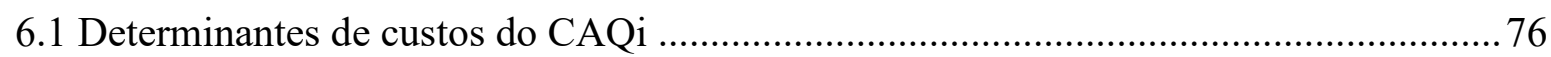

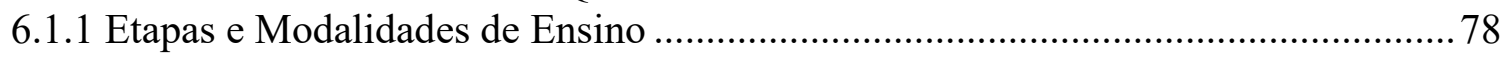

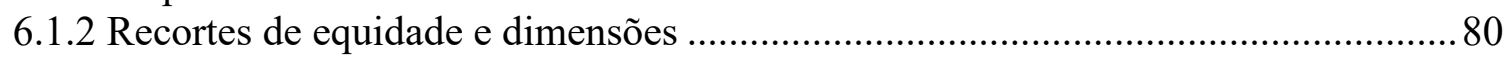

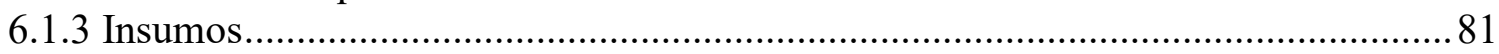

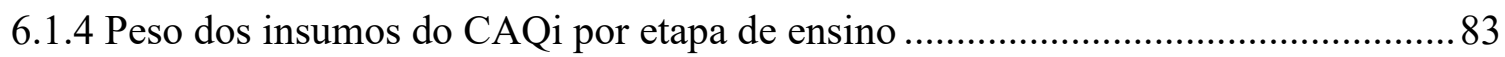

6.2 Determinantes de custos na rede municipal de São Paulo ............................................ 85 
6.2.1 Legislação municipal sobre manutenção e desenvolvimento do ensino 85

6.2.2 Metodologia para análise de custos na cidade de São Paulo

6.2.3 Análise de custos com manutenção e desenvolvimento do ensino por etapa de ensino.

7. CONSIDERAÇÕES FINAIS E PROPOSIÇÕES

REFERÊNCIAS 120

ANEXO A - CATEGORIAS PARA ANÁLISE DE CUSTOS DA REDE MUNICIPAL DE SÃO PAULO 


\section{INTRODUÇÃO}

Esta dissertação discorre críticas às políticas públicas educacionais constituídas pelo estado brasileiro na maioria das suas páginas, mas nenhum argumento supera o avanço do sistema de ensino do país nos últimos 100 anos. Em 1920, o analfabetismo atingia 69,9\% da população e a taxa de escolarização da população de 5 a 19 anos era de 9,0\%, no início da década de 70 , a taxa de escolarização era de $53,72 \%$ da população em idade escolar e em 2013 a taxa de escolarização encontrava-se no patamar de $98,8 \%$ da população de 5 a 17 $\operatorname{anos}^{1}$. A taxa de escolarização não é o melhor indicador para analisar o aprendizado dos estudantes ou a condição dos prédios escolares, mas as políticas educacionais não são constituídas apenas de refinamentos metodológicos.

O marco inicial deste trabalho ocorreu no dia 12 de junho de 2015, data de encerramento da maior $^{2}$ greve de professores do estado de São Paulo. Após 92 dias de paralisação e nenhuma sinalização de abertura de uma nova rodada de negociação os trabalhadores encerraram o movimento grevista sem a conquista do reajuste salarial. A estratégia de enfrentamento do governo estadual havia logrado êxito, o desgaste dos professores e do sindicato da categoria abriria caminho para o avanço de uma abrupta alteração da rede estadual de ensino nos meses seguintes.

No final de setembro daquele ano o governo do estado de São Paulo anunciou uma reestruturação na rede de escolas paulistas que impactaria de 1 a 2 milhões de alunos, a proposta de reorganização consistia em transformar escolas que atendiam tanto o ensino fundamental como ensino médio em escolas com ciclo único (séries iniciais do ensino fundamental, séries finais do ensino fundamental ou ensino médio) $)^{3}$.

Um mês após o anúncio da reestruturação o governo realizou uma coletiva de imprensa na qual reconheceu que seriam fechadas 94 escolas ${ }^{4}$. A confirmação desencadeou

\footnotetext{
${ }^{1}$ Pesquisa Nacional por Amostra de Domicílio - PNAD 2013/IBGE

2 ARAÚJO, Glauco. Professores de SP anunciam fim de greve após 3 meses de paralisação. Portal de notícias G1, São Paulo, 12 de jun 2015. Disponível em < http://g1.globo.com/sao-paulo/noticia/2015/06/professoresestaduais-parados-ha-3-meses-decidem-pelo-fim-de-greve.html > Acesso em: 10 dez. 2018.

${ }^{3}$ MONTEIRO. André. SP vai transferir mais de 1 milhão de alunos para dividir escolas por séries. Folha de São Paulo, 23 set. 2015. Disponível em < https:/www1.folha.uol.com.br/educacao/2015/09/1685232-sp-vaitransferir-mais-de-1-milhao-de-alunos-para-dividir-escolas-por-series.shtml > Acesso em: $10 \mathrm{dez} 2018$.

${ }^{4}$ GUILHERME, Paulo. Veja a lista das 93 escolas da rede estadual de SP que serão fechadas. Portal de notícias G1. 28 nov. 2015. Disponível em: < http://g1.globo.com/sao-paulo/noticia/2015/10/veja-lista-das-94-escolas-darede-estadual-de-sp-que-serao-fechadas.html > Acesso em: 10 dez. 2018.
} 
uma série de protestos, e em menos de duas semanas mais de 200 escolas foram ocupadas ${ }^{5}$ por estudantes contrários à medida. A Secretaria de Educação negou durante todo o processo que se tratava de uma medida financeira, contudo em nenhum momento apresentou os referenciais pedagógicos que justificavam a reorganização das escolas. Após 42 dias do anúncio do projeto o governador do estado, Geraldo Alckmin, suspendeu a medida e o então Secretário Estadual de Educação, Herman Voorwald, pediu demissão do cargo.

Nas semanas seguintes surgiram teses sobre a organização dos estudantes: análises de discurso, formas de comunicação, espontaneidade e autonomia do movimento, dentre outras. O movimento contra o fechamento de escolas se espalhou para o país no ano posterior, incorporando outras pautas, inclusive o repúdio à proposta de emenda constitucional que estabelecia teto de gastos públicos ${ }^{6}$. Entretanto, nenhuma pauta foi tão poderosa como a rejeição ao fechamento de escolas, o simbolismo de uma escola fechada tomou conta da agenda pública e os argumentos dos representantes do governo não prosperaram.

$\mathrm{Na}$ época o portal de notícias G1 entrevistou uma série de pessoas que participavam ou apoiam o movimento expondo algumas dúvidas sobre o fechamento de escolas, a ver:

Como vai ficar a superlotação das salas e a qualidade do ensino? Cecília Karina dos Santos Assis, 15 anos, aluna, E. E. Padre Saboia de Medeiros.

Por que não se abrem novas escolas e, sim, fechando as que têm? Por que também não aumenta a qualidade das escolas, tanto estrutural quanto de ensino? Vicente Ribeiro Loiola Júnior, pai e funcionário de escola estadual.

Como a Secretaria [de Educação] acha que vai melhorar a educação fechando salas de aula e demitindo mais professores?" Marcos Kauê, presidente União Municipal dos Estudantes Secundaristas de SP (PINHO, 2015)

A melhoria da qualidade do ensino associado a novas práticas pedagógicas, $\mathrm{o}$ aproveitamento da unidade escolar para ampliação do currículo, o aumento da jornada dos alunos na escola e a redução do número de alunos por turma era o discurso alternativo ao fechamento de escolas.

Este estudo caracteriza a ação de fechamento de escolas em duas dinâmicas: conjuntural e estrutural. A primeira credita aos representantes do governo estadual de São Paulo a escolha do momento e da forma de realização do processo de fechamento de turmas e escolas. A segunda

\footnotetext{
${ }^{5}$ G1 São Paulo. Ocupações, atos e polêmicas: veja histórico da reorganização escola. Portal de notícias G1, 04 dez. 2015. Disponível em: < http://g1.globo.com/sao-paulo/escolas-ocupadas/noticia/2015/12/ocupacoes-atos-epolemicas-veja-historico-da-reorganizacao-escolar.html > Acesso em 10 dez. 2018.

${ }^{6}$ ROSSI, Marina. PEC 241: Com quase 1.000 escolas ocupadas no país, ato de estudantes chega a SP. EI País Brasil, 25 out. 2016. Disponível em:

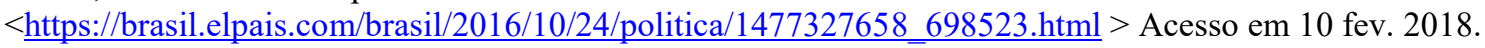


interpreta o cerne da questão que leva ao fechamento de escolas, causas que estão fora da governabilidade dos entes estaduais e municipais, sendo oriundas da regulação em âmbito federal. Para investigação da dinâmica estrutural o trabalho refaz o histórico do financiamento da educação básica brasileira, das vinculações constitucionais com manutenção e desenvolvimento do ensino (MDE) à política de fundos, tanto as formas de composição de recursos dos fundos como a estrutura institucional para distribuição dos recursos vinculados.

O repasse de recursos atrelado ao número de matrículas é observado em três perspectivas: a demográfica, a pedagógica e a financeira. A análise conjunta das três questões aponta que o formato de regulação nacional, decorrente da política de fundos, induz ao fechamento de turmas e escolas.

$\mathrm{O}$ estudo prossegue com a averiguação da principal alternativa à política de fundos debatida ao longo da última década, o Custo Aluno-Qualidade inicial (CAQi), métrica que associa parâmetros qualitativos para o financiamento da educação. Para tanto, dois caminhos são percorridos, a avaliação do indicador como instrumento de pressão para ampliação da aplicação de recursos nas políticas educacionais e como regra de repasse de recursos para garantia de uma educação de qualidade.

Além desta introdução o trabalho conta com seis capítulos. O segundo apresenta os objetivos e as definições metodológicas a cerca deste trabalho, em especial, os referenciais quantitativos na avaliação do formato de composição das receitas do Fundo de Manutenção e Desenvolvimento da Educação Básica e Valorização do Magistério (Fundeb), na utilização dos indicadores educacionais para desvendar as implicações da estrutura de repasse de recursos por aluno e na análise comparada da matriz de custos do CAQi em relação aos custos com manutenção e desenvolvimento do ensino da rede municipal de São Paulo.

O terceiro capítulo demarca a evolução do direito simbólico das vinculações de impostos à manutenção e desenvolvimento de ensino nas constituições nacionais ao direito instrumental na implementação da política de fundos. Após revisão bibliográfica sobre o histórico de constituição dos fundos realiza-se análise sobre os limites do atual sistema de financiamento, tanto referente à captação como da distribuição de recursos.

Uma vez detalhados os pontos críticos do Fundeb, adentra-se no seu possível substituto. O terceiro capítulo aborda o embate sobre as concepções de qualidade da educação, remontando tanto as origens do Custo Aluno-Qualidade, como a ascensão do conceito nas principais arenas de debate público da educação nacional.

O quarto capítulo recai sobre o maior ponto crítico do CAQi, a sua viabilidade em termos financeiros. Para tanto, o capítulo reúne os principais elementos em defesa da 
viabilidade do CAQi, em especial, a defesa de que a União deveria aportar os recursos necessários para sua implementação e expõe as divergências sobre a capacidade do ente arcar, exclusivamente, com o aumento expressivo da sua contribuição para educação básica.

No quinto capítulo a investigação concentra-se nos parâmetros utilizados para cálculo do CAQi e aborda as limitações do indicador de se transformar em uma política pública. Visando completar o percurso exploratório proposto a pesquisa examina o resultado da alocação de custos da rede municipal de ensino de São Paulo em relação à matriz do Custo Aluno-Qualidade inicial, considerando as diferenças de custos estimados em perspectiva de qualidade e os custos apurados na rede de ensino.

O último capítulo a título de considerações finais traz uma reflexão sobre os avanços e limites da política de fundos, reflete sobre a importância política do CAQi no aumento dos recursos assegurados para as políticas nas políticas educacionais, ressalta as dificuldades na produção de pesquisas em âmbito nacional que mensurem os custos com o sistema educacional e aborda as fragilidades metodológicas na indução de um sistema de educação referenciado em critérios qualitativos. 


\section{OBJETIVOS E METODOLOGIA DO ESTUDO}

\subsection{Objetivos do estudo}

\section{Objetivo geral}

Problematizar a forma de distribuição dos recursos vinculados à manutenção e desenvolvimento do ensino para os estados e municípios no seu princípio base, que vigorou com o Fundo de Manutenção e Desenvolvimento do Ensino Fundamental e Valorização do Magistério (Fundef) que financiava o ensino fundamental, o Fundeb, que financia a educação básica (educação infantil, ensino fundamental e o ensino médio) e está na essência do Custo Aluno-Qualidade inicial, que é proposto para educação básica, a distribuição dos recursos segundo o número de matrículas.

\section{Objetivos específicos}

1. Identificar disparidades entre os entes federativos na composição de receitas do Fundeb.

2. Avaliar o fechamento de turmas e escolas frente às normas de regulação federal.

3. Observar o desempenho do CAQi em dois aspectos: i) como instrumento de pressão para ampliação do investimento em educação, e; ii) como regra de repasse de recursos para garantia de uma educação de qualidade.

4. Realizar análise sobre as possibilidades de ampliação do financiamento da educação, em especial, o aumento da participação da União;

5. Analisar a validade da matriz de insumos do CAQi em relação à rede de ensino municipal de São Paulo, que aplica valores similares aos estimados pelo indicador.

\subsection{Metodologia do estudo}

A priori realiza-se revisão bibliográfica sobre financiamento da educação brasileira, compreendendo a análise de artigos e documentos, associados aos dados quantitativos sobre finanças municipais e a dinâmica recente sobre os principais indicadores educacionais. É notória a necessidade de compreensão da atual estrutura normativa sobre o financiamento da educação, a análise documental para construção do referencial histórico-normativo sobre a 
temática estará apoiada nas disposições da Constituição Federal de 1988, na Lei de Diretrizes e Bases da Educação Nacional (LDB), nas legislações dos fundos (Fundef e Fundeb) e em normas correlatas. Para além da análise documental o trabalho possui reflexões oriundas da observação participante, em que May (2001) conceitua como:

$\mathrm{O}$ processo no qual um investigador estabelece um relacionamento multilateral e de prazo relativamente longo com uma associação humana na sua situação natural com o propósito de desenvolver um entendimento científico daquele grupo (May, 2001: 177).

O procedimento se insere em um conjunto de práticas e representações mais densas, que permite ao pesquisador uma experiência mais apurada do objeto de pesquisa, devido a incursões constantes com os atores determinantes da pesquisa.

De janeiro de 2012 a novembro de 2015 este pesquisador ocupou o cargo de assessor técnico no Departamento Intersindical de Estatística e Estudos Socioeconômicos (DIEESE) na subseção do Sindicato dos Professores do Ensino Oficial do Estado de São Paulo (APEOESP) em que lhe incumbia a assessoria da diretoria da entidade sindical sobre: i) finanças e orçamento do estado de São Paulo; ii) política salarial, carreira e formação dos professores da rede estadual; iii) análise dos indicadores educacionais no estado de São Paulo, e; iv) diagnóstico do emprego no setor público.

Os principais espaços de participação sobre as políticas educacionais eram: i) as rodadas de negociação coletiva com o governo estadual e prefeituras; ii) os grupos de trabalho para elaboração de planos de carreira municipais; iii) a Comissão Paritária da Carreira dos Profissionais do Magistério do Estado de São Paulo ${ }^{7}$; iv) o Conselho de Acompanhamento e Controle Social do Fundeb do estado de São Paulo; v) as etapas preparatórias da Conferência Nacional da Educação 2014; vi) o Fórum Estadual de Educação de São Paulo; vii) as audiências públicas na Assembleia Legislativa do Estado de São Paulo (ALESP) e na Câmara Municipal de São Paulo; viii) as reuniões da Diretoria Executiva da APEOESP; ix) as reuniões do Conselho de Representantes da APEOESP; $x$ ) as reuniões da Diretoria Colegiada Estadual da APEOESP, e; xi) as assembleias de professores da APEOESP.

Sobre este tipo de participação Proença (2007) afirma:

Diferentemente da entrevista, na observação participante o pesquisador vivencia pessoalmente o evento de sua análise para melhor entendê-lo, percebendo e agindo diligentemente de acordo com as suas interpretações daquele mundo; participa nas relações

\footnotetext{
${ }^{7}$ BRASIL. Resolução SE n. 60, de 30 de agosto de 2011. Instituiu a Comissão Paritária, com a finalidade de propor critérios e procedimentos para o sistema vigente de progressão de integrante do Quadro do Magistério. São Paulo, SP, Ago 2011.
} 
sociais e procura entender as ações no contexto da situação observada. As pessoas agem e dão sentido ao seu mundo se apropriando de significados a partir do seu próprio ambiente (PROENÇA, 2007, p. 9).

Como o objeto de estudo desta pesquisa trata das normas relativas ao financiamento do ensino existe um distanciamento dos eventos pesquisados. A observação participante equivale a um conjunto expressivo de interpretações sobre as políticas educacionais, não é objeto deste trabalho interpretações, sociológicas e antropológicas, referente aos partícipes, dito de outro modo, o saber coletivo destes espaços de vivência se expressa ao longo do trabalho, mas não há observação sobre o comportamento dos envolvidos.

A análise documental e a observação participante se associam aos métodos quantitativos, que são apresentados em três ocasiões: i) na análise dos recursos destinados ao Fundeb; ii) na distribuição dos recursos do Fundeb, e; iii) na mensuração dos custos com manutenção e desenvolvimento do ensino na rede municipal de São Paulo.

Para interpretação do impacto da política de fundos nas receitas dos entes municipais utiliza-se como aporte teórico o trabalho de Limonti, Peres e Caldas (2011), o trabalho dos autores sobre o Fundeb no estado de São Paulo serve como referência para expansão a todos os estados e municípios do país. As informações sobre impostos e transferências dos entes municipais do exercício de 2010 são oriundas da base de dados do FINBRA (Finanças do Brasil), da Secretaria do Tesouro Nacional.

O segundo recorte quantitativo ocorre por meio da análise de dados: i) indicadores educacionais, sendo número de matrículas, estabelecimentos educacionais, turmas, alunos por turma, taxa de atendimento bruta e taxa de distorção idade série, tendo como referências os dados do Fundo Nacional de Desenvolvimento da Educação (FNDE) e do Instituto Nacional de Estudos e Pesquisas Educacionais Anísio Teixeira (INEP); ii) demográficos, os dados populacionais coletados por meio da Pesquisa Nacional de Amostra por Domicílios (PNAD), e; iii) financeiros, as portarias interministeriais publicadas para orientar a execução do Fundeb.

Os métodos utilizados na terceira abordagem são mais densos, do livro "Sistema de informação de custo, diretrizes para integração ao orçamento público e à contabilidade governamental” de Nelson Machado (2005) se elege os critérios para identificar os custos com manutenção e desenvolvimento do ensino na rede municipal de São Paulo, por meio da execução orçamentária da administração municipal, referente ao exercício de 2015. Além da descrição das escolhas metodológicas elucidadas na seção 6.2.2 e nos anexos A e B, empregase o estudo das classificações orçamentárias de Fabrício Augusto de Oliveira (2007), mais 
precisamente o capítulo III, “Os gastos públicos: classificação e determinantes” para categorização dos gastos por custeio direto.

\section{DO DIREITO SIMBÓLICO DAS VINCULAÇÕES DE IMPOSTOS PARA MANUTENÇÃO E DESENVOLVIMENTO DE ENSINO NAS CONSTITUIÇÕES NACIONAIS AO DIREITO INSTRUMENTAL NA IMPLEMENTAÇÃO DA POLÍTICA DE FUNDOS}

Os efeitos da estruturação de um sistema de financiamento da educação são expressos no longo prazo, a formação e desenvolvimento de inúmeras redes de ensino é uma tarefa com alto grau de dificuldade, tendo em vista a necessidade de construção de um projeto político nacional para oferta de educação básica de qualidade, em que a diversidade e a desigualdade são traços marcantes na linguagem, na alimentação, nas formas de locomoção, no próprio acesso aos serviços de saneamento básico e energia elétrica.

Para efetivar o direito à educação o país adota duas estratégias, a primeira consiste na garantia do investimento mínimo na área educacional, o embate para vincular constitucionalmente impostos para a manutenção e o desenvolvimento do ensino perpassa todo o século XX em uma trajetória marcada por avanços e retrocessos. A segunda remonta ao início dos anos 80 com os movimentos sociais engajados em prol da redemocratização, em que a defesa pela descentralização das políticas públicas representa o aumento da participação popular em vista do enfraquecimento do poder autoritário do regime militar. Porém, na década de 90 novos contornos do ideal de descentralização emergem, muitos deles, sob forte influência das ideias de falência do Estado, e é sob estas contradições, que se inicia a fase mais expressiva do contexto de descentralização das políticas educacionais.

O capítulo trata das estratégias para efetivar o financiamento das políticas educacionais, tanto no aspecto formal, com a trajetória de vinculações constitucionais dos recursos da educação, como no aspecto instrumental, com a política de fundos: Fundef e Fundeb. Logo depois concentra as críticas na atual forma de regulação da política de fundos, seja pela composição (destinação de recursos ao Fundeb), ou pela distribuição (repartição das receitas do Fundeb com os municípios e o estado).

\subsection{As vinculações de impostos para manutenção e desenvolvimento de ensino}


Desde o Império registra-se disputa para regulamentar uma vinculação obrigatória de todos os entes da federação para a área da educação. $\mathrm{O}$ que ocorre pela primeira vez na Constituição Federal de 1934 (OLIVEIRA, 2001). Nesta constituição, entre outras coisas, ficou assegurada a gratuidade e a obrigatoriedade do ensino primário, e ainda se obteve a primeira vinculação de impostos para a educação (CURY, 2007).

$\mathrm{Na}$ época as políticas públicas sem aporte de recursos se restringiam a atos declaratórios com pouca funcionalidade, assim a vinculação representava um fator determinante para efetivação do direito. As conquistas alcançadas até o período, logo forma interrompidas com a constituição outorgada de 1937, a qual restringe os direitos assegurados, e retira a vinculação constitucional de recursos. (CURY, 2007)

Após quase uma década, a Constituição Federal de 1946 retoma parte dos princípios da Constituição de 1934, reinserindo o dispositivo de vinculação orçamentária para o financiamento da educação, e restabelecendo o ensino primário como obrigatório e gratuito (CURY, 2007).

Para Morais (1993) a importância política das leis caracteriza-se pela sua essência de mediação das relações sociais, sendo objeto e resultado da disputa entre diferentes forças sociais, e no caso das leis da área educacional, são referenciais de projetos de educação e de sociedade.

Em 1961, com a aprovação da Lei de Diretrizes e Bases da Educação Nacional, a vinculação é reafirmada junto com novos parâmetros quantitativos e qualitativos que subsidiariam a elaboração do Plano Nacional de Educação, criando-se fundos de financiamento para cada nível de ensino (CURY, 2007). No entanto, após o golpe de 1964 a Constituição Federal foi desfigurada e a vinculação para a educação retirada, apenas os municípios possuíam a obrigação de destinar vinte por cento dos impostos e transferências. Neste cenário já imperavam os atos institucionais do regime ditatorial com seu forte caráter de supressão das garantias constitucionais (OLIVEIRA, 2001).

A ausência de obrigatoriedade para aplicação de recursos ao ensino vigora até dezembro de 1983, quando se aprova a emenda Calmon, a qual prevê a vinculação dos impostos para manutenção e desenvolvimento do ensino nos três entes federativos. Isto contribui com o retorno do dispositivo constitucional em 1988, que aumenta da parte correspondente à União de treze para dezoito por cento. (CASTRO, 2001)

A vinculação foi interpretada como uma evidência da relevância das políticas educacionais, visto que existia na época de elaboração do texto constitucional a possibilidade de eliminação de todas as vinculações de receita. Para Castro (2001), esta vinculação de 
impostos para a educação foi um passo importante para assegurar a responsabilidade do Estado com a área, pois no processo constituinte

se cogitava a extinção das vinculações de impostos para despesas específicas. Dentre todas as vinculações pretendidas no Congresso Constituinte (saúde, previdência, etc.), somente essa foi aprovada, o que demonstra o grau de prioridade dado à educação na Constituição (CASTRO, 2001, p.14).

Outro incremento surgiu no Ato das Disposições Constitucionais Transitórias (ADCT), onde o artigo 60 definia que cinquenta por cento dos recursos vinculados pela Constituição Federal deveriam ser aplicados para eliminar o analfabetismo e universalizar o ensino fundamental durante os dez primeiros anos da promulgação da Constituição (OLIVEIRA, 2001).

Todavia, os questionamentos da norma constitucional logo começaram a surgir. A União defendia a interpretação de que o artigo 60 das ADCT deveria ser contabilizado de modo federativo. Para o governo federal o cumprimento do artigo englobava as três esferas, computando os gastos dos estados e municípios para efeito de aplicação dos 50\% no combate ao analfabetismo e no ensino fundamental (CASTRO, 2001). Parlamentares da oposição, entidades de classe e acadêmicos defendiam que os cinquenta por cento incidiam sobre os $18 \%$ vinculados à União. No entanto, prevaleceu a interpretação do governo federal de que o "poder público" - referindo-se aos três entes concomitantemente - arcaria com as despesas de combate ao analfabetismo e manutenção e desenvolvimento de ensino, dessa forma, os gastos da União permaneceram estáveis (CASTRO, 2001).

$\mathrm{Na}$ redemocratização os estados e municípios aumentaram sua capacidade de arrecadação, porém, as atribuições não foram descentralizadas e a oferta de serviços permanecia estagnada (REZENDE, 1997). O aumento da oferta de serviços educacionais pelos governos locais teria sido abaixo do desejado e muito direcionado ao ensino pré-escolar (RODRIGUEZ, 2001).

Rodrigues (2001) afirma que as administrações municipais utilizavam artificies contábeis que permitiam cumprir a definição constitucional sem melhorar a oferta de serviços, este seria um dos "principais problemas apontados pelos foros educacionais". A falta de uma definição consistente de quais seriam os gastos com manutenção e desenvolvimento do ensino era apresentada pela maioria dos atores políticos envolvidos como um dos principais problemas. O relatório do MEC do Balanço do primeiro ano do Fundef (BRASIL, 1999) explicita algumas das ocorrências encontradas: 
não era incomum identificar situações que caracterizavam o desvio dos recursos vinculados à educação para outros fins, como a construção de ginásios de esportes, pavimentação de ruas e até mesmo instalação de sambódromos (BRASIL, 1999, p. 3).

Considerando o apresentado pelo balanço, pode-se dizer que a indefinição dos gastos com educação, em alguns casos, fez com que aqueles que não tivessem estreita relação com a área, ganhassem contornos educacionais como estratégia para justificá-los. Se por um lado a definição de despesas com educação começa a se tornar tema vencido, com definições especificas sobre a questão, por outro o discurso da descentralização das redes de ensino entra definitivamente na pauta.

\subsection{Fundo de Manutenção e Desenvolvimento do Ensino Fundamental e de Valorização do Magistério - Fundef}

A descentralização de políticas públicas no Brasil não foi provocada pelo governo federal na época da redemocratização. Nos anos 80 , as eleições para prefeitos e governadores já eram realidade, enquanto as eleições presidenciais só iriam ocorrer em 1989, deste modo a luta contra o autoritarismo associou-se à defesa pela descentralização fazendo com que esta surgisse como forma de redemocratizar o país. Assim, a "União ficou sem defensores durante a elaboração da Constituição de 1988 e a descentralização processou-se de forma descoordenada, sem um projeto articulador". (AFFONSO, 1996).

$\mathrm{Na}$ década de 90, o governo federal assume a agenda de transparência dos gastos públicos e eficiência da gestão, institui novas regras para o financiamento do ensino público e as políticas educacionais são reorientadas com o foco no ensino fundamental, inicia-se uma descentralização vigorosa das ações na área. (GUTIERREZ, 2005)

$\mathrm{O}$ ensino fundamental ascende como etapa de ensino estratégica para $\mathrm{o}$ desenvolvimento da educação, o governo Fernando Collor avalia que a situação dramática da área educacional derivava dos baixos índices de conclusão e das altas taxas de evasão e repetência. A insuficiência de vagas não era apontada como o principal problema do sistema de ensino, o problema era oriundo da baixa qualidade da oferta. A situação de pobreza atravessada por parte significativa da população brasileira é indicada como um dos fatores determinantes desta realidade, que ao ser atrelado ao discurso de falência do Estado, se conclui que o serviço público seria incapaz de promover um ensino de qualidade, com resultados semelhantes ao setor privado (CASTRO E MENEZES, 2003). A rápida passagem 
de Fernando Collor de Mello na Presidência da República, na qual a essência do governo era o discurso de modernizar o país, marcou a fase como o início da "educação espetáculo" (GUTIERREZ, 2005 apud VIEIRA).

As políticas educacionais no governo Itamar Franco não demonstravam uma coerência rigorosa, por isto, o período é visto como um momento de transição. Algumas tendências são verificadas na época como, por exemplo, a defesa da educação como promoção da modernidade; o predomínio do discurso em defesa da qualidade da educação, ao invés da prioridade ao acesso; a retomada do discurso da terceirização da gestão e; a descentralização do ensino, em contraposição à centralização (GUTIERREZ, 2005 apud VIEIRA).

A influência de organismos internacionais nas políticas educacionais já se fazia presente no início da década de 90, entretanto, no governo Itamar ainda havia a expressiva participação dos movimentos sociais no planejamento das políticas públicas. O Plano Decenal de Educação Para Todos (1993 - 2003) foi um desses exemplos, pois contou com a participação de entidades sociais ${ }^{8}$ no decorrer dos seus debates. As diretrizes aprovadas pelo Plano defendiam uma descentralização em que houvesse

participação cooperativa e integrada de todos os entes federados por intermédio do incentivo à descentralização da execução das políticas sociais para Estados e Municípios, garantindo para tal uma efetiva contrapartida no aporte de recursos financeiros pela União (GUTIERREZ, 2005, p. 138).

Todavia, o governo Fernando Henrique Cardoso surge sob uma nova composição das forças do Congresso, obtendo um congresso favorável a ele, passa a desconsiderar as propostas da sociedade civil organizada (GUTIERREZ, 2005). No governo FHC, os gestores governamentais identificaram primeiramente como problemas a serem enfrentados, a repetência, e principalmente a má gestão dos recursos financeiros, desconsiderando o diagnóstico anterior de falta de vagas, elevada evasão, e sobretudo, insuficiência de recursos. Um dos pontos fundamentais para o primeiro mandato do referido governo seria a necessidade de articular através de políticas de financiamento os entes federados. (CASTRO E MENEZES, 2003)

\footnotetext{
${ }^{8}$ De acordo com GUTIERREZ (2005) participaram dos debates o Conselho Nacional de Secretários da Educação (CONSED), a União Nacional de Dirigentes Municipais de Educação (UNDIME), o Conselho Federal de Educação (CFE), o Conselho de Reitores das Universidades Brasileiras (CRUB), a Confederação Nacional da Indústria (CNI), a Conferência Nacional dos Bispos do Brasil (CNBB), a Confederação Nacional dos Trabalhadores em Educação (CNTE), a Organização das Nações Unidas para a Educação, a Ciência e a Cultura (UNESCO), o Fundo das Nações Unidas para a Infância (UNICEF), a Associação Nacional pela Formação dos Profissionais da Educação (ANFOPE), a Ordem dos Advogados do Brasil (OAB), a Central Única dos Trabalhadores (CUT), a Central Geral dos Trabalhadores (CGT), a Sociedade Brasileira para o Progresso da Ciência (SBPC), o Serviço Social da Indústria (SESI), o Serviço Nacional de Aprendizagem Industrial (SENAI), o Serviço Nacional de Aprendizagem Comercial (SENAC), entre outras.
} 
Para isto houve a necessidade de um novo conjunto de normas para o reordenamento do financiamento do ensino fundamental: a Lei de Diretrizes e Bases da Educação Nacional (LDB) e a Emenda Constitucional 14/96, que criou o Fundo de Manutenção e Desenvolvimento do Ensino Fundamental e Valorização do Magistério (Fundef).

O primeiro projeto da LDB e o projeto-substitutivo apresentado pelo deputado Jorge Hage (PDT-BA) à Comissão de Educação, Cultura e Desportos na Câmara Federal em junho de 1990, assemelhavam-se aos princípios centrais do Estatuto da Criança e do Adolescente validado. O processo de mobilização dos movimentos sociais ocorre tanto para aprovação do Estatuto da Criança do Adolescente como para a LDB, o substitutivo do deputado Jorge Hage expressava:

tanto no sentido da ampla participação de forças sociais engajadas no debate e na defesa de interesses populares, como no espírito da lei, que além de buscar a operacionalização da garantia de direitos aos setores populares, ampliava de fato os mecanismos de participação popular no controle das políticas públicas (MANCILLA, 2006, p. 9).

No entanto, com a ascensão da coalização de centro direita em 1995, o projeto inicial com o apoio dos movimentos populares é rejeitado sob o argumento de inconstitucionalidade, conforme defendido pelo senador Darcy Ribeiro - relator da Comissão de Constituição, Justiça e Cidadania. Em seguida, o senador apresenta um substitutivo de um projeto anteriormente proposto por ele, com pequenas alterações. A proposta é encampada pelo Ministério da Educação (MEC) e em dezembro de 1996 o congresso aprova a Lei de Diretrizes e Bases da Educação Nacional encaminhada pelo senador (ZANETTI, 1997).

O governo federal afirmava que os parâmetros para planejamento e implementação de políticas públicas educacionais eram fragmentados e insuficientes. Desta maneira, a nova legislação procurava reestruturar os procedimentos e regras da gestão de recursos, com a intenção de aumentar a eficiência e a transparência nos gastos públicos com educação.

Para Zanetti (1997) a nova LDB alterou o debate sobre a questão educacional do pólo político-social para o pólo técnico-administrativo, “ignorando as determinações externas à escola e reduzindo tanto a análise quanto as soluções dos problemas educacionais brasileiros à gestão interna da escola".

Os critérios administrativos destacam-se na nova LDB, uma das conquistas seria a definição objetiva dos gastos em manutenção e desenvolvimento do ensino (MDE), o conceito é abordado nos artigos 70 e 71 . Os artigos elucidam que a utilização dos recursos destinados a "programas de atendimento alimentar, assistência médico-odontológica, farmacêutica e psicológica, e outras formas de assistência social" não constituem despesas de manutenção e 
desenvolvimento do ensino, desta maneira, se reduz as chances de desvio dos recursos da educação. Um dos pontos polêmicos da LDB foi a ausência da questão dos profissionais inativos, a qual não foi explicitada como despesa de MDE, tal ausência gerou interpretações divergentes - inclusive nos Tribunais de Contas (PERES, 2007).

Oliveira (2001) destaca que a definição precisa das despesas com transporte escolar contribuiu para assegurá-lo em localidades onde é condição objetiva para efetivação do direito à educação, e impede - ao menos legalmente - que distorções ocorressem sistematicamente.

A aprovação da Emenda Constitucional 14/96 possui o mesmo espírito da LDB, tanto é que ambas foram promulgadas no mesmo mês. Os artigos alterados da Constituição Federal foram 34, 208, 211 e 212, e o artigo 60 ADCT. As atribuições da União, dos Municípios e dos Estados são delimitadas especificamente, conforme o artigo 211:

Art. 211. A União, os Estados, o Distrito Federal e os Municípios
organizarão em regime de colaboração seus sistemas de ensino.
$\S 1^{\circ}$ A União organizará o sistema federal de ensino e o dos territórios,
financiará as instituições de ensino públicas federais e exercerá, em matéria
educacional, função redistributiva e supletiva, de forma a garantir a
equalização de oportunidades educacionais e padrão mínimo de qualidade do
ensino mediante assistência técnica e financeira aos estados, ao Distrito
Federal e aos municípios.
$\S 2^{\circ}$ Os municípios atuarão prioritariamente no ensino fundamental e na
educação infantil.
$\S 3^{\circ}$ Os estados e o Distrito Federal atuarão prioritariamente no ensino
fundamental e médio.
$\S 4^{\circ}$ Na organização de seus sistemas de ensino, os Estados e os Municípios
definirão formas de colaboração, de modo a assegurar a universalização do
ensino obrigatório (BRASIL, 1988).

As definições quanto às responsabilidades da União relacionadas ao ensino fundamental são restritas às funções redistributiva e supletiva. A emenda definiu expressamente que a União não precisaria aplicar 50\% de seus gastos constitucionais na erradicação do analfabetismo e na universalização do Ensino Fundamental, estabeleceu como regra apenas o mínimo de $30 \%$. A nova redação ainda possibilitou que a União cumprisse esse percentual com outras fontes de arrecadação, inclusive com a contribuição do salárioeducação. (CASTRO, 2001)

Aos Estados e Municípios criou-se a obrigatoriedade desses entes alocarem $60 \%$ dos recursos vinculados no ensino fundamental e a União assumiria apenas uma função complementar, isto é, quando o valor mínimo definido nacionalmente não fosse alcançado em determinado Estado haveria complementação com recursos da União.

Para Castro (2001) a implantação do Fundef foi uma estratégia para impor uma regularização dos recursos públicos para o financiamento do ensino fundamental, e assim, 
propiciar a correção das desigualdades sociais, a transparência e o controle dos gastos públicos, melhorando a qualidade do ensino por meio da vinculação de recursos para capacitação e valorização do magistério.

A Emenda Constitucional 14/96 foi regulamentada pela Lei $n^{\circ}$ 9.424/96 e pelo Decreto $n^{0}$ 2.264/1997, os critérios essenciais para formação do fundo eram: a cesta de impostos e transferências que o compunham, a forma de distribuição dos recursos, a definição do custo mínimo nacional, o controle dos repasses e a complementação da União.

O Fundef era formado por $15 \%$ da contribuição de Estados, do DF e dos Municípios, dos seguintes impostos e transferências constitucionais: Fundo de Participação dos Estados (FPE); Fundo de Participação dos Municípios (FPM); Imposto sobre Circulação de Mercadorias e Serviços (ICMS); Imposto sobre Produtos Industrializados, proporcional às exportações (IPIexp); e a desoneração de exportações assegurada pela Lei Complementar $n^{\circ}$ $87 / 96$.

Os fundos estaduais contariam com complementação da União quando o valor mínimo nacional por aluno não fosse alcançado. Porém, o modelo de cálculo do valor mínimo nacional somente funcionou no primeiro ano de vigência do fundo, posteriormente passou a ser definido por decreto, o que prejudicou a correção dos valores, pois se constatou que os valores instituídos por decreto se encontravam abaixo da regra anteriormente estabelecida. (DAVIES, 1999)

A distribuição dos recursos aos entes federativos era realizada automaticamente por meio do Banco do Brasil, tanto as retenções de impostos e transferências dos governos municipais e estaduais, quanto o crédito dos recursos do Fundo. Assim, toda a movimentação financeira da conta era realizada via Banco do Brasil, garantindo a transparência na aplicação de recursos e possibilitando o seu acompanhamento pelos órgãos de controle (CALEGARI, 2010). O critério de repasse era o número de matrículas no ensino fundamental das redes de ensino públicas, registradas no Censo Escolar no exercício anterior.

Um município ou estado podia apresentar uma relação positiva, negativa ou nula, em relação ao Fundef, pois o critério de repasse de recursos - o número de matrículas no ensino fundamental - não possui relação com a receita retida pelo fundo. Desta maneira, o resultado da distribuição beneficiava os entes com maior número de matrículas, independentemente da sua contribuição financeira. Este determinante provocaria o impulso da municipalização do ensino fundamental. (DAVIES, 1999)

A valorização do magistério, proposta pelo Fundef, obriga que no mínimo sessenta por cento dos recursos do fundo sejam direcionados ao pagamento de profissionais da área de 
educação em efetivo exercício, o professor e os demais profissionais que têm ocupações na área de suporte pedagógico. A lei define ainda que estados e municípios deveriam elaborar planos de carreira e de remuneração do magistério, os quais assegurariam uma remuneração adequada aos profissionais da área, fato que contribuiria para aumentar a qualidade do ensino.

$\mathrm{O}$ arcabouço legal instituído pelo fundo possibilitou maior controle e transparência dos gastos da educação, porém a nova política apresentava resultados negativos. Uma das grandes críticas ao Fundef é referente à prioridade dada ao ensino fundamental, a qual reduziu a participação dos Estados e Municípios na oferta das demais etapas de ensino da educação básica. (DAVIES, 1999)

$\mathrm{O}$ Fundef ao vincular parte dos recursos da educação às matrículas do ensino fundamental desencadeou um processo de "descentralização selvagem” deste nível de ensino, em detrimento dos outros níveis, o que provocou uma inflexão no número de vagas ofertadas na educação infantil e na educação de jovens e adultos (RODRIGUEZ, 2001).

Pinto (2008, p. 71), ao analisar o processo de municipalização das matrículas, afirma que é possível verificar que o Fundef:

pouco contribuiu para aumentar a eficiência de gestão do sistema e menos ainda a qualidade do ensino. Em geral, não houve consulta à comunidade escolar e os critérios de decisão foram essencialmente monetários: de um lado, os estados querendo reduzir seus alunos, de outro os municípios querendo ampliar suas receitas. A preocupação com a qualidade do ensino esteve, em geral, ausente em boa parte dos convênios de municipalização.

A complementação da União também foi alvo de críticas, uma vez que os recursos aportados eram insuficientes para cumprir sua função supletiva e redistributiva, pois o valor aluno-ano permanecia inferior aos custos reais da educação e divergia do cálculo aprovado em lei (DAVIES, 1999).

Independente do resultado educacional, o Fundef induziu o comportamento dos gestores públicos, sendo a estratégia de descentralização que de fato reestruturou os sistemas de ensino em âmbito nacional. A transferência de recursos segundo número de matrículas computadas no ano anterior imprimiu uma nova lógica ao sistema educacional, os dirigentes que possuíam assegurados $25 \%$ dos impostos e transferências para aplicação na sua rede de ensino, independentemente do tamanho da cobertura de atendimento, identificaram que no Fundef haveria a necessidade de expandir o acesso à educação para assegurar a entrada de recursos.

Os efeitos do mecanismo foram objeto de estudo recorrente, mas os resultados não prescreviam a alteração do referencial de recurso por aluno. As críticas concentravam-se na 
forma de distribuição de recursos, a qual desconsiderava: as demais etapas de ensino da educação básica, os custos com a educação do campo, as matrículas de jovens e adultos e da educação especial, a duração das turmas e a capacidade da União de cumprir com o preceito constitucional de atuar de forma redistributiva e supletiva para minorar as desigualdades regionais (RODRIGUEZ, 2001; PINTO, 2007; MONLEVADE, 2000 e DAVIES, 2006). Já em relação ao funcionamento do fundo houve investigação intensa sobre a participação social nos conselhos e produção frequente sobre a delimitação das despesas que poderiam ser efetuadas com os recursos do fundo. Por fim, sob o viés das finanças públicas há trabalhos que discutem o impacto da alteração do fluxo de receitas aos municípios, e por outro lado, da necessidade de ampliação de recursos para garantia de um padrão mínimo de qualidade (PINTO, 2015; BREMAEKER, 2010). Contudo, as críticas ao processo não mencionaram o mecanismo de transferência segundo matrícula, que permaneceu intacto e foi validado por todos os atores ao ser reproduzido no Fundeb.

\subsection{Fundo de Manutenção e Desenvolvimento da Educação Básica e de Valorização dos Profissionais da Educação - Fundeb}

Com o Fundeb o discurso de descentralização não possuía tanta relevância, as preocupações estavam em ampliar o escopo do fundo, estabelecer uma regra mais condizente para complementação da União, diferenciar os repasses segundo modalidades e etapas de ensino, entre outros temas. O intenso debate que precedeu a implementação do Fundeb foi marcado pela incorporação de demandas dos movimentos sociais e da academia. Todavia, o mecanismo de distribuições permaneceu o mesmo, as alterações ampliaram o escopo da política enquanto a estrutura institucional era reafirmada.

No Fundef, a União complementava os fundos estaduais que não atingissem o valor mínimo anual definido por decreto, mas devido à ausência de correção inflacionária dos valores mínimos, no último ano de vigência do Fundef apenas dois fundos estaduais receberam a complementação (Maranhão e Piauí). O novo método de cálculo da complementação da União pode ser dividido em duas etapas: volume de recursos e distribuição. O volume de recursos da complementação do Fundeb foi definido por valores fixos para os três primeiros anos de vigência do fundo, com a respectiva correção monetária, e a partir do quarto ano a União contribuiria com $10 \%$ de toda a arrecadação dos Fundebs, ou seja, a soma dos 26 fundos estaduais mais o do Distrito Federal. Portanto, não temos uma regra de valor aluno mínimo pré-definido, mas uma regra de aporte financeiro da União 
conforme a contribuição dos Estados e Municípios. Depois de definido o volume de recursos estes são distribuídos por um critério simples, mas bem efetivo. O estado que possui o menor valor aluno do Fundeb começa a receber recursos da União até atingir o valor aluno do estado seguinte, a partir desta equiparação os dois estados continuam recebendo recursos da União, este mecanismo se repete até todos os recursos da complementação da União ao Fundeb serem distribuídos. O aporte de recursos comparativamente maior do que o do Fundef possibilitou a ampliação do número de estados que receberiam recursos da União, passando de dois em 2006, com o Fundef, para nove estados em 2010, com o Fundeb.

Todavia, a mudança mais significativa ocorreu na distribuição de recursos aos Fundebs, ao considerar o número de matrículas de alunos da educação básica pública, incluíram-se as etapas da educação infantil e do ensino médio, e ainda, incorporaram-se as modalidades de educação de jovens e adultos, educação especial, educação indígena e a educação profissional para repartição dos recursos.

A inclusão da educação básica criou uma série de ponderações para distribuição dos recursos. O valor aluno anual é diferenciado por etapas, modalidades, tipos de estabelecimento e inclusive por ensino parcial e integral. Para cada ano de vigência do Fundeb novas ponderações balizam o repasse de recursos. Estas ganharam importância com o novo fundo, pois são capazes de redirecionar grande montante de recursos ao alterarem o peso relativo das matrículas, assim, as ponderações representam um instrumento de disputa que vai além da oferta de matrículas de cada ente federativo.

Além da ampliação na cobertura dos alunos da Educação Básica ocorreu também a ampliação para remuneração de todos os profissionais do magistério na educação básica pública, mantendo o dispositivo que reserva pelo menos $60 \%$ dos recursos para remuneração destes.

Outra forma de valorização profissional foi incorporada pelo fundo na nova redação do artigo 60 do ADCT criada pela Emenda Complementar n ${ }^{\circ} 53$ de 2006, a introdução do piso salarial nacional para os profissionais da educação pública, regulamentado pela Lei $\mathrm{n}^{\circ} 11.738$ de 16 de julho de 2008. Nessa lei foi determinado o piso salarial profissional de $\mathrm{R} \$ 950,00$ para uma jornada de no máximo 40 (quarenta) horas semanais, com mecanismo de reajuste anual que considera o percentual de variação do valor aluno ano mínimo nacional do Fundeb.

$\mathrm{O}$ modo de funcionamento do novo fundo não foi alterado significativamente, no entanto, algumas diferenças são destacadas, como: o aumento do volume de recursos, seja através da complementação da União seja pela extensão de impostos e transferências de 
estados e municípios, e também pela diversidade de matrículas contempladas nos variados níveis, etapas e modalidades de ensino.

Visando validar os objetivos do Fundeb, já em 2007, o governo federal operou o fundo através da medida provisória $n^{\circ} 339$, aprovada em 28 de dezembro de 2006. A Lei 11.494 foi promulgada em 20 de junho de 2007, mas para regular os pormenores do dispositivo, ainda viriam uma série de decretos e normas.

A composição dos recursos do Fundeb seguiu a estrutura do fundo anterior, e redirecionou ao fundo parte dos impostos e transferências já vinculados pela constituição federal para a manutenção e desenvolvimento do ensino. Os impostos que compunham o fundo anterior aumentaram sua participação gradativamente, de $15 \%$ para $20 \%$, e ainda entraram na base de incidência (de forma gradativa) o Imposto sobre a Propriedade Territorial Rural (ITR), o Imposto sobre a Propriedade de Veículos Automotores (IPVA) e o Imposto de Transmissão Causa Mortis e Doação (ITCMD).

Quadro 1 - Composição de receitas do FUNDEF e FUNDEB por esfera administrativa

\begin{tabular}{|c|c|c|c|c|c|}
\hline \multirow[b]{2}{*}{ Esfera } & \multirow[b]{2}{*}{ Impostos e Transfe rências } & \multirow{2}{*}{$\begin{array}{c}\text { Fundef } \\
\text { de } 1998 \\
\text { a } 2006\end{array}$} & \multicolumn{3}{|c|}{ Fundeb } \\
\hline & & & 2007 & 2008 & $\begin{array}{l}\text { A partir } \\
\text { de } 2009\end{array}$ \\
\hline \multirow{8}{*}{$\begin{array}{c}\text { Estados e } \\
\text { DF }\end{array}$} & \multicolumn{5}{|l|}{ Impostos Próprios } \\
\hline & IPVA & $\mathrm{x}$ & $6,67 \%$ & $13,34 \%$ & $20,00 \%$ \\
\hline & ITCMD & $\mathrm{x}$ & $6,67 \%$ & $13,34 \%$ & $20,00 \%$ \\
\hline & ICMS & $15,00 \%$ & $16,67 \%$ & $18,33 \%$ & $20,00 \%$ \\
\hline & \multicolumn{5}{|l|}{ Transfe rências da União } \\
\hline & FPE & $15,00 \%$ & $16,67 \%$ & $18,33 \%$ & $20,00 \%$ \\
\hline & IPI Exportação & $15,00 \%$ & $16,67 \%$ & $18,33 \%$ & $20,00 \%$ \\
\hline & $\begin{array}{l}\text { Lei Complementar 87/1996 - } \\
\text { Lei Kandir }\end{array}$ & $15,00 \%$ & $16,67 \%$ & $18,33 \%$ & $20,00 \%$ \\
\hline \multirow{12}{*}{ Municípios } & \multicolumn{5}{|l|}{ Impostos Próprios } \\
\hline & IPTU & $\mathrm{x}$ & $\mathrm{x}$ & $\mathrm{x}$ & $\mathrm{x}$ \\
\hline & ISS & $\mathrm{x}$ & $\mathrm{x}$ & $\mathrm{x}$ & $\mathrm{x}$ \\
\hline & ITBI & $\mathrm{x}$ & $\mathrm{x}$ & $\mathrm{x}$ & $\mathrm{x}$ \\
\hline & IRRF & $\mathrm{x}$ & $\mathrm{x}$ & $\mathrm{x}$ & $\mathrm{x}$ \\
\hline & \multicolumn{5}{|l|}{ Trans fe rências da União } \\
\hline & FPM & $15,00 \%$ & $16,67 \%$ & $18,33 \%$ & $20,00 \%$ \\
\hline & $\operatorname{ITR}(50 \%)$ & $\mathrm{x}$ & $6,67 \%$ & $13,34 \%$ & $20,00 \%$ \\
\hline & \multicolumn{5}{|l|}{ Trans fe rências do Es tado } \\
\hline & IPVA $(50 \%)$ & $\mathrm{x}$ & $6,67 \%$ & $13,34 \%$ & $20,00 \%$ \\
\hline & ICMS $(25 \%)$ & $15,00 \%$ & $16,67 \%$ & $18,33 \%$ & $20,00 \%$ \\
\hline & IPI-Exportação & $15,00 \%$ & $16,67 \%$ & $18,33 \%$ & $20,00 \%$ \\
\hline
\end{tabular}

Enquanto o Fundeb reparte as receitas com base em uma diferenciação teórica dos custos, sem base empírica para o resultado, em que as estimativas são criadas sem qualquer 
pressuposto analítico, aproximando mais do senso comum do que de aspectos técnicos. $\mathrm{O}$ Custo Aluno-Qualidade (CAQ) sistematizado por Carreira e Pinto (2007) apresenta um salto analítico ao equacionar o repasse de recursos segundo o custo dos insumos, as definições saem do campo abstrato para um referencial com base nos custos de uma educação de qualidade, o modelo de mensuração de despesas do CAQ será apresentado na seção 6.1. Os cálculos possuem um grau de detalhamento que poucos estudos propositivos ousaram mensurar, no entanto, todo o arcabouço técnico e teórico também é sistematizado com foco no aluno. A estrutura criada pelo Fundef, e aprimorada pelo Fundeb, é apresentada com acréscimos substanciais, mas o alicerce da repartição é conservado.

\subsection{Análise crítica da política de fundos na educação básica: recursos destinados ao Fundeb}

No artigo dos pesquisadores LIMONTI, PERES e CALDAS (2014) há identificação de um efeito negativo no Fundeb no âmbito do Estado de São Paulo, que se refere a distribuição desigual de recursos entre os municípios, concluindo que os municípios com menor porte demográfico ${ }^{9}$ em sua grande maioria apresentam perdas financeiras com o Fundeb.

Segundo os autores os municípios menores possuem uma arrecadação tributária própria baixa, decorrente do restrito território na zona urbana, da pequena capacidade de consumo das famílias e das dificuldades políticas e administrativas com arrecadação de impostos.

Deste modo, a participação dos impostos sobre propriedade, como o Imposto sobre a Propriedade Territorial e Urbana (IPTU) e o IPVA, e sobre a atividade econômica, como o Imposto sobre Serviço de Qualquer Natureza (ISS) e o ICMS, tem baixa representatividade nestes municípios. Assim, o FPM figura como a principal fonte de recurso dessas municipalidades, uma vez que, para promover o equilíbrio socioeconômico entre os entes federativos essa transferência constitucional utiliza como critério para repasse dos recursos uma relação inversamente proporcional ao tamanho dos municípios, o que proporciona aos municípios menores uma soma de recursos maior por habitante.

Neste caso quando o Fundeb retém vinte por cento do FPM para sua composição atinge mais intensamente a receita dos municípios menores. Enquanto o IPTU e ISS, impostos

\footnotetext{
${ }^{9}$ No estudo em questão municípios de menor porte demográfico foram caracterizados com uma população igual ou inferior a 5 mil habitantes.
} 
expressivos nas maiores cidades, não estão vinculados ao Fundeb, assim os pequenos municípios dependentes do FPM têm $20 \%$ da sua arrecadação retida pelo fundo, enquanto os municípios maiores em que o FPM é inexpressivo, não contribuem com as suas receitas principais.

Por outro lado, a destinação de recursos do Fundeb aos munícipios menores é pouco expressiva devido ao reduzido número de habitantes, especialmente de pessoas em idade escolar. Esse fato explica as perdas financeiras em 2009 de 138 municípios paulistas com até 5 mil habitantes, o que equivale a $86,8 \%$ das administrações municipais dessa faixa populacional no Estado de São Paulo. As perdas financeiras também poderiam ocorrer devido ao baixo oferecimento de matrículas na educação básica pelos entes locais, no entanto, tal tese não se sustenta, uma vez que, os municípios menores detêm um número de matrículas proporcionalmente superior às demais esferas, pública ou privada, nos seus territórios, e ainda atendem parcela maior da sua população em idade escolar quando comparado com as demais municipalidades.

E por fim, ao projetar um cenário hipotético na qual a educação básica estivesse universalizada no Estado de São Paulo, em que as matrículas não apresentariam mais variações expressivas, identificou-se que as perdas dos municípios menores seriam agravadas, pois o índice de municípios com até 5 mil habitantes que registrariam perdas seria de $95 \%$, ou seja, em um cenário estático em que todas as crianças e adolescentes residentes no Estado de São Paulo tivessem acesso a educação básica, as perdas financeiras atingiriam quase a totalidade dos municípios pequenos.

Perante isto, os pesquisadores afirmam que a implementação do Fundeb no Estado de São Paulo não possibilitou a equidade de condições entre os entes federativos locais como se pretendia com a criação dos fundos, pois as distorções no funcionamento prejudicam os entes mais frágeis economicamente no Estado de São Paulo.

Tendo em vista que a análise acima se refere somente ao funcionamento do Fundeb no Estado de São Paulo a presente pesquisa expandiu a utilização da metodologia para os demais 25 fundos estaduais para examinar se tal distorção é exclusiva das cidades paulistas ou se nos demais estados da federação também ocorre tal iniquidade.

Para tanto, se utilizou o banco de dados de finanças municipais da Secretaria do Tesouro Nacional, o FINBRA. Dois critérios foram utilizados para seleção do ano, considerar somente os exercícios em que o Fundeb estava em funcionamento pleno (a partir de 2009) e o outro era selecionar uma amostra com o maior número de municípios, uma vez que o banco de dados referido não continha informações da totalidade dos municípios, o exercício de 2010 
foi o mais adequado. A expansão da pesquisa para todo o país seguia o mesmo princípio da anterior, avaliar o peso do resultado do Fundeb nos entes municipais segundo tamanho da população e a capacidade de arrecadação do ente, além da comparação relativa das principais receitas dos entes e da interação com o Fundeb havia necessidade de controlar outra variável neste contexto, estados que recebem, ou não, a complementação da União. O estado de São Paulo não recebia a complementação da União, por isso, a variável não era citada no estudo de referência.

Antes de apresentar os dados em relação à separação anunciada é necessário ressaltar a diferença de participação do conjunto das redes municipais no número de matrículas na educação básica de cada estado. As redes de ensino municipais nas regiões Norte e da Nordeste possuem uma participação superior na oferta de vagas do que as redes estaduais, este peso relativo destas redes municipais é superior ao verificado nas demais regiões do país. Somado a isto, tem-se que a importância relativa do ICMS na arrecadação estadual possui um peso significativamente menor. Portanto, as relações de troca entre estado e municípios e entre os municípios são mais equânimes nessas localidades.

Há ainda mais um ponto importante, para fins de facilitar a compreensão dos dados optou-se pela divulgação do resultado por meio de duas tabelas. A apresentação dos dados municipais está ancorado nos extremos em termos de populacionais, a primeira faixa populacional de zero a 5 mil habitantes e a ultima faixa, acima de 100 mil habitantes, os dados municipais de 5,1 mil a 100 mil habitantes não confirmam ou rejeitam a hipótese de pesquisa, e por isso, não constam nas tabelas abaixo.

Dos 1.224 municípios com menos de 5 mil habitantes, apenas 156 municípios são de estados que receberam complementação da União, cerca de $12,7 \%$ do total. O estado do Amazonas não possui nenhum município com até 5 mil habitantes, no Pará há apenas um município, no Ceará e em Pernambuco são duas cidades, no Maranhão e em Alagoas são cinco municípios, depois aparecem Bahia com 9 cidades, e Paraíba e Piaú com 64 e 68 cidades, respectivamente.

Devido ao recebimento da complementação da União, reforçado pelo reduzido número de municípios com até 5 mil habitantes nestes estados, a tendência de perdas financeiras neste conjunto de municípios é inferior ao verificado no Estado de São Paulo, com 37,8\% dos municípios nesta faixa populacional registrando perdas financeiras. 
Tabela 1 - Resultado financeiro negativo das administrações municipais com até 5 mil habitantes. Brasil, 2010.

\begin{tabular}{c|c|c|cc|c|c|c}
\hline UF & $\begin{array}{c}\mathbf{N}^{0} \text { de municípios } \\
\text { com perdas do } \\
\text { FUNDEB }\end{array}$ & $\begin{array}{c}\text { Participação em } \\
\text { relação ao total } \\
\text { de municípios }\end{array}$ & $\begin{array}{c}\text { Total de } \\
\text { municípios }\end{array}$ & UF & $\begin{array}{c}\mathbf{N}^{0} \text { de municípios } \\
\text { com perdas do } \\
\text { FUNDEB }\end{array}$ & $\begin{array}{c}\text { Participação em } \\
\text { relação ao total } \\
\text { de municípios }\end{array}$ & $\begin{array}{c}\text { Total de } \\
\text { municípios }\end{array}$ \\
\hline
\end{tabular}

Estados que NÃO receberam complementação da União

\begin{tabular}{|c|c|c|c|c|c|c|c|}
\hline \multicolumn{4}{|l|}{ União } & \multicolumn{4}{|c|}{ Estados que receberam complementação da União } \\
\hline $\mathrm{SC}$ & 105 & $97,2 \%$ & 108 & $\mathrm{BA}$ & 5 & $55,6 \%$ & 9 \\
\hline GO & 83 & $91,2 \%$ & 91 & MA & 1 & $20,0 \%$ & 5 \\
\hline $\mathrm{RS}$ & 204 & $91,1 \%$ & 224 & $\mathrm{CE}$ & & $0,0 \%$ & 2 \\
\hline PR & 82 & $86,3 \%$ & 95 & $\mathrm{PE}$ & 2 & $100,0 \%$ & 2 \\
\hline MS & 6 & $85,7 \%$ & 7 & PI & 17 & $25,0 \%$ & 68 \\
\hline RO & 5 & $83,3 \%$ & 6 & PB & 34 & $53,1 \%$ & 64 \\
\hline MG & 187 & $83,1 \%$ & 225 & $\mathrm{AL}$ & & $0,0 \%$ & 5 \\
\hline SP & 120 & $80,5 \%$ & 149 & PA & & $0,0 \%$ & 1 \\
\hline MT & 28 & $77,8 \%$ & 36 & $\mathrm{AM}$ & 0 & $0,0 \%$ & 0 \\
\hline TO & 34 & $50,7 \%$ & 67 & Subtotal (II) & 59 & $37,8 \%$ & 156 \\
\hline SE & 5 & $45,5 \%$ & 11 & & & & \\
\hline $\mathrm{RN}$ & 17 & $38,6 \%$ & 44 & & & & \\
\hline RJ & 0 & - & 0 & & & & \\
\hline $\mathrm{RR}$ & 0 & - & 0 & & & & \\
\hline $\mathrm{AP}$ & 0 & $0,0 \%$ & 3 & & & & \\
\hline $\mathrm{AC}$ & 0 & $0,0 \%$ & 1 & & & & \\
\hline ES & 1 & $100,0 \%$ & 1 & & & & \\
\hline Subtotal (I) & 877 & $82,1 \%$ & 1068 & & & & \\
\hline
\end{tabular}

Total (III = I+II)

936

$76,5 \%$

1224

Fonte: FINBRA 2010

Contudo nos demais municípios com até 5 mil habitantes a taxa de municípios com registro de perdas financeiras é de $82,1 \%$, ou seja, a distorção verificada no Estado de São Paulo incide nos estados que não recebem complementação da União. O Fundeb exige dos menores municípios um esforço fiscal mais acentuado em relação aos demais municípios.

Para reforçar o desequilíbrio entre os municípios, $84,1 \%$ dos municípios com mais de 100 mil habitantes registram ganhos financeiros com o Fundeb. Portanto, a análise que evidenciou a relação de desigualdade nas cidades paulistas em relação ao funcionamento do fundo pode ser expandida aos municípios do país, enquanto a maioria dos municípios com menos de 5 mil habitantes registram perdas financeiras com o fundo, 84,1\% dos maiores municípios registra ganhos financeiros. 
Tabela 2 - Resultado financeiro positivo das administrações municipais com mais de 100 mil habitantes. Brasil, 2010

\begin{tabular}{|c|c|c|c|c|c|c|c|}
\hline $\mathbf{U F}$ & $\begin{array}{c}N^{0} \text { de municípios com } \\
\text { ganhos financeiros } \\
\text { com o FUNDEB }\end{array}$ & $\begin{array}{c}\text { Participação em } \\
\text { relação ao total } \\
\text { de municípios }\end{array}$ & $\begin{array}{c}\text { Total de } \\
\text { municípios }\end{array}$ & $\mathbf{U F}$ & $\begin{array}{c}\mathrm{N}^{\circ} \text { de municípios com } \\
\text { ganhos financeiros } \\
\text { com o FUNDEB }\end{array}$ & $\begin{array}{c}\text { Participação em } \\
\text { relação ao total de } \\
\text { municípios }\end{array}$ & $\begin{array}{c}\text { Total de } \\
\text { municípios }\end{array}$ \\
\hline \multicolumn{4}{|c|}{ Estados que NÃO receberam complementação da União } & \multicolumn{4}{|c|}{ Estados que receberam complementação da União } \\
\hline SC & 12 & $100,0 \%$ & 12 & BA & 11 & $84,6 \%$ & 13 \\
\hline GO & 8 & $88,9 \%$ & 9 & MA & 8 & $88,9 \%$ & 9 \\
\hline RS & 17 & $94,4 \%$ & 18 & $\mathrm{CE}$ & 6 & $75,0 \%$ & 8 \\
\hline PR & 14 & $87,5 \%$ & 16 & $\mathrm{PE}$ & 9 & $75,0 \%$ & 12 \\
\hline MS & 4 & $100,0 \%$ & 4 & PI & 2 & $100,0 \%$ & 2 \\
\hline MG & 25 & $86,2 \%$ & 29 & PB & 3 & $75,0 \%$ & 4 \\
\hline SP & 59 & $79,7 \%$ & 74 & $\mathrm{AL}$ & 1 & $50,0 \%$ & 2 \\
\hline MT & 3 & $75,0 \%$ & 4 & PA & 5 & $55,6 \%$ & 9 \\
\hline ES & 9 & $100,0 \%$ & 9 & $\mathrm{AM}$ & 1 & $100,0 \%$ & 1 \\
\hline RJ & 20 & $87,0 \%$ & 23 & Subtc & otal (II) & $76,7 \%$ & 60 \\
\hline SE & 1 & $50,0 \%$ & 2 & & & & \\
\hline $\mathrm{RN}$ & 3 & $100,0 \%$ & 3 & & & & \\
\hline $\mathrm{AP}$ & 2 & $100,0 \%$ & 2 & & & & \\
\hline $\mathrm{AC}$ & 0 & $0,0 \%$ & 1 & & & & \\
\hline RO & 2 & $100,0 \%$ & 2 & & & & \\
\hline TO & 2 & $100,0 \%$ & 2 & & & & \\
\hline $\mathrm{RR}$ & 1 & $100,0 \%$ & 1 & & & & \\
\hline Subtc & $\operatorname{tal}(I)$ & $84,6 \%$ & 13 & & & & \\
\hline \multicolumn{2}{|c|}{ Total (III = I+II) } & & & & 228 & $84,1 \%$ & 271 \\
\hline
\end{tabular}

Fonte: FINBRA 2010

\subsection{Análise crítica da política de fundos na educação básica: recursos distribuídos pelo Fundeb}

O mecanismo de repasse criado pelo Fundef de distribuição das receitas segundo o número de matrículas foi exitoso na indução dos gestores ampliarem o atendimento educacional das suas respectivas redes de ensino. O Fundeb utiliza o mesmo instrumento para o cálculo de distribuição de recursos e no CAQi este é o eixo para contabilização dos custos educacionais.

Esta seção elenca três questões inerentes à vinculação de repasses segundo o número de matrículas: i) demográfica, ao vincular os efeitos demográficos à estrutura de financiamento do ensino; ii) pedagógica, ao privilegiar uma forma de organização do ensino; e; iii) financeira, que prejudica o equilíbrio das contas dos sistemas de ensino. Ao final, trata sobre os métodos de apuração da educação em tempo integral para fins do Fundeb. 


\subsubsection{A Questão demográfica}

Os dados da PNAD identificam a mudança demográfica que está em curso e impacta diretamente as políticas educacionais. No período de 2001 a 2015 a variação mais acentuada ocorreu na faixa etária de até 3 anos, correspondente a creche, com redução de 18,0\%, de 14 milhões em 2001 para 11,5 milhões de pessoas em 2015. As crianças com idade escolar para frequentarem a pré-escola aparecem na sequência com queda de $17,9 \%$, redução de 1,2 milhão de pessoas. De 6 a 14 anos, idade adequada para o ensino fundamental, a queda foi de $7 \%$, a única etapa que registrou crescimento foi o ensino médio, crescimento de $2,1 \%$. Contudo, ao analisar os dados demográficos no contexto de implementação do Fundeb se verifica uma trajetória distinta. A queda do número de pessoas na educação infantil foi mais acentuada no período anterior a aplicação do Fundeb (2001 a 2007), com variações negativas de $12,3 \%$ e 9,7\%, na creche e na pré-escola, respectivamente. No período seguinte o número crianças na educação infantil continuou em queda, mais em uma velocidade menor. Por outro lado, o número de pessoas com idade adequada para o ensino fundamental cresceu em 4,9\% no período que antecedeu a criação do fundo, e foi reduzido em grande intensidade no período posterior, enquanto no primeiro momento há aumento de 1,5 milhão de pessoas, no segundo a queda de 3,5 milhão de pessoas. O ensino médio é a única etapa, em termos nacionais, que não foi impactada pela curva demográfica.

Tabela 3 - População residente por grupos de idade, Brasil, 2001 - 2015

\begin{tabular}{|c|c|c|c|c|c|c|c|c|c|}
\hline \multirow{3}{*}{ Faixa Etária } & \multicolumn{6}{|c|}{ Ano } & \multicolumn{3}{|c|}{ Variação } \\
\hline & \multicolumn{2}{|c|}{2001} & \multicolumn{2}{|c|}{2007} & \multicolumn{2}{|c|}{2015} & \multirow{2}{*}{$\begin{array}{l}2007 / \\
2001\end{array}$} & \multirow{2}{*}{$\begin{array}{l}2015 / \\
2007 \\
\end{array}$} & \multirow{2}{*}{$\begin{array}{l}2015 / \\
2001\end{array}$} \\
\hline & Núme ro & Part. & Núme ro & Part. & Núme ro & Part. & & & \\
\hline $\begin{array}{l}\text { Educação Infantil } \\
\text { (de } 0 \text { a } 3 \text { anos) }\end{array}$ & 14.089 .423 & $23,1 \%$ & 12.355 .252 & $20,6 \%$ & 11.551 .738 & $20,9 \%$ & $-12,3 \%$ & $-6,5 \%$ & $-18,0 \%$ \\
\hline $\begin{array}{l}\text { Pré-Escola } \\
\text { (de } 4 \text { a } 5 \text { anos) }\end{array}$ & 6.541 .572 & $10,7 \%$ & 5.904 .134 & $9,9 \%$ & 5.373 .270 & $9,7 \%$ & $-9,7 \%$ & $-9,0 \%$ & $-17,9 \%$ \\
\hline $\begin{array}{l}\text { Ensino Fundamental } \\
\text { (de } 6 \text { a } 14 \text { anos) }\end{array}$ & 29.974 .537 & $49,2 \%$ & 31.447 .266 & $52,5 \%$ & 27.889 .801 & $50,4 \%$ & $4,9 \%$ & $-11,3 \%$ & $-7,0 \%$ \\
\hline $\begin{array}{l}\text { Ensino Médio } \\
\text { (de } 15 \text { a } 17 \text { anos) }\end{array}$ & 10.333.209 & $17,0 \%$ & 10.164 .483 & $17,0 \%$ & 10.548 .537 & $19,1 \%$ & $-1,6 \%$ & $3,8 \%$ & $2,1 \%$ \\
\hline Total & 60.938 .741 & $100,0 \%$ & 59.871 .135 & $100,0 \%$ & 55.363 .346 & $100,0 \%$ & $-1,8 \%$ & $-7,5 \%$ & $-9,1 \%$ \\
\hline
\end{tabular}

Fonte: Microdados da Pesquisa Nacional de Amostra por Domicílio - PNAD/IBGE

A taxa de atendimento bruta da população em idade escolar considera todas as matrículas, públicas e privadas, em relação à população em idade escolar correspondente a cada etapa de ensino, taxas superiores a $100 \%$ podem ser encontradas devido ao grande número de alunos com idade superior à adequada que frequentam as unidades escolares. Em 2007, a única etapa com atendimento igual ou superior a $100 \%$ era o ensino fundamental, a 
pré-escola e o ensino médio apresentavam valores intermediários, com taxas de atendimento de $83,5 \%$ e $82,3 \%$, respectivamente. O déficit de atendimento mais elevado residia na primeira etapa de ensino, apenas $12,8 \%$ das crianças em idade adequada para creches frequentavam esta etapa de ensino.

No nono ano de implementação do Fundeb a taxa de atendimento bruta do ensino fundamental permanecia estável, acima de $100 \%$, enquanto as matrículas em creches e préescola haviam avançado consistentemente no período, taxa de $26,4 \%$ e $91,4 \%$, respectivamente. As taxas de evasão escolar no ensino médio seguraram a taxa de atendimento, reduzindo o contingente atendido em quase 300 mil alunos. Enquanto o avanço da taxa de atendimento da pré-escola ocorreu apenas pela manutenção das matrículas do período anterior, na creche as matrículas praticamente dobraram, inclusão de 1,4 milhão de crianças nas unidades escolares, por outro lado, a estabilidade do atendimento do ensino fundamental esconde uma redução de 4,1 milhões de alunos.

Tabela 4 - Taxa de atendimento bruta, ensino público e privado, da população em idade escolar, Brasil, 2007 - 2015

\begin{tabular}{l|r|r|r}
\hline Ano/Etapa de Ensino & Matrículas & $\begin{array}{c}\text { População em } \\
\text { idade escolar }\end{array}$ & $\begin{array}{c}\text { Taxa de } \\
\text { Atendimento } \\
\text { Bruta }\end{array}$ \\
\hline 2007 & & & \\
Creche & 1.579 .581 & 12.355 .252 & $12,8 \%$ \\
Pré-escola & 4.930 .287 & 5.904 .134 & $83,5 \%$ \\
Ensino Fundamental & 32.122 .273 & 31.447 .266 & $102,1 \%$ \\
Ensino Médio & 8.369 .369 & 10.164 .483 & $82,3 \%$ \\
Educação Básica & 47.001 .510 & 59.871 .135 & $78,5 \%$ \\
\hline 2015 & & & \\
Creche & 3.049 .072 & 11.551 .738 & $26,4 \%$ \\
Pré-escola & 4.923 .158 & 5.373 .270 & $91,6 \%$ \\
Ensino Fundamental & 27.931 .210 & 27.889 .801 & $100,1 \%$ \\
Ensino Médio & 8.076 .150 & 10.548 .537 & $76,6 \%$ \\
Educação Básica & 43.979 .590 & 55.363 .346 & $79,4 \%$ \\
\hline
\end{tabular}

Fonte: Sinopses Estatísticas da Educação Básica/INEP

Além das mudanças demográficas no período de 2007 a 2015 houve avanço das redes privadas de ensino, com acréscimo de 2,3 milhões de matrículas, sendo 785 mil na educação infantil e 1,5 milhão no ensino fundamental e médio. Enquanto a expansão na educação infantil contou com o apoio do poder público por meio de instituições comunitárias, confessionais ou filantrópicas sem fins lucrativos, nas etapas subsequentes o crescimento 
representava o avanço do setor sobre um contingente que nos anos anteriores era atendido pelo poder público.

A soma do efeito demográfico com a expansão da educação por estabelecimentos educacionais particulares reduziu a participação das redes estaduais na educação básica de $39,9 \%$ para $33 \%$, em especial, devido a queda de 8 pontos percentuais no ensino fundamental. O ensino nas unidades municipais cresceu $0,6 \%$ pontos percentuais, enquanto a educação privada apresentou crescimento acima de 50\%, de 12\% em 2007 para 18,1\% em 2015 (Tabela $5)$.

Tabela 5 - Taxa de participação das matrículas na educação básica por dependência administrativa e etapa de ensino, Brasil, 2007 - 2015

\begin{tabular}{l|r|r|r|r}
\hline \multirow{2}{*}{ Ano/Etapa de Ensino } & \multicolumn{4}{|c}{ Dependência Administrativa } \\
\cline { 2 - 5 } & Federal & Estadual & Municipal & Privada \\
\hline 2007 & & & & \\
Creche & $0,1 \%$ & $0,5 \%$ & $65,9 \%$ & $33,5 \%$ \\
Pré-escola & $0,0 \%$ & $3,4 \%$ & $75,6 \%$ & $20,9 \%$ \\
Ensino Fundamental & $0,1 \%$ & $35,3 \%$ & $54,7 \%$ & $9,9 \%$ \\
Ensino Médio & $0,8 \%$ & $86,5 \%$ & $2,0 \%$ & $10,7 \%$ \\
Educação Básica & $0,2 \%$ & $39,9 \%$ & $47,9 \%$ & $12,0 \%$ \\
\hline 2015 & & & & \\
Creche & $0,0 \%$ & $0,1 \%$ & $63,4 \%$ & $36,5 \%$ \\
Pré-escola & $0,0 \%$ & $1,0 \%$ & $73,9 \%$ & $25,1 \%$ \\
Ensino Fundamental & $0,1 \%$ & $27,3 \%$ & $56,3 \%$ & $16,4 \%$ \\
Ensino Médio & $1,9 \%$ & $84,4 \%$ & $0,6 \%$ & $13,0 \%$ \\
Educação Básica & $0,4 \%$ & $33,0 \%$ & $48,5 \%$ & $18,1 \%$ \\
\hline
\end{tabular}

Fonte: Sinopses Estatísticas da Educação Básica/INEP

Os dois fatores de redução de contingente de alunos, a curva demográfica e o avanço do setor privado, não eram administrados diretamente pelas redes de ensino, ambos externos à tomada de decisão do gestor público. Contudo, quando o Fundeb condiciona o repasse de recursos às matrículas da rede de ensino ele associa estes efeitos à política educacional. Ao reduzir os recursos destes entes perde-se a oportunidade de aproveitar as oscilações populacionais para implementar melhorias no ensino. O Fundeb aparenta ser um sistema fechado com variáveis controláveis, mas além dos dois fatores que interferem no contingente de matrículas do fundo citados acima, temos estágios diferentes de desenvolvimento das etapas de ensino, enquanto um ente pode aumentar a oferta de ensino em uma determinada etapa, o outro com atendimento universalizado fica preso às variáveis externas, com redução de matrículas, e consequentemente de receitas. Neste sentido as redes estaduais que possuíam 
taxas de atendimento em patamares elevados são as que mais enfrentam os efeitos desta vinculação.

O percentual de receitas do Fundeb transferidas para as redes estaduais caiu de 47,1\% em 2007 para 41,6\% em 2018, a queda de 5,5 pontos percentuais equivale a uma redução R\$ 8 bilhões em 2018. Dos 27 estados 20 registram queda na participação, entre os 6 estados com aumento da participação, encontra-se 5 estados que possuíam oferta abaixo de $30 \%$, e ainda, recebem complementação da União.

Tabela 6 - Variação da receita anual das redes estaduais com o Fundeb, 2007 - 2018

\begin{tabular}{|c|c|c|c|c|c|c|c|c|c|c|c|}
\hline \multirow{4}{*}{ UF } & \multicolumn{8}{|c|}{ Receita anual previs ta do Fundeb por ano } & \multirow{3}{*}{\multicolumn{2}{|c|}{\begin{tabular}{|c|} 
Variação 2018/ \\
2007 \\
Dependência \\
Administrativa \\
\end{tabular}}} & \multirow{4}{*}{$\begin{array}{l}\text { Variação da } \\
\text { taxa de } \\
\text { participação } \\
\text { dos estados } \\
\text { em pontos } \\
\text { percentuais }\end{array}$} \\
\hline & \multicolumn{4}{|c|}{2007} & \multicolumn{4}{|c|}{2018} & & & \\
\hline & \multicolumn{2}{|c|}{$\begin{array}{l}\text { Dependência } \\
\text { Administrativa }\end{array}$} & \multirow[t]{2}{*}{ Total } & \multirow{2}{*}{$\begin{array}{c}\% \text { de } \\
\text { receitas } \\
\text { das redes } \\
\text { estaduais }\end{array}$} & \multicolumn{2}{|c|}{$\begin{array}{c}\text { Dependência } \\
\text { Adminis trativa }\end{array}$} & \multirow[t]{2}{*}{ Total } & \multirow{2}{*}{$\begin{array}{c}\% \text { de } \\
\text { receitas } \\
\text { das redes } \\
\text { estaduais }\end{array}$} & & & \\
\hline & Municipal & Estadual & & & Municipal & Estadual & & & Municipal & Estadual & \\
\hline $\mathrm{RR}$ & 49 & 170 & 219 & $77,5 \%$ & 317 & 384 & 701 & $54,8 \%$ & $541,0 \%$ & $126,1 \%$ & $-22,7 \%$ \\
\hline $\mathrm{SC}$ & 713 & 811 & 1.524 & $53,2 \%$ & 3.237 & 2.210 & 5.447 & $40,6 \%$ & $353,8 \%$ & $172,7 \%$ & $-12,6 \%$ \\
\hline AP & 74 & 215 & 288 & $74,4 \%$ & 308 & 530 & 838 & $63,2 \%$ & $317,1 \%$ & $147,1 \%$ & $-11,1 \%$ \\
\hline SP & 5.128 & 7.240 & 12.368 & $58,5 \%$ & 17.193 & 15.781 & 32.974 & $47,9 \%$ & $235,3 \%$ & $118,0 \%$ & $-10,7 \%$ \\
\hline TO & 214 & 276 & 491 & $56,3 \%$ & 840 & 716 & 1.556 & $46,0 \%$ & $291,9 \%$ & $159,1 \%$ & $-10,3 \%$ \\
\hline $\mathrm{GO}$ & 630 & 650 & 1.280 & $50,8 \%$ & 2.558 & 1.911 & 4.469 & $42,8 \%$ & $306,1 \%$ & $194,0 \%$ & $-8,0 \%$ \\
\hline RS & 1.345 & 1.554 & 2.900 & $53,6 \%$ & 4.691 & 4.202 & 8.893 & $3 \%$ & $248,7 \%$ & $170,3 \%$ & $-6,4 \%$ \\
\hline RJ & 2.022 & 1.053 & 3.074 & $34,2 \%$ & 5.966 & 2.428 & 8.394 & $28,9 \%$ & $195,1 \%$ & $130,6 \%$ & $-5,3 \%$ \\
\hline MS & 405 & 355 & 759 & $46,7 \%$ & 1.274 & 939 & 2.214 & $42,4 \%$ & $215,0 \%$ & $164,8 \%$ & $-4,3 \%$ \\
\hline PR & 1.106 & 1.318 & 2.425 & $54,4 \%$ & 4.386 & 4.468 & 8.854 & $50,5 \%$ & $296,5 \%$ & $238,9 \%$ & $-3,9 \%$ \\
\hline PE & 1.075 & 640 & 1.715 & $37,3 \%$ & 3.815 & 1.982 & 5.797 & $34,2 \%$ & $255,0 \%$ & $209,7 \%$ & $-3,1 \%$ \\
\hline PB & 496 & 321 & 818 & $39,3 \%$ & 1.699 & 963 & 2.662 & $2 \%$ & $242,2 \%$ & $199,7 \%$ & $-3,1 \%$ \\
\hline MG & 1.974 & 2.550 & 4.525 & $56,4 \%$ & 6.454 & 7.357 & 13.810 & $53,3 \%$ & $226,9 \%$ & $188,5 \%$ & $-3,1 \%$ \\
\hline $\mathrm{RN}$ & 470 & 318 & 788 & $40,4 \%$ & 1.432 & 852 & 2.284 & $37,3 \%$ & $204,6 \%$ & $167,6 \%$ & $-3,1 \%$ \\
\hline $\mathrm{AL}$ & 542 & 207 & 749 & $27,7 \%$ & 1.801 & 625 & 2.426 & $25,8 \%$ & $232,5 \%$ & $201,3 \%$ & $-1,9 \%$ \\
\hline SE & 342 & 216 & 558 & $38,7 \%$ & 1.051 & 622 & 1.673 & $37,2 \%$ & $207,2 \%$ & $188,3 \%$ & $-1,5 \%$ \\
\hline $\mathrm{RO}$ & 224 & 258 & 482 & $53,6 \%$ & 667 & 730 & 1.396 & $2,3 \%$ & $197,9 \%$ & $182,7 \%$ & $-1,3 \%$ \\
\hline ES & 807 & 435 & 1.243 & $35,0 \%$ & 1.697 & 868 & 2.566 & $33,8 \%$ & $110,3 \%$ & $99,4 \%$ & $-1,2 \%$ \\
\hline MA & 1.292 & 367 & 1.658 & $22,1 \%$ & 4.943 & 1.309 & 6.252 & $20,9 \%$ & $282,7 \%$ & $256,9 \%$ & $-1,2 \%$ \\
\hline MT & 388 & 432 & 820 & $52,6 \%$ & 1.313 & 1.414 & 2.727 & $51,8 \%$ & $238,2 \%$ & $227,5 \%$ & $-0,8 \%$ \\
\hline $\mathrm{AM}$ & 496 & 402 & 898 & $44,7 \%$ & 1.990 & 1.609 & 3.599 & $44,7 \%$ & $300,8 \%$ & $300,5 \%$ & $0,0 \%$ \\
\hline DF & 0 & 711 & 711 & $100,0 \%$ & 0 & 1.957 & 1.957 & $100,0 \%$ & & $175,3 \%$ & $0,0 \%$ \\
\hline $\mathrm{AC}$ & 115 & 196 & 310 & $63,0 \%$ & 360 & 617 & 978 & $63,2 \%$ & $214,0 \%$ & $215,6 \%$ & $0,1 \%$ \\
\hline PA & 1.284 & 494 & 1.778 & $27,8 \%$ & 4.986 & 2.033 & 7.019 & $29,0 \%$ & $288,2 \%$ & $311,9 \%$ & $1,2 \%$ \\
\hline BA & 2.300 & 864 & 3.164 & $27,3 \%$ & 7.336 & 2.958 & 10.294 & $28,7 \%$ & $218,9 \%$ & $242,5 \%$ & $1,4 \%$ \\
\hline PI & 521 & 213 & 734 & $29,0 \%$ & 1.837 & 898 & 2.735 & $32,8 \%$ & $252,7 \%$ & $321,9 \%$ & $3,8 \%$ \\
\hline $\mathrm{CE}$ & 1.415 & 358 & 1.773 & $20,2 \%$ & 4.494 & 1.419 & 5.912 & $24,0 \%$ & $217,5 \%$ & $296,8 \%$ & $3,8 \%$ \\
\hline Brasil & 25.429 & 22.623 & 48.052 & $47,1 \%$ & 86.645 & 61.782 & 148.427 & $41,6 \%$ & $240,7 \%$ & $173,1 \%$ & $-5,5 \%$ \\
\hline
\end{tabular}

Fonte: FNDE

Sobre a extensão dos efeitos demográficos nas políticas educacionais Wong e Carvalho (2006) afirmam:

O tamanho das populações com menos de 15 anos, muito provavelmente, diminuirá até 2050, embora os vários subgrupos etários envolvidos experimentem taxas de crescimento oscilantes. Obviamente, como foi o caso dos países do sul e sudeste asiático, a diminuição oferecerá oportunidades demográficas claras para se chegar a uma educação, nos níveis fundamental e médio, universal e de qualidade. Para atingir este objetivo, um novo 
modelo educacional, com flexibilidade suficiente para permitir que sejam antecipadas as variações de demanda geradas pelas oscilações populacionais, torna-se essencial (WONG; CARVALHO, 2006, p. 16).

\subsubsection{A Questão pedagógica}

A transferência de recurso por aluno não é neutra em termos pedagógicas, o desenho do fundo privilegia um determinado pensamento pedagógico. Jacomini (2010) identifica duas formas de organização do ensino, a do "ensino e a aprendizagem" e a "reprodução e à exclusão". Paro (2011) é taxativo em relação aos modelos e trata:

[do] caráter antipedagógico da reprovação e que o sistema seriado não se sustenta a luz da teoria pedagógica e tem servido para jogar sobre o aluno a culpa pela incompetência do própria sistema de ensino em levá-lo a aprender (PARO, 2011, P. 697).

Ao analisar o Fundeb segundo estas duas formas de organização do ensino, uma que delega ao aluno a responsabilidade pelo resultado do sistema escolar, associada às políticas de reprovação, e a outra, que responsabiliza o Estado e os governantes pelo resultado do sistema escolar, denominada de progressão continuada, se verifica que a forma de organização de ensino gera um movimento de matrículas distinto entre as redes, enquanto nas redes que adotam as políticas de progressão continuada a taxa de distorsão idade série e de abandono são menores nas redes com políticas de reprovação as taxas são elevadas. O resultado destas políticas não tende ao equilíbrio, as taxas de abandono maiores referente as políticas de reprovação escolar não reduzem o contingente de matrículas, uma vez que um dos principais fatores de abandono escolar é a repetência.

$\mathrm{O}$ ingresso tardio e/ou a repetência são os fatores geradores e muitas são as decorrências pela condição de os alunos estarem em sala de aula acima da idade dos demais. A literatura tem apontado que a repetência gera consequências muito negativas não somente para $\mathrm{o}$ indivíduo, mas para o sistema educacional como um todo. Esse fato ocasiona um estímulo à evasão, prejudicando o andamento do estudante no fluxo do sistema educativo, também resultando em desperdício de recursos financeiros e frustrações de perspectivas pessoais. Além disso, cabe evidenciar que parte das políticas públicas voltadas para a melhoria da qualidade do ensino preocupa-se com o fracasso escolar e com o fato de a defasagem idade-série estar atuando diretamente no resultado dos indicadores de evasão, abandono e reprovação (FRITSCH; VITELLI; ROCHA, 2014, p. 221).

O elevado contingente de alunos em distorção em idade série infla o número de matrículas da rede ensino, que não é equilibrado nem mesmo com as taxas de abandono. Em 
2015 , o percentual de alunos do ensino médio acima da idade adequada superava os $30 \%$ em 5 estados, em 10 estados o número de alunos acima da idade adequada nas séries finais do ensino fundamental ultrapassava $20 \%$.

Tabela 7 - Participação das matrículas acima da idade adequada em relação ao total de cada etapa de ensino, Unidade Federativa, 2015

\begin{tabular}{|c|c|c|c|c|c|c|c|c|c|}
\hline \multirow[b]{2}{*}{ UF } & \multicolumn{3}{|c|}{$\begin{array}{l}\text { Ensino Fundamental Séries } \\
\text { Iniciais }\end{array}$} & \multicolumn{3}{|c|}{$\begin{array}{c}\text { Ensino Fundamental Séries } \\
\text { Finais }\end{array}$} & \multicolumn{3}{|c|}{ Ensino Médio } \\
\hline & Total & $\begin{array}{c}\text { Acima da } \\
\text { idade } \\
\text { adequada }\end{array}$ & $\begin{array}{c}\% \text { de } \\
\text { matrículas } \\
\text { acima da } \\
\text { idade } \\
\text { adequada }\end{array}$ & Total & $\begin{array}{c}\text { Acima da } \\
\text { idade } \\
\text { adequada }\end{array}$ & $\begin{array}{c}\% \text { de } \\
\text { matrículas } \\
\text { acima da } \\
\text { idade } \\
\text { adequada }\end{array}$ & Total & $\begin{array}{c}\text { Acima da } \\
\text { idade } \\
\text { adequada }\end{array}$ & $\begin{array}{c}\% \text { de } \\
\text { matrículas } \\
\text { acima da } \\
\text { idade } \\
\text { adequada }\end{array}$ \\
\hline $\begin{array}{l}\text { Estados que receberam a } \\
\text { comple mentação da União }\end{array}$ & 5.697 & 858 & $15,1 \%$ & 4.410 & 937 & $21,3 \%$ & 2.634 & 737 & $28,0 \%$ \\
\hline Pará & 876 & 165 & $18,8 \%$ & 599 & 144 & $24,1 \%$ & 360 & 137 & $38,1 \%$ \\
\hline Amazonas & 418 & 65 & $15,5 \%$ & 305 & 67 & $21,8 \%$ & 190 & 63 & $33,3 \%$ \\
\hline Piauí & 287 & 47 & $16,3 \%$ & 219 & 47 & $21,6 \%$ & 143 & 44 & $30,6 \%$ \\
\hline Bahia & 1.170 & 206 & $17,6 \%$ & 954 & 236 & $24,8 \%$ & 553 & 168 & $30,3 \%$ \\
\hline Sergipe & 194 & 34 & $17,6 \%$ & 150 & 39 & $25,7 \%$ & 82 & 24 & $29,7 \%$ \\
\hline Alagoas & 293 & 48 & $16,3 \%$ & 230 & 54 & $23,4 \%$ & 123 & 34 & $27,2 \%$ \\
\hline Maranhão & 697 & 86 & $12,3 \%$ & 539 & 112 & $20,7 \%$ & 312 & 83 & $26,4 \%$ \\
\hline Pernambuco & 743 & 103 & $13,8 \%$ & 581 & 102 & $17,5 \%$ & 365 & 81 & $22,1 \%$ \\
\hline Paraíba & 323 & 47 & $14,6 \%$ & 255 & 53 & $20,9 \%$ & 133 & 29 & $21,8 \%$ \\
\hline Ceará & 695 & 58 & $8,4 \%$ & 578 & 84 & $14,5 \%$ & 373 & 75 & $20,2 \%$ \\
\hline Demais estados & 9.766 & 730 & $7,5 \%$ & 7.959 & 1.005 & $12,6 \%$ & 5.442 & 749 & $13,8 \%$ \\
\hline Rio Grande do Norte & 274 & 41 & $14,8 \%$ & 213 & 47 & $22,2 \%$ & 129 & 43 & $32,9 \%$ \\
\hline Amapá & 80 & 12 & $14,9 \%$ & 56 & 10 & $17,6 \%$ & 40 & 10 & $24,4 \%$ \\
\hline Acre & 99 & 16 & $16,0 \%$ & 64 & 12 & $18,4 \%$ & 44 & 10 & $22,9 \%$ \\
\hline Mato Grosso do Sul & 226 & 27 & $12,0 \%$ & 174 & 35 & $20,2 \%$ & 93 & 20 & $20,9 \%$ \\
\hline Tocantins & 141 & 14 & $9,7 \%$ & 110 & 19 & $17,5 \%$ & 69 & 14 & $20,4 \%$ \\
\hline Rio de Janeiro & 1.128 & 145 & $12,8 \%$ & 936 & 172 & $18,4 \%$ & 583 & 113 & $19,3 \%$ \\
\hline Mato Grosso & 262 & 12 & $4,5 \%$ & 200 & 14 & $6,9 \%$ & 158 & 28 & $18,0 \%$ \\
\hline Goiás & 489 & 42 & $8,6 \%$ & 398 & 54 & $13,7 \%$ & 256 & 44 & $17,4 \%$ \\
\hline Rondônia & 164 & 20 & $12,3 \%$ & 113 & 21 & $18,6 \%$ & 65 & 11 & $16,8 \%$ \\
\hline Rio Grande do Sul & 741 & 85 & $11,5 \%$ & 590 & 98 & $16,6 \%$ & 385 & 60 & $15,5 \%$ \\
\hline Minas Gerais & 1.382 & 59 & $4,2 \%$ & 1.276 & 163 & $12,8 \%$ & 787 & 120 & $15,3 \%$ \\
\hline Paraná & 794 & 42 & $5,2 \%$ & 652 & 75 & $11,5 \%$ & 474 & 72 & $15,2 \%$ \\
\hline Roraima & 53 & 6 & $10,8 \%$ & 39 & 6 & $16,5 \%$ & 23 & 3 & $14,3 \%$ \\
\hline Espírito Santo & 289 & 33 & $11,3 \%$ & 220 & 33 & $15,1 \%$ & 132 & 18 & $14,0 \%$ \\
\hline Distrito Federal & 208 & 15 & $7,1 \%$ & 182 & 24 & $13,3 \%$ & 110 & 13 & $12,1 \%$ \\
\hline Santa Catarina & 463 & 35 & $7,5 \%$ & 374 & 45 & $11,9 \%$ & 242 & 26 & $10,5 \%$ \\
\hline São Paulo & 2.973 & 130 & $4,4 \%$ & 2.361 & 175 & $7,4 \%$ & 1.851 & 144 & $7,8 \%$ \\
\hline
\end{tabular}

Fonte: Sinopse da Educação Básica 2015

A repetência amplia o número de anos na unidade escolar, mesmo que o aluno interrompa os estudos antes da conclusão do ensino médio. Como o Fundeb contabiliza todas as matrículas, seja na idade adequada ou não, o peso relativo do ente que institui uma política de reprovações é maior do que aquele que estabelece uma política de progressão continuada. Este efeito pode gerar privilégios tanto no âmbito intraestadual, entre o estado e os 
municípios, como no âmbito interestadual, na divisão de recursos da complementação da União. Um caso ilustrativo deste desequilíbrio se verifica na disputa da complementação da União pelo estado de Minas Gerais, o valor per capita no estado é apenas 2,6\% superior ao dos estados que recebem complementação da União, contudo, o governo do estado de Minas Gerais adota o sistema de progressão continuada e registra um dos menores percentuais de disfunção idade série no ensino médio $(15,3 \%)$, se estivesse no modelo de reprovação, registrando taxas de disfunções idade série semelhantes aos dos estados que recebem a complementação da União $(28,0 \%)$ o contingente de matrículas aumentaria e o valor per capita do estado seria inferior ao valor mínimo nacional, passando a receber recursos da União.

Tabela 8 - Valor anual por aluno do Fundeb nas séries iniciais do ensino fundamental na zona urbana, 2015

\begin{tabular}{|c|c|c|}
\hline UF & $\begin{array}{c}\text { Ensino Fundamental } \\
\text { Séries Iniciais - Urbana }\end{array}$ & Situação \\
\hline Alagoas & $2.739,77$ & \multirow{9}{*}{$\begin{array}{c}\text { Estados que } \\
\text { recebem } \\
\text { complementação } \\
\text { da União }\end{array}$} \\
\hline Amazonas & $2.739,77$ & \\
\hline Bahia & $2.739,77$ & \\
\hline Ceará & $2.739,77$ & \\
\hline Pará & $2.739,77$ & \\
\hline Paraíba & $2.739,77$ & \\
\hline Pernambuco & $2.739,77$ & \\
\hline Piauí & $2.739,77$ & \\
\hline Rio Grande do Norte & $2.783,98$ & \\
\hline Minas Ge rais & $2.811,62$ & \\
\hline Mato Grosso & $2.816,69$ & \\
\hline Tocantins & $3.061,40$ & \\
\hline Sergipe & $3.119,47$ & \\
\hline Paraná & $3.171,98$ & \\
\hline Rio de Janeiro & $3.203,18$ & \\
\hline Goiás & $3.242,04$ & \\
\hline Rondônia & $3.289,37$ & Estados que não \\
\hline Santa Catarina & $3.304,97$ & recebem \\
\hline Acre & $3.317,39$ & complementação \\
\hline Mato Grosso do Sul & $3.322,34$ & da União \\
\hline Espírito Santo & $3.362,39$ & \\
\hline Distrito Federal & $3.460,99$ & \\
\hline São Paulo & $3.561,55$ & \\
\hline Rio Grande do Sul & $3.578,28$ & \\
\hline Maranhão & $3.739,77$ & \\
\hline Amapá & $3.803,96$ & \\
\hline Roraima & $4.744,08$ & \\
\hline
\end{tabular}

Fonte: Portaria Interministerial $n^{\circ} 07$ de 16 de dezembro de 2016. 
O atual formato do Fundeb, de distribuição de recursos por aluno, gera resultados diferentes conforme a organização do ensino, com peso maior na obtenção de recursos aos entes que desenvolvem políticas de estímulo à repetência. Não se trata de excluir as matrículas de alunos com idade acima da adequada, pois esta medida geraria um impacto invertido, se trata de superar a repartição de recursos segundo matrículas.

\subsubsection{A Questão financeira}

Há dois pontos a serem observados em relação a definição da matrícula como eixo de distribuição de recursos: a indução na redução do número de equipamentos educacionais e a sustentação da percepção de que o aluno é o centro dos custos.

O fechamento das escolas é ainda mais contraditório quando observado que o Plano Nacional de Educação (PNE) instituiu como meta que a educação em tempo integral seja ofertada em, no mínimo, $50 \%$ das escolas públicas, de forma a atender, pelo menos, $25 \%$ dos alunos da educação básica. Segundo o Observatório do PNE em 2017 apenas 28,9\% das escolas de ensino fundamental possuíam matrículas em tempo integral. Ao invés de aproveitar espaços ociosos para ampliação do tempo do aluno na escola a gestão educacional é induzida ao fechamento de equipamentos para equilibrar as contas da pasta educacional.

Esta relação coloca em evidência que enquanto a receita está vinculada ao aluno, a maior parte dos custos com manutenção e desenvolvimento do ensino estão atrelados à escola ou às turmas. Os custos em que o aluno é peça central são oriundos dos programas de acesso e permanência, como transporte escolar, distribuição de material didático e alimentação escolar, contudo os custos mais representativos estão atrelados as turmas, como as despesas com os profissionais do magistério, ou a escola, com as despesas de infraestrutura escolar. Deste modo, ao eleger a matrícula como guia para distribuição de recursos existe um descolamento entre as receitas e as despesas para efetivar o direito à educação.

O aluno na equação do financiamento do ensino é a matriz de distribuição de receitas, e por equilíbrio, seria o centro de custos das redes de ensino. Contudo, em uma rede de ensino constituída, em que já está estabelecida a razão de número de alunos por turma, a variação do número de alunos é no máximo uma variação do custo marginal, referente a uma pequena parcela dos insumos, mas o coeficiente de receitas do Fundeb não capta estas variações. 
Neste sentido a estrutura de financiamento do Fundeb incentiva o aumento do número de alunos por turma, o fechamento de turmas e de unidades escolares, ou seja, a ampliação de receitas sem aumento de custos ou redução de despesas para equilíbrio financeiro.

A queda nas matrículas de ensino fundamental introduziu a dinâmica de diminuição de turmas e o fechamento de estabelecimentos educacionais, o número de turmas no ensino fundamental registrou queda de 60,7 mil e o encerramento das atividades em 22,7 mil estabelecimentos educacionais, impacto negativo de 14,7\%. Em todas as etapas de ensino houve redução do número de alunos por turma, com redução média de 11,3\%. Como a matrícula é a fonte de recursos para os entes, com a sua redução a receita para aplicação na rede de ensino se reduz, seja nominal ou percentualmente, isto implica em uma tomada de decisão do gestor, pois enquanto a receita se reduz, os custos para manutenção permanecem ou aumentam. Em determinados casos a administração consegue desmobilizar parte da equipe e fechar equipamentos educacionais, enquanto em outros possui restrições para reduzir os custos, especificamente dos servidores.

Tabela 9 - Matrículas, estabelecimentos educacionais, turmas e número de alunos por turma na educação básica. Brasil, $2007-2017$

\begin{tabular}{l|r|r|r|r}
\hline \multirow{2}{*}{ Etapa de Ensino } & \multicolumn{2}{|c|}{ Período } & \multicolumn{2}{c}{ Variação 2017/2007 } \\
\cline { 2 - 5 } & \multicolumn{1}{c|}{$\mathbf{2 0 0 7}$} & \multicolumn{1}{c|}{$\mathbf{2 0 1 7}$} & \multicolumn{1}{c}{ Nominal } & \multicolumn{1}{c}{$\%$} \\
\hline Matrículas & 53.028 .928 & 48.608 .093 & -4.420 .835 & $-8,3 \%$ \\
Educação Infantil & 6.509 .868 & 8.508 .731 & 1.998 .863 & $30,7 \%$ \\
Ensino Fundamental & 32.122 .273 & 27.348 .080 & -4.774 .193 & $-14,9 \%$ \\
Ensino Médio & 8.369 .369 & 7.930 .384 & -438.985 & $-5,2 \%$ \\
\hline Estabelecimentos Educacionais & 198397 & 184145 & -14252 & $-7,2 \%$ \\
Educação Infantil & 110.782 & 116.472 & 5.690 & $5,1 \%$ \\
Ensino Fundamental & 154.321 & 131.606 & -22.715 & $-14,7 \%$ \\
Ensino Médio & 24.266 & 28.558 & 4.292 & $17,7 \%$ \\
\hline Número de Turmas & 2.098 .756 & 2.169 .220 & 70.464 & $3,4 \%$ \\
Educação Infantil & 353.457 & 516.888 & 163.431 & $46,2 \%$ \\
Ensino Fundamental & 1.265 .433 & 1.204 .695 & -60.738 & $-4,8 \%$ \\
Ensino Médio & 243.420 & 260.698 & 17.278 & $7,1 \%$ \\
\hline Número de Alunos por Turma & 25,3 & 22,4 & $-2,9$ & $-11,3 \%$ \\
Educação Infantil & 18,4 & 16,5 & $-2,0$ & $-10,6 \%$ \\
Ensino Fundamental & 25,4 & 22,7 & $-2,7$ & $-10,6 \%$ \\
Ensino Médio & 34,4 & 30,4 & $-4,0$ & $-11,5 \%$ \\
\hline
\end{tabular}

Fonte:Sinopse Estatística da Educação Basica/FNDE

A redução do número de matrículas pode ocorrer de forma intensa em uma região, ou dispersa em todo território, enquanto no primeiro caso a administração pode buscar formas de minorar os seus efeitos no sistema, com a redução do número turmas, permitindo que os 
profissionais do magistério sejam alocados em outras atividades, no segundo exemplo, há apenas a redução no número de alunos por turma, o que pode implicar na precarização das condições de trabalho dos profissionais do magistério e da retração dos recursos destinados para manutenção das edificações escolares, assim, o efeito da redução do número de alunos por turma, desejado pedagogicamente, se transforma em um problema para gestão pública.

Desta forma, o repasse de recursos do Fundeb segundo número de matrículas segue uma tendência pró-cíclica, enquanto há crescimento de matrículas ocorre acréscimo de recursos, mas em um cenário de queda, seja ela por ação da administração pública ou por fatores externos, há retração da receita.

O corte de despesas básicas e o fechamento de escolas são induzidos pelo atual sistema de financiamento da educação, a matriz de repasse centrada no aluno, que não é um elemento de custo do sistema educacional, age contra qualquer métrica de equilíbrio das contas públicas.

\subsubsection{Distorção no cálculo de ensino em tempo integral}

Outro ponto relevante se refere a forma de contabilização do peso relativo a jornada escolar na transferência de recursos do fundo. O Ministério da Educação emite anualmente uma nota técnica da metodologia para definição dos critérios de filtragem do quantitativo de matrículas do Censo Escolar do ano anterior, para fins de operacionalização do Fundeb.

A Nota Técnica Conjunta $n^{\circ}$ 01/2017 (Brasil, 2017) define que para fins de apuração das matrículas é necessário desdobra-las em 19 segmentos: etapas de ensino (educação infantil, ensino fundamental e médio) modalidades (ensino regular, especial, jovens e adultos e profissional, técnico e tecnológico), localização (urbana e no campo), esfera administrativa (pública e conveniada/privada) e esfera de governo (estadual e municipal), os segmentos são assegurados pelo art. 10 da Lei $\mathrm{n}^{\mathbf{0}}$ 11.494/2017, sendo aplicado a cada segmento as ponderações, que variam de 0,70 a 1,30. As ponderações também diferem a duração da jornada escolar, parcial ou de tempo integral.

Para considerar uma matrícula em tempo integral a jornada escolar deve ter duração igual ou superior a sete horas diárias, durante todo o período letivo, compreendendo o tempo total que um mesmo aluno permanece na escola ou em atividades escolares. Para esta sistematização entra no computo a matrícula de escolarização e de atividade complementar, no caso da existência de mais de um vínculo de escolarização, será fator de soma a escolarização de maior duração. 
Após a categorização da jornada escolar é calculado o repasse segundo as ponderações. O ensino em tempo integral produz um acréscimo de até 30\% por etapa de ensino, localização e esfera administrativa. Neste sentido a educação em tempo integral na educação infantil e nos anos iniciais do ensino fundamental urbano apresenta um acréscimo de $30 \%$ em relação aquelas de tempo parcial, enquanto no ensino médio urbano o aumento é de apenas 5 pontos percentuais, e no ensino médio rural não há qualquer diferença (Tabela $10)$.

Tabela 10 - Diferença entre os fatores de ponderação por duração da jornada escolar segundo etapa de ensino, Fundeb 2018

\begin{tabular}{l|rr|r}
\hline \multirow{2}{*}{ Etapa de ensino } & \multicolumn{2}{|c|}{ Ponderações } & \multirow{2}{*}{ Acréscimo } \\
\cline { 2 - 3 } & Parcial & Integral & \\
\hline Creche pública & 1,00 & 1,30 & 0,30 \\
Creche conveniada & 0,80 & 1,10 & 0,30 \\
Pré-escola & 1,00 & 1,30 & 0,30 \\
Ensino Fundamental Anos Iniciais - Urbano & 1,00 & 1,30 & 0,30 \\
Ensino Fundamental Anos Iniciais - Rural & 1,15 & 1,30 & 0,15 \\
Ensino Fundamental Anos Finais - Urbano & 1,10 & 1,30 & 0,20 \\
Ensino Fundamental Anos Finais - Rural & 1,20 & 1,30 & 0,10 \\
Ensino Médio Urbano & 1,25 & 1,30 & 0,05 \\
Ensino Médio Rural & 1,30 & 1,30 & - \\
\hline
\end{tabular}

Fonte: Nota Técnica Conjunta n ${ }^{\circ} 01 / 2017$

Isto posto, é notória a defasagem entre ensino parcial e integral, o aumento da jornada escolar implica na elevação de recursos tanto para infraestrutura escolar como para remuneração dos profissionais do magistério. A fixação de dois tempos para jornada prejudica os movimentos de deslocamento em favor da expansão da carga horária, não haveria regra de ponderação melhor do que a própria jornada do aluno.

As despesas com uma turma de 30 horas semanais são notoriamente superiores à de uma de 15 horas semanais, mas pelo Fundeb o repasse é equivalente. Não há motivo para uma classificação binária em tempo parcial e integral, a variação da jornada escolar é o indicador mais qualificado para mensuração do tempo de permanência do aluno na unidade escolar. 


\section{O EMBATE SOBRE QUALIDADE DA EDUCAÇÃO: AS ORIGENS DO CUSTO ALUNO-QUALIDADE}

O Manifesto dos Pioneiros da Educação Nova aponta para dificuldade de definir uma educação de qualidade, pois "diferentes camadas e grupos (classes) de uma sociedade dada terão respectivamente opiniões diferentes sobre a 'concepção do mundo, que convém fazer adotar ao educando e sobre o que é necessário considerar como "qualidade socialmente útil"”. Para Anísio Teixeira (2015), o mínimo de educação oferecido por um sistema de escolas públicas e gratuitas estaria "condicionado pelo desenvolvimento brasileiro e pelos recursos disponíveis da nação para a educação".

Teixeira (2015) além de correlacionar a qualidade da educação com o desenvolvimento do país, sustenta que a produção intelectual deve interpretar a realidade brasileira para propor formas de melhoria da distribuição dos recursos disponíveis para construção de um sistema nacional de educação. Para o autor a receita tributária vinculada à educação seria dividida em quotas por aluno e o sistema escolar - municipal - financiado por tais recursos, os estados e a União complementaria o investimento transferindo recursos por aluno (TEIXEIRA, 2015). O artigo de Anísio Teixeira originalmente publicado na Revista Brasileira de Estudos Pedagógicos em dezembro de 1953 se aproxima da estratégia desenvolvida pelo Ministro da Educação, Paulo Renato Souza, para criação do Fundo de Manutenção e Desenvolvimento do Ensino Fundamental e de Valorização do Magistério (Fundef) em 1996.

Os estudos mais consistentes sobre o custo de uma educação de qualidade surgem, ainda, nos anos 80, a mensuração dos custos por aluno nos estudos de PARO (1981) nas escolas estaduais de São Paulo, em COSTA (1991) com os CIEPS $^{10}$ no Rio de Janeiro, e a análise dos padrões mínimos de qualidade com XAVIER, AMARAL SOBRINHO e PLANK (1992). A agenda da qualidade da educação entra definitivamente na pauta educacional nos anos 2000 .

A definição objetiva de qualidade não é métrica neutra, assim, este capítulo examina a noção sobre qualidade da educação na arena educacional brasileira sobre a qual se tem o registro da ascensão de dois grupos de atores que alcançaram espaço de destaque sobre a questão e disputam a hegemonia sobre interpretação em relação ao tema (GUSMÃO, 2013a). A qualidade da educação está longe de ser uma unanimidade e se há consenso entre os pesquisadores é de que o conceito de qualidade da educação está em disputa.

\footnotetext{
${ }^{10}$ Centros Integrados de Educação Pública.
} 
Gusmão (2013b) identifica cinco abordagens sobre o tema, a primeira composta por pesquisadores $^{11}$ que atribuem o significado de qualidade ao processo de expansão da escolarização, ressaltando a importância política da universalização do acesso. A segunda compreende que os resultados em avaliação de larga escala possibilitam a melhor interpretação em referência ao assunto. A seguinte entende qualidade sob uma visão economicista, em que "é colocada como um conceito de sentido mercantil e antidemocrático, que mais atende à manutenção da desigualdade educacional do que à promoção da igualdade e à garantia do direito à educação". A quarta estabelece que a qualidade seja analisada por meio de ações "relativas à diversidade, como o direito às identidades, à pluralidade cultural e às diferenças”. Por fim, a quinta defende que as mudanças necessárias não passam pela reforma do atual modelo de educação, mas pela substituição das suas bases, o que denotaria "alterar a concepção de educação fundamentada na transmissão de conhecimento para uma baseada na produção de conhecimento".

Enquanto Gusmão (2013b) analisa a disputa de visões e posicionamentos ideológicos distintos, Dourado, Oliveira e Santos (2007) pretendem abarcar quase que a totalidade de dimensões e níveis a serem analisados quando o assunto é qualidade da educação. Em outro artigo Gusmão (2013a), apresenta o resultado de uma pesquisa qualitativa com os principais atores sociais $^{12}$ situados no Estado e na sociedade civil na arena educacional brasileira, os depoimentos demarcaram dois grupos:

a oposição se deu entre os atores que concebem a "aprendizagem" (entendida primordialmente por meio dos resultados das provas em larga escala) como o principal significado de qualidade da educação e os que defendem uma visão abrangente, com o foco estendido aos processos, às condições gerais de ensino e o aprendizado em uma perspectiva mais ampla que o aferido pelas provas (GUSMÃO, 2013a, p. 106).

Segundo Gusmão (2013a) a demarcação dos grupos também pode ser apresentada como os que se orientam pelo rendimento dos estudantes, e outro, pelos insumos e processos. A partir da identificação destes grupos que disputam a hegemonia da interpretação sobre qualidade da educação pretende-se analisar a trajetória de ambos no período recente.

\footnotetext{
${ }^{11}$ Para Gusmão (2013b) são integrantes deste grupo Adams (2000), Campos (2000), Azanha (2004), Carvalho (2004), Beisiegel (2006) e Oliveira (2005).

${ }^{12}$ Segundo Gusmão (2013a) foram entrevistadas 13 pessoas, as quais representavam as seguintes instituições: Comissão de Educação e Cultura da Câmara dos Deputados, Conselho Nacional de Educação, Ministério da Educação, Banco Mundial, Unicef, União Nacional dos Dirigentes Municipais de Educação, Confederação Nacional dos Trabalhadores em Educação, Associação Nacional de Pós-Graduação e Pesquisa em Educação, Campanha Nacional pelo Direito à Educação, Instituto Ayrton Senna, Todos pela Educação.
} 


\subsection{Foco na aprendizagem}

Para Torres (2001), a Conferência Mundial sobre Educação para Todos, realizada em Jomtien (Tailândia) em 1990, é o marco da centralidade da aprendizagem no ideário educacional, o artigo quarto da declaração da conferência orienta que:

a educação básica deve estar centrada na aquisição e nos resultados efetivos da aprendizagem, e não mais exclusivamente na matrícula, freqüência aos programas estabelecidos e preenchimento dos requisitos para a obtenção do diploma (UNESCO, 1990)

A proposta do documento ainda equaciona a necessidade de abordagens participativas para assegurar a aprendizagem, destacando que por meio destas seria necessário identificar "os níveis desejáveis de aquisição de conhecimentos" e "implementar sistemas de avaliação de desempenho". Para a autora,

a concentração na aprendizagem implica partir e dar prioridade ao ponto de vista da demanda e do aluno, romper com uma tradição educativa que definiu historicamente seu trabalho a partir da oferta e do ponto de vista do ensino e, portanto, dar uma profunda virada no paradigma educativo e escolar convencional. (TORRES, 2001, p 44).

Torres (2001) sustenta que tal interpretação foi implementada de forma "empobrecida" pelos sistemas de ensino, pois a aprendizagem foi sintetizada como melhoria do rendimento escolar, por meio da generalização da aplicação de provas em larga escala. Tal forma de avaliação iria de encontro à nova concepção de gestão, patrocinada pelas reformas do Estado, que no Brasil foi materializada pelo Plano Diretor da Reforma do Aparelho do Estado, estabelecido pelo então Ministério da Administração Federal e Reforma do Estado (Mare), que adotou parte das diretrizes da Nova Gestão Pública (NGP). A NGP teria como objetivo o enfrentamento de dois problemas burocráticos: o excesso de procedimentos e a baixa responsabilização dos burocratas. Como resposta sua instrução principal era no intuito de flexibilizar a administração pública e aumentar a accountability (Abrucio, 2006). Para concretização dos objetivos da NGP era essencial,

A adoção de uma administração pública voltada para resultados, baseada em mecanismos de contratualidade da gestão, com metas, indicadores e formas de cobrar os gestores, e apoiada na transparência das ações governamentais, possibilitando o controle maior dos cidadãos e o uso de outros instrumentos de accountability (SANO; ABRUCIO, 2008, p. 66).

A implementação de tal modelo pressupõe que a gestão seja orientada por resultados ao invés de se pautar por insumos e procedimentos, tais preceitos implicam de um lado na desregulamentação de carreiras do setor público, com a contratação de trabalhadores segundo a Consolidação das Leis Trabalhista (CLT), para evitar os estatutos dos profissionais do 
magistério, na liberação de compras de bens e serviços sem a necessidade de processo licitatório e na criação de controles para acompanhamento dos resultados por meio de metas e indicadores, responsabilizando gestores e trabalhadores pelo produto e serviço entregue. Para reafirmar a importância de tais modificações Sano e Abrucio (2008) afirmam que na,

visão do ministro Bresser-Pereira, o sistema administrativo brasileiro, nascido da Constituição de 1988, tinha realçado os piores elementos do modelo burocrático, com o reforço da lógica dos procedimentos, a uniformização e o "engessamento" da estrutura dos órgãos públicos e da política de pessoal, somados ao baixo controle público da burocracia (SANO; ABRUCIO, 2008, p. 66).

No âmbito da educação básica a principal iniciativa do governo federal no sentido de gestão por resultados foi a criação do Sistema Nacional de Educação Básica (Saeb), que começou como uma avaliação de proficiência dos alunos, em português e matemática, por amostragem das redes de ensino, que serviria como diagnóstico das gestões dos sistemas educacionais. A partir de 2005 o Saeb ganha novos contornos, sendo incorporada a Avaliação Nacional do Rendimento Escolar (Anresc), mais conhecida como Prova Brasil, de base censitária, com resultados por escolas (Sousa, 2014).

As informações de rendimentos dos estudantes na Prova Brasil e os dados de fluxo escolar deram origem ao Índice de Desenvolvimento da Educação Básica (Ideb), criado pelo Plano de Desenvolvimento da Educação (PDE) em 2007. CAMARGO, PINTO e GUIMARÃES (2008) questionaram a utilização do índice como forma de instigar a qualidade da educação e como critério para repasse dos programas suplementares aos demais entes. Além disso, alertaram que a lógica do Ideb levaria a uma comparação entre melhores e piores, municípios e escolas, sem qualquer dado de contexto para compreender a desigualdade socioeconômica.

A disseminação e os usos dos resultados da avaliação influenciam diretamente o debate educacional, Sousa (2014) sistematiza cinco traços dominantes destes testes que impactam no significado de qualidade da educação: i) redução da noção de qualidade ao resultado das provas padronizadas, desconsiderando "os contextos de produção e reprodução dos saberes escolares"; ii) "estreitamento da noção de currículo" e consequente "homogeneização do que se ensina em todo o Brasil"; iii) reforço da cultura tradicional de avaliação por meio de provas, enfraquecimento das avaliações participativas e retorno na noção de repetência como sinônimo de qualidade; iv) responsabilização dos trabalhadores 
pelo resultado dos alunos nos testes, alinhada a uma política de bonificação por resultados; v) a proliferação das avaliação em larga escala no âmbito estadual e municipal.

Sousa (2014) ainda destaca que,

Os desempenhos dos alunos nas avaliações de larga escala, como expressão de qualidade, pouco a pouco vêm subsidiando diversas iniciativas de gestão das redes, que se apresentam em nome da promoção dessa qualidade. Sob o argumento da transparência, vêm se inserindo nos programas e planos governamentais, mecanismos que visam dar ampla visibilidade aos resultados das avaliações e, em alguns casos, responsabilização de profissionais ou da escola por esses resultados, traduzida na implantação de incentivos simbólicos ou monetários, com vistas à indução de mudanças. A alocação de recursos diferenciados para as escolas, como meio de premiação por bons resultados, revela a crença de que se a competição no interior das redes de ensino induz a melhores resultados. O mesmo pressuposto está presente em iniciativas de incentivos monetários aos profissionais das escolas (SOUSA, 2014, p. 412).

Ao privilegiar o resultado, compreendido como a variação de índices educacionais compostos majoritariamente pelo desempenho de estudantes em exames de larga escala, esta corrente obteve enorme crescimento nos últimos anos. Inúmeros governos adotaram tais práticas e há predominância desta visão entre as organizações do terceiro setor na área educacional. A ideia de apresentar resultados em intervalos curtos fortalece esse grupo ao propagandear a mensagem de que controle, transparência e de compromisso com melhorias imediatas.

A ausência de registros detalhados sobre as ações escolares, a inabilidade dos governos em estabelecer planos de carreira sustáveis no curto e longo prazo e uma gestão de contratos que atua primordialmente para suprir as necessidades imediatas das unidades escolares contribui para o fortalecimento e ascensão de métricas preocupadas quase que exclusivamente pela melhoria dos indicadores, que em muitas ocasiões, não tem qualquer reflexo com a realidade educacional.

Em síntese o resultado da política educacional é o eixo central desta corrente, o planejamento de médio e longo prazo perde importância, e todas as ações do poder público, ou de entidades conveniadas, são contratualizadas com devolutivas em curtos períodos de tempo.

\section{2 Ênfase em insumos, processos e às condições gerais de ensino}

O debate sobre a qualidade da educação sob a perspectiva que considera as condições materiais das escolas e dos sistemas de ensino se apresenta como um esforço de construção 
coletiva de "uma história construída por muitos movimentos, organizações, coletivos, gente de diferentes épocas e lugares" (Carreira e Pinto, 2007). Determinados processos são associados a este grupo: como a mobilização no processo constituinte para assegurar a garantia do direito à educação, à influência no Estatuto da Criança e Adolescente ao estabelecer padrões qualitativos de atendimento, bem como do direito a escola próxima à residência, a aprovação na Comissão de Educação, Cultura e Desporto da Câmara dos Deputados do substitutivo do deputado Jorge Hage ao Projeto de Lei de Diretrizes e Bases da Educação Nacional em junho de 1990, que "incorporava várias medidas de forte impacto na qualidade do ensino público" (Carreira e Pinto, 2007).

Contudo, a Conferência de Educação para Todos em Jomtien também se apresenta como um marco para este grupo, a crítica da relativização do dever do Estado com a educação mobilizou diversas entidades ligadas à educação. A organização das entidades influenciou na realização da Semana Nacional de Educação para Todos em maio de 1993 no Brasil, com a assinatura do Compromisso Nacional da Educação para Todos, que tinha como objetivo orientar a elaboração do plano decenal de educação. Os compromissos asseguravam a progressiva participação percentual do gasto público em educação em relação ao Produto Interno Bruto (PIB) brasileiro, de forma a atingir o índice de 5,5\%, aumentar progressivamente a remuneração do magistério público, com planos de carreira e aumentos reais de salário, dentre outros temas (Carreira e Pinto, 2007). Contudo, o acordo foi desconsiderado pelo governo seguinte, do presidente Fernando Henrique Cardoso, que ignorou, categoricamente, a participação da sociedade nos dois mandatos presidenciais.

A sociedade civil neste ínterim promoveu o I e II Congresso Nacional de Educação, que resultou no documento Plano Nacional de Educação: proposta da sociedade brasileira. $\mathrm{O}$ plano foi apresentado pelo deputado Ivan Valente, mas o governo apresentou substitutivo que enfraqueceu a maioria das disposições, o último sopro ocorreu com as alterações promovidas pelo relator, porém os acréscimos substantivos foram vetados pelo Executivo (CARREIRA; PINTO, 2007)

No início dos anos 2000, a partir da referência da política de fundos, de distribuição de recursos conforme o número de matrículas surge em universidades públicas (UFG, 2003 e USP, UFG, UFPA, UFPR, UFRS, 2004) e no INEP (BRASIL, 2003, 2004 e 2006) inúmeros levantamentos para verificar o custo aluno em escolas da educação básica segundo condições para oferta de um ensino de qualidade, pesquisando uma nova métrica para distribuição dos recursos educacionais necessários para uma educação de qualidade. Neste período os trabalhos de SILVA (2000), FARENZENA (2004), CAMARGO (2006), PINTO (2005 e 
2006) e VERHINE (2006) aprofundam a discussão sobre o custo aluno-qualidade, e na obra "Custo Aluno-Qualidade Inicial: rumo à educação pública de qualidade no Brasil" são sistematizados por Denise Carreira e José Marcelino Rezende Pinto os resultados de pesquisa sobre o tema. A partir dessa contribuição a definição de qualidade sai da esfera teórica pra uma delimitação prática em que possa ser utilizada como mecanismo para distribuição de recursos vinculados ao ensino.

Os dois autores assinam o documento produzido pela Campanha Nacional pelo Direito à Educação, organização fundada em 1999, por uma articulação de entidades da sociedade civil que se reuniram no processo preparatório para a Cúpula Mundial de Educação, realizada em Dakar, no Senegal, em 2000. Logo, o Custo Aluno-Qualidade foi construído como resposta a um dos objetivos da Campanha Nacional pelo Direito à Educação: "contribuir para o aumento do financiamento educacional visando à implementação de um conjunto articulado, duradouro e coerente de políticas que garantam uma educação pública de qualidade".

$\mathrm{Na}$ opinião dos autores, ao referenciar a qualidade era necessário compreender a educação como um processo, que não poderia ser limitado à dimensão de resultados em testes estandardizados de desempenho nas disciplinas de Língua Portuguesa e Matemática (PINTO, 2015).

Carreira e Pinto (2007) entendem "a qualidade em educação como um conceito historicamente construído e em disputa, cabendo aos sujeitos políticos que atuam pelo direito à educação especificar quais significados e concepções manejam.“ Segundo, os autores a qualidade deveria se referenciar a um patamar mínimo, "digno de respeito, de direitos, para uma educação humanista, tolerante, não racista, não-sexista e estendida a todos."

Ao compreender a educação de qualidade como um processo, Carreira e Pinto sustentam que a educação deve promover sujeitos de vida plena, sujeitos de direitos por meio da inclusão cultural e social, com respeito à diversidade, à democracia e ao Estado de Direito. Para tanto o aumento de investimentos ocorreria no curto e no longo prazo, dando sustentabilidade às políticas de enfrentamento das desigualdades sociais em educação, reconhecendo os desafios ao desenvolvimento da região ou localidade. Isto sem desconsiderar as políticas que garantem o acesso ao direito à educação e ponderando que o mecanismo deve ser aprimorado por meio de "participação social e política, garantida por meio de uma institucionalidade e de processos participativos e democráticos que independem da vontade política do gestor ou gestora em exercício.” 
O avanço no debate sobre a implementação de um mecanismo de distribuição de recursos educacionais segundo pressupostos de qualidade obteve resultados notórios, na Conferência Nacional de Educação de 2010. O CAQ foi mencionado por inúmeros atores e recebeu ênfase no documento final da conferência. Segundo Araújo (2016) o instrumento foi inserido como alternativa capaz de equacionar os desequilíbrios regionais na oferta de educação básica e de aumentar o investimento em manutenção e desenvolvimento do ensino. Para tanto, o autor destaca quatro medidas aprovadas na conferência:

a) Necessidade de se tomar como referência o maior per capita existente no País, com o objetivo de unificar o valor aluno/a por ano executado no Brasil, acabando com as desigualdades por Estado;

b) O Fundeb reformatado deveria ter como referência o CAQ, nivelando todos os CAQs, a partir do valor máximo alcançado e praticado nos estados com maior arrecadação;

c) Extinção do sistema de balizas que limitam os fatores de ponderação do fundo a uma escala de 0,7 a 1,3. Esta medida é imprescindível para substituir a atual perspectiva do gasto-aluno/a/ano ou custo-aluno/a/ano existente no fundo, por uma política de custo-aluno/a-qualidade.

d) A complementação da União ao Fundeb deveria avançar imediatamente valores de transferência equivalentes a 1\% do PIB/ano (ARAÚJO, 2016, p. 170).

No Conselho Nacional de Educação as discussões também avançaram e proporcionaram a aprovação do Parecer CNE/CEB nº 8/2010, que estabelece normas para aplicação do inciso IX do artigo $4^{\circ}$ da Lei $n^{\circ}$ 9.394/96, adotando explicitamente o custo alunoqualidade como metodologia para regulamentação da previsão legal.

Nas etapas preparatórias da Conferência Nacional de Educação de 2014 e na tramitação do Plano Nacional de Educação (PNE) no Congresso Nacional o custo alunoqualidade e suas derivações foram objeto de ampla discussão, na Carta-Compromisso pela Garantia do Direito à Educação de Qualidade: uma convocação aos futuros governantes e parlamentares do Brasil, lançada em 31 de agosto de 2010, o CAQi é apresentado como um dos quatro compromissos fundamentais a serem implementnados e cumpridos, a nota técnica “Por que 7\% do PIB para a educação é pouco?”, publicada em agosto de 2011 pela Campanha Nacional pelo Direito à Educação, utiliza o CAQi como justificativa para o aumento da aplicação em manutenção e desenvolvimento do ensino e na nota técnica da Associação Nacional de Pesquisa em Financiamento da Educação (Fineduca), "Por que a União deve complementar o CAQi no PNE?”, o CAQ é referência para os cálculos que identificam a necessidade de ampliação da participação da União no financiamento da educação básica. Este processo assegurou que quatro estratégias sobre o Custo Aluno- 
Qualidade constassem na meta de financiamento do Plano Nacional de Educação, como pode ser observado abaixo:

20.6. no prazo de dois anos da vigência deste PNE, será implantado o Custo Aluno-Qualidade inicial (CAQi), referenciado no conjunto de padrões mínimos estabelecidos na legislação educacional e cujo financiamento será calculado com base nos respectivos insumos indispensáveis ao processo de ensino-aprendizagem e será progressivamente reajustado até a implementação plena do Custo Aluno Qualidade (CAQ);

20.7. implementar o Custo Aluno Qualidade (CAQ) como parâmetro para o financiamento da educação de todas etapas e modalidades da educação básica, a partir do cálculo e do acompanhamento regular dos indicadores de gastos educacionais com investimentos em qualificação e remuneração do pessoal docente e dos demais profissionais da educação pública, em aquisição, manutenção, construção e conservação de instalações e equipamentos necessários ao ensino e em aquisição de material didáticoescolar, alimentação e transporte escolar;

20.8. o CAQ será definido no prazo de três anos e será continuamente ajustado, com base em metodologia formulada pelo Ministério da Educação (MEC), e acompanhado pelo Fórum Nacional de Educação (FNE), pelo Conselho Nacional de Educação (CNE) e pelas Comissões de Educação da Câmara dos Deputados e de Educação, Cultura e Esportes do Senado Federal $[\ldots]$

20.10. caberá à União, na forma da lei, a complementação de recursos financeiros a todos os estados, ao Distrito Federal e aos municípios que não conseguirem atingir o valor do CAQi e, posteriormente, do CAQ (BRASIL, 2014b).

A ascensão do conceito de Custo Aluno-Qualidade e todos os critérios para sua mensuração atingiram o seu ápice com o PNE. Todavia, a falta de regulamentação definitiva do mecanismo contribui para que novas formulações surjam no cenário educacional. Na etapa nacional da Conferência Nacional da Educação (CONAE) de 2014, a concepção do Custo Aluno-Qualidade já continha novos elementos em disputa e, para os participantes da conferência o mecanismo deveria considerar:

os impactos da desigualdade social e regional nas práticas pedagógicas; os contextos culturais nos quais se realizam os processos de ensino e aprendizagem; a qualificação, os salários e a carreira dos profissionais da educação; as condições físicas e equipamentos das instituições educativas; o tempo diário de permanência do/da estudante na instituição; a gestão democrática; os projetos político-pedagógicos e planos de desenvolvimento institucionais construídos coletivamente; o atendimento extraturno aos/às estudantes e o número de estudantes por professor/a na escola em todos os níveis, etapas e modalidades (FÓRUM NACIONAL DE EDUCAÇÃO, 2015 p. 67).

Ao considerar os insumos e processos como centrais para a oferta de educação de qualidade os autores dão importância para remuneração e planos de carreira dos profissionais da educação, a infraestrutura das escolas, aos materiais pedagógicos, ao limite de número de 
estudantes por sala de aula, a formação inicial e continuada dos professores. Todavia, desconsideram os problemas de gestão tanto para aquisição de bens e serviços como para induzir sistemas de motivação dos servidores e funcionários para melhoria da oferta do ensino. E mais, o avanço das políticas educacionais parte do pressuposto de um contínuo aumento de recursos investidos na área educacional.

\subsection{Considerações sobre qualidade da educação}

A disputa pelo conceito de qualidade da educação vem assumindo contornos mais definidos entre os dois grupos citados no início deste capítulo, neste momento de acirramento de posições políticas, não há perspectiva de que uma tendência anule a outra, pois ambas estão se consolidando progressivamente neste cenário. No entanto, há possiblidades de desequilíbrios, em que determinado grupo ganhe projeção.

Se por um lado, temos o fortalecimento de um grupo que compreende educação de qualidade como resultados em exames estandardizados, sustentando o discurso de que as medidas para ampliar os resultados das provas seriam o melhor caminho para se percorrer, intensificando uma estratégia imediatista, que cobra por resultados de curto prazo sem se preocupar com problemas estruturais que impactam a educação brasileira.

Por outro, a estratégia do grupo que pensa nos insumos e processos que perfaz um caminho mais longo, envolvendo inúmeros interlocutores, em especial, sindicatos e movimentos sociais, apoia-se em um padrão de investimento em educação descolado do estágio de desenvolvimento do país, ou seja, o aporte de novos recursos exigidos para ampliar a qualidade das estruturas físicas das escolas, e ainda, possibilitar a melhoria das condições de trabalho com remuneração adequada teria impactos relevantes no PIB, e para se efetivar inauguraria um estágio de pleno conflito político por recursos, em que, haveria necessidade de ampliar a carga tributária, com a adoção de medidas que aumentem a apropriação do Estado frente às famílias e empresas ou anular outras políticas públicas que não sejam educacionais. Este conflito, que de tempos em tempos ganha intensidade, se mostra desfavorável aos trabalhadores nas atuais circunstâncias.

Daine Ravitch, uma das vozes mais conhecidas no campo educacional dos EUA, crítica das reformas norte-americanas que canonizaram os testes padronizados, o modelo de mercado na gestão escolar e as políticas de responsabilização docente, afirma que: 
Os fundamentos de uma boa educação serão encontrados na sala de aula, em casa, na comunidade e na cultura, mas os reformadores do nosso tempo continuam a procurar por atalhos e respostas rápidas. Desvinculadas de qualquer filosofia genuína da educação, as atuais reformas irão nos desapontar, assim como fizeram outras no passado. Nós iremos, com o tempo, vê-las como distrações, desvios equivocados e oportunidades perdidas. É tempo de reconsiderar não apenas os detalhes das atuais reformas, mas também a nossa própria definição de reforma (RAVITCH, 2011, p 251).

Deste modo, o CAQ está situado em sentido oposto às políticas de responsabilização que resumem a educação por meio do resultado das avaliações em grande escala. Contudo, a sua origem na defesa da ampliação de recursos destinados à educação ganhou centralidade tal, que o dispositivo complexo e multifacetado é corriqueiramente reduzido a um índice de correção econômica. 


\section{A RETÓRICA SOBRE AS FONTES DE FINANCIAMENTO DO CUSTO ALUNO QUALIDADE-INICIAL}

O presente capítulo pretende discutir a viabilidade de implementação do indicador Custo Aluno-Qualidade como parâmetro para financiamento da educação por meio da política de fundos estabelecida pelo Fundo de Manutenção e Desenvolvimento do Ensino Fundamental e de Valorização do Magistério (Fundef) e sucedida pelo Fundo de Manutenção e Desenvolvimento da Educação Básica e de Valorização dos Profissionais da Educação (Fundeb).

Há convergência entre autores do campo de finanças educacionais de que o acréscimo de recursos para financiar as políticas públicas deveria ocorrer por meio do aumento da contribuição da União aos Estados e Municípios, este entendimento contribuiu para que parte significativa dos movimentos sociais, sindicatos e pesquisadores elaborassem formulações com impacto do lado da despesa da União.

A consolidação da interpretação de que a União deveria ampliar a sua participação no financiamento da Educação ocorreu ao longo dos debates sobre o Plano Nacional de Educação, sendo assimilado por parte expressiva dos atores que participaram das Conferências Nacionais de Educação, resultando na estratégia 20.10, a qual define que

caberá à União, na forma da lei, a complementação de recursos financeiros a todos os estados, ao Distrito Federal e aos municípios que não conseguirem atingir o valor do CAQi e, posteriormente, do CAQ (BRASIL, 2014b).

Entre as 12 estratégias definidas para ampliar o investimento público em educação pública de forma a atingir, no mínimo, o patamar de dez por cento do Produto Interno Bruto até 2014, há apenas duas que citam formas de ampliação de recursos: uma se refere à vinculação da parcela da participação no resultado ou da compensação financeira pela exploração de petróleo e gás natural com despesas em manutenção e desenvolvimento do ensino e a outra, já citada, do aumento da participação da complementação da União. Portanto, o esforço para ampliação do financiamento da educação estaria concentrado na União.

Esta definição impressiona, uma vez que, no campo educacional existe a formação de um consenso sobre a criação um Sistema Nacional da Educação que estabeleceria mecanismos institucionais de colaboração entre a União, o Distrito Federal, os Estados e os Municípios. 
Contudo este capítulo visa compreender quais as determinações foram construídas para sustentar a tese de que a União deveria ser, exclusivamente, responsabilizada pela ampliação do investimento na educação. O foco deste trabalho reside na produção acadêmica no campo de financiamento da educação, concentrando-se na produção de Jorge Abrahão de Castro, Nelson Cardoso Amaral, José Marcelino Rezende Pinto (pesquisadores que participaram das audiências públicas sobre financiamento da educação no âmbito das discussões sobre o PNE na Câmara dos Deputados) e Luiz Araújo. Neste sentido não serão abordados aspectos sociológicos e políticos que podem ter contribuído para definição da concentração das responsabilidades em um ente federativo.

A análise será dividida em quatro determinações recorrentes: o baixo esforço da União para ampliação de recursos; os comparativos internacionais de investimento em educação; as abordagens que defendem um papel preponderante da União para o enfrentamento das desigualdades regionais do país e; as afirmações em relação a carga tributária.

\subsection{Baixo esforço da União para ampliação de recursos}

A crítica da baixa participação da União no financiamento da Educação em relação ao total da despesa é sustentada pela análise da peça orçamentária. No orçamento de 2014 as despesas da função Educação representavam somente 4,2\% do total de despesas.

Todavia, a análise está amplamente comprometida devido à forma em que pactuamos os direitos sociais na constituição e o impacto da dívida pública no orçamento. Primeiro é importante destacar que nas funções sociais o maior gasto da União é com a Previdência Social $(21,81 \%)$ e diferentemente das políticas de Educação e Saúde, os gastos do Regime Geral de Previdência Social são pagos exclusivos pela União, os gastos previdenciários de Estados e Municípios cobrem apenas os servidores públicos. A representatividade da previdência social no orçamento deriva de dois elementos: o robusto sistema de proteção de social assegurado pela constituição e a centralização da Previdência Social em um único ente.

Peres e Santos (2019) apresentam que o percentual em relação ao PIB dos gastos federais com a função previdência cresceu de 4,98\% em 1995 para 8,54\% em 2014, percentual que supera a soma de todas as funções sociais. Para os autores esta elevação decorre de dois fatores:

Em primeiro lugar, a opção de atrelar a remuneração básica ao salário mínimo permitiu valorizar as aposentadorias e benefícios assistenciais vinculados ao piso. Por outro lado, o envelhecimento populacional, com aumento da expectativa de vida dos mais idosos, mantém beneficiários 
recebendo por mais tempo recursos da previdência. Esses fatores tornaram essa função, isoladamente, o principal gasto social do governo. Esses mecanismos permitiram atenuar a desigualdade entre as camadas mais pobres da população, em especial na área rural (Helfand et ali, 2009), e de forma geral entre os beneficiários do Regime Geral de Previdência Social (PERES; SANTOS, 2019)

$\mathrm{Na}$ sequência surgem os gastos com Saúde (R \$ 93,8 bilhões) e Educação (R $\$$ 91,7 bilhões), portanto, com a exceção da Previdência social não há um descolamento do gasto social referente às outras funções.

$\mathrm{O}$ que nos leva à discussão do maior gasto do orçamento federal, a dívida pública. $\mathrm{Na}$ Lei Orçamentária Anual de 2014 a previsão de gasto da União com pagamento de juros e encargos da dívida era de R $\$ 189$ bilhões (10,9\% do orçamento) e com amortização da dívida de R $\$ 812$ bilhões, correspondendo a 46,7\% dos recursos da União, juntos representam mais da metade do gasto público.

A dívida pública em si não representa um problema para as nações, pois é por meio dela que os países conseguem captar recursos para realizarem investimentos necessários ao desenvolvimento econômico e social. No entanto, no caso brasileiro, o pagamento de altas taxas de juros aliado com a redução do prazo de vencimentos dos títulos públicos gera um alto custo de rolagem da dívida, o que prejudica o investimento público (BASTOS, 2016).

Também é importante recordar que depois da promulgação da lei de responsabilidade fiscal, e da regulamentação por meio da Resolução no 43 de 2001 do Senado Federal, os Estados e Municípios foram proibidos de emitir títulos públicos, o que minou a capacidade de investimento dos Estados e das capitais. Ao perderem a possibilidade de rolagem da dívida pela emissão de títulos, os entes subnacionais precisaram comprometer parcelas de até $12 \%$ da receita corrente líquida com amortização e pagamento de juros. Desta maneira, a União reforçou a sua posição de maior responsável pelo investimento público.

Sobre a questão da dívida federal é importante registrar a receita com a emissão de títulos. Na peça orçamentária de 2014 a previsão de arrecadação era de $\mathrm{R} \$ 850$ bilhões com operações de créditos (48,9\%), sendo R 654 bilhões com a emissão de títulos de responsabilidade do Tesouro Nacional para o refinanciamento da dívida. Portanto, no orçamento federal a dívida pública é a despesa e a receita (emissão de títulos) mais representativa, e em qualquer debate sobre alocação dos recursos do orçamento da União a dívida pública terá um papel central tanto do lado da despesa como da receita.

Ao considerar que parte significativa da receita de operações de crédito é utilizada para rolagem da dívida pública e para parcos investimentos em infraestrutura e de que quase a totalidade da receita de contribuições é destinada para assegurar as políticas de seguridade 
social, nos resta a expansão do gasto educacional por meio da receita de impostos, sendo que $18 \%$ deste recurso já é vinculado para manutenção e desenvolvimento do ensino.

Outra forma de crítica sobre a baixa participação da União no gasto público é decorrente da observação das tabelas oficiais do INEP, que consolidam o investimento em educação pública segundo cada ente. Pinto, Cara e Araújo (2013) citam os dados referentes ao ano de 2009, em que para "cada R \$ 1,00 investido em educação pública, o Governo Federal contribui apenas com R \$ 0,20, contra R\$ 0,41 dos 26 Estados e do Distrito Federal e R \$ 0,39 dos Municípios" e sintetizam o dado com a seguinte análise: "o ente federado que mais arrecada, possuidor de mais da metade da receita tributária líquida, é aquele que menos contribui com a educação".

O Comunicado 124 do Ipea (2011) traz parte da resposta sobre esta questão. Para tanto elabora uma evolução histórica do investimento e demonstra que ocorreu um aumento real do gasto em educação realizado pelas três esferas de governo entre 1995 e 2009, "saindo de $\mathrm{R} \$ 73,5$ bilhões para $\mathrm{R} \$ 161,2$ bilhões, um crescimento real de 119,4\% em 15 anos, equivalente a 5,9\% ao ano". Salienta também que o aumento dos gastos em proporção do PIB saiu do patamar de $4 \%$ para $5 \%$ no período, um crescimento de $25 \%$ que foi aferido nos últimos anos do estudo, de 2005 a 2009.

Em alusão à participação de cada ente no investimento em educação pública a análise do IPEA é categórica ao atribuir este crescimento a estrutura legal de financiamento e de competências, como podemos verificar no trecho abaixo:

Essa ampliação, entretanto, não significou necessariamente um aumento da capacidade exclusiva do município em financiar as ações educacionais. De um lado, ela reflete o aumento de recursos em poder dos municípios, resultante da política de priorização do ensino fundamental e a estrutura legal de financiamento e de competências, que em grande medida delineou a repartição do orçamento educacional (IPEA, 2011, p. 12).

$\mathrm{O}$ arcabouço institucional em relação ao financiamento da educação transferiu competências e recursos para Estados e Municípios, se por um lado, os Estados ficaram com a competência exclusiva do ICMS, que corresponde sozinho a $6,8 \%$ do PIB, sendo o imposto com maior arrecadação no sistema tributário, por outro os municípios foram beneficiados com as transferências constitucionais, como o Fundo de Participação dos Municípios e as cotasparte do ICMS e do IPVA.

Vale ainda destacar que a análise de Pinto, Cara e Araújo (2013) consideram a receita da União antes de computar as transferências entre os entes, ou seja, considera a receita bruta dos entes sem as deduções que são devidas, e do lado da despesa faz o inverso ao considerar o 
gasto final sem analisar a fonte de recurso que custeou as despesas de Estados e Municípios, de tal modo, a receita apurada da União não corresponde a recursos disponíveis para o gasto em política social, e do lado da despesa, os gastos de Estados e Municípios não são custeados exclusivamente com recursos próprios.

\subsection{Desvinculação de Receitas da União (DRU)}

Em artigos do campo de financiamento da educação está presente a crítica sobre a forma em que a União cumpriu a aplicação de dezoito por cento da receita resultante de impostos em manutenção e desenvolvimento do ensino. Parte considerável da literatura criticou o desvio finalidade de $20 \%$ dos recursos decorrentes da Desvinculação de Recursos da União (DRU), que substituiu o Fundo de Estabilização Fiscal, que por sua vez, havia sucedido o Fundo Social de Emergência, criado em 1994 como um instrumento transitório. De provisório somente os governantes, pois o mecanismo foi reeditado ${ }^{13}$ seguidas vezes.

A DRU impactou diretamente o volume de recursos que deveriam ser destinados às políticas educacionais, sem sombra de dúvidas o mecanismo representou um retrocesso em relação às vinculações de impostos e transferências constitucionais à manutenção e desenvolvimento do ensino (MDE), e ainda, permanece como um entrave para outras políticas sociais, em especial para seguridade social.

Entretanto, a incidência da Desvinculação das Receitas da União nas receitas vinculadas a MDE apresenta uma trajetória descendente iniciada em 2003. A Emenda Constitucional $n^{\circ} 42$ de 2003, foi uma das emendas constitucionais que estendeu o prazo da DRU, no caso até dezembro de 2007. Porém, definiu que não seria reduzida da base de cálculo as transferências aos Estados, ao Distrito Federal e aos Municípios, o impacto da medida atingiu especialmente duas transferências, o Fundo de Participação dos Munícipios (FPM) e o Fundo de Participação dos Estados (FPE), com o fim da restrição os fundos iniciaram 2004 com um acréscimo de 20\%, o aumento impactou diretamente nos valores disponíveis para educação, pois $25 \%$ dos impostos e transferências dos Estados, do Distrito Federal e dos Municípios são destinados à manutenção e desenvolvimento do ensino (MDE). A regularidade das transferências aos entes federados reestabelece a previsão de aplicação de recursos na educação prevista pela Constituição Federal, o que privilegia especialmente os entes das regiões Norte e Nordeste dependentes das transferências federais.

\footnotetext{
${ }^{13}$ A última reedição ocorreu em setembro 2016 com a Emenda Constitucional 93/2016.
} 
Importante destacar que tal medida não aumentou os gastos diretos da União com educação, mas reforçou o pacto federativo ao não deduzir as transferências destinadas aos demais entes. Na época, ainda estava em vigência o Fundef que financiava o ensino fundamental, assim, a liberação integral do FPM e FPE possibilitou a ampliação do investimento na expansão de matrículas no ensino médio e na educação infantil.

Porém a DRU ainda capturava recursos da União que seriam destinados à MDE, o dispositivo reduzia em $20 \%$ a base de cálculo para a aplicação direta dos $18 \%$ da União, a exclusão deste mecanismo ocorreu com a aprovação da Emenda Constitucional no 59/2009, que reduziu progressivamente o percentual capturado pela DRU, para 12,5\% em 2009, para 5\% em 2010 e a zero em 2011.

A conquista não é desprezível se tratando do orçamento federal, a luta dos movimentos sociais, sindicatos e intelectuais para derrubada do dispositivo ultrapassou uma década, mas o fim da DRU não consta na maioria das análises sobre a participação da União no financiamento da educação.

\subsection{Complementação da União por meio do Fundeb}

Parte dos pesquisadores identifica problemas na complementação da União ao Fundeb, a crítica é de que o atual modelo de ajuste não possui uma regra que estabeleça um repasse da União segundo critérios de qualidade, ou seja, o valor mínimo nacional seria definido pelos valores disponíveis da União, sem qualquer cálculo no intuito de aferir se este valor mínimo de fato representa uma educação de qualidade.

Para tanto há inúmeros cálculos que sugerem a ampliação dos valores dispendidos com a complementação da União. Pinto, Cara e Araújo (2013) argumentam que com base no ano de 2012 seria necessário um aporte de R\$ 46 bilhões para o financiamento da educação básica, a complementação da União saltaria do patamar $0,2 \%$ do PIB para 1,05\% do PIB, isto considerando apenas as matrículas daquele ano, sem contabilizar a necessidade de expansão da educação infantil, do ensino médio e da alfabetização de adultos. Em outra avaliação (CARA e ARAÚJO, 2011) os autores estimam que o acréscimo para o atendimento das metas do PNE será da ordem de 5,4\% do PIB, sendo que a maior parte dos recursos se refere à expansão de matrículas e aumento da qualidade da Educação Básica.

A regra de complementação da União ao Fundeb passou a corresponder ao equivalente a $10 \%$ dos recursos destinados ao fundo pelos Estados, Distrito Federal e Municípios a partir de 2010, uma subvinculação que injetou $\mathrm{R}$ \$ 13,3 bilhões em 2015, contra um dispositivo do 
Fundef que aplicou pouco mais de R\$ 515 milhões em 2006, em valores reais ${ }^{14}$, ou seja, em nove anos os valores transferidos por meio da complementação da União correspondem a mais de 24 vezes ao que era investido até 2006, poucas políticas públicas tiveram uma trajetória de crescimento desta envergadura, sustentar o atual formato de contribuição da União já seria uma árdua tarefa, aumentar o padrão de investimento será ainda mais difícil. Associado a este movimento há o fato de que, no mínimo, $70 \%$ dos recursos da complementação da União deveriam ser novos, ou seja, que a União não poderia utilizar os $18 \%$ vinculados a MDE, tal restrição foi introduzida na regulamentação do Fundeb.

\subsection{Contribuições Sociais}

Após a redemocratização e a promulgação da Constituição Federal, com as determinações sobre a competências dos entes em relação às políticas sociais e as novas regras de repartição dos tributos, a receita disponível da União foi reduzida em 9,3 pontos percentuais, transferindo recursos para estados e munícipios (PERES; SANTOS, 2019)

Com a receita de impostos vinculada a políticas sociais e aos fundos de participação dos estados e municípios, a União utilizou da criação das contribuições para aumentar a arrecadação. Peres e Santos (2019) analisam que:

Para além das demandas sociais que pressionavam o orçamento federal, a instabilidade monetária e o endividamento externo e interno estimulavam medidas de ajuste fiscal. A União instituiu novas contribuições federais ou elevou a receita de contribuições já existentes (COFINS, CSLL, PIS, PASEP, entre outras) de forma a compensar as perdas tributárias constitucionais, elevar a arrecadação federal e interromper a trajetória de queda da receita disponível observada desde os anos 1980 (PERES; SANTOS, 2019).

Devido ao aumento de arrecadação com as contribuição parte da academia argumenta que a União deveria arcar com novos investimentos na educação, as quais não são vinculadas aos repasses aos Estados e aos Municípios. Todavia, as contribuições sociais são destinadas ao custeio de atividades específicas, a sua criação atende a um fim determinado, diferentemente dos impostos que não possuem um fim específico.

No orçamento federal de 2014 a receita de contribuições representava $30 \%$ do total, quase o dobro da receita de impostos (17,9\% dos recursos). Todavia, dos R\$ 670 bilhões arrecadados com as contribuições, 93,7\% eram de contribuições destinadas à seguridade social (R\$ 628 bilhões) e entre os 6,3\% de contribuições restantes estava em primeiro lugar à

\footnotetext{
${ }^{14}$ Valores a preços de dezembro de 2015, atualizados pelo IPCA-IBGE.
} 
contribuição do salário-educação, com R \$ 18,2 bilhões, recursos estes destinados para despesas educacionais. Portanto, neste caso há uma questão de conflito distributivo de dois direitos constitucionais, educação e seguridade social, uma possível vinculação destes recursos para manutenção e desenvolvimento de ensino limitaria o financiamento de políticas de saúde, previdência e assistência social.

\subsection{Comparativos internacionais de investimento em educação}

Determinados estudos utilizam comparativos internacionais para justificar o aumento do investimento público em educação. O percentual de investimento em educação em relação ao PIB não difere tanto dos demais países, Amaral (2015) apresenta que o país investiu 5,08\% do PIB em 2011, enquanto o bloco $^{15}$ dos países da Organização para a Cooperação e Desenvolvimento Econômico (OCDE) investiram 5,17\%. Em relação aos países que compõem o bloco dos BRICS ${ }^{16}$ somente a África do Sul investiu percentual superior ao Brasil, com investimento de 5,4\%. No entanto, ao equacionar o valor aplicado em educação em relação à população em idade escolar o resultado demonstra a distância do país em relação ao bloco da OCDE. Com base nesses números o autor conclui que para o Brasil atingir o valor aplicado por pessoa em idade educacional, ajustado em dólares segundo o poder de paridade de compra, deverá multiplicar 4,2 vezes o atual investimento em educação, isto implicaria na necessidade de um investimento público de $21,3 \%$ do PIB em despesas educacionais.

Nelson Cardoso Amaral (2015) reconhece a impossibilidade do Brasil investir tais valores, mas o diagnóstico permanece, inclusive utiliza o cálculo como forma de pressão para que o gasto educacional alcance padrões intermediários, como $10 \%$ do PIB. Na introdução do documento o autor elenca três circunstâncias necessárias para atingir o patamar de financiamento per capita do bloco da OCDE, que seriam:

estabilidade da população total, com a diminuição do quantitativo de crianças e jovens em idade educacional; crescimento, que inclui o Produto Interno Bruto (PIB), no contexto do capitalismo mundial como está estruturado; e a consequente diminuição da desigualdade social existente (Amaral, 2015, p 67).

Porém, estes elementos não são desenvolvidos no artigo, ao contrário, é apontado como forma de superação o aumento do investimento em educação. A importância do crescimento econômico com distribuição de renda, a forma em que o país está inserido na

\footnotetext{
${ }^{15} \mathrm{O}$ autor desconsiderou o Chile, a Hungria, o México e a Turquia, países que compõe a OCDE. Para o estudo foram considerados somente os países em "uma situação cristalizada no contexto mundial de estruturação da sociedade no modo capitalista de produção", denominando o conjunto destes países como "bloco OCDE".

${ }^{16} \mathrm{O}$ bloco é composto por Brasil, Rússia, Índia, China e África do Sul.
} 
economia global, a estrutura desigual de distribuição de renda e as variações demográficas nas próximas décadas são substituídas por uma crença de que o aumento do investimento em educação teria prioridade, reforçando um imaginário de que o investimento em educação proporcionaria uma transformação social.

Por outro lado, para Ricardo Paes de Barros (2018) o gasto total com educação em relação ao PIB do Brasil é equivalente ao dos países membros da OCDE, sobre o comparativo per capita entre os países o autor responde com outra pergunta: "O que é mais importante: reduzir a desigualdade em gasto por aluno ou a desigualdade na eficiência do gasto?". Deste modo teríamos dois caminhos, ampliar os recursos com políticas educacionais para equiparar o investimento por aluno ou introduzir melhorias de gestão. Para tanto Barros (2018) compara o gasto por aluno do SIOPE com resultado do Ideb nas séries iniciais do ensino fundamental e afirma que $81 \%$ da desigualdade existente entre as escolas deriva da ineficácia da gestão, apenas 19\% seriam decorrentes da insuficiência de recursos.

Enquanto para Amaral é necessário cumprir três requisitos para ampliar o financiamento para Barros os recursos dispendidos com políticas educacionais seriam responsáveis pelo desenvolvimento nacional, no artigo publicado sobre os determinantes do desempenho educacional no Brasil, Barros et al. (2001) explicitam o alinhamento a teoria do capital humano.

No Brasil, a combinação de um sistema educacional público precário com graves imperfeições no mercado de crédito tem feito com que o nível de investimentos em capital humano esteja sistematicamente abaixo dos padrões internacionais [ver Behrman (1995a e b), Duryea (1997) e Barros e Mendonça (1997b)]. Este fato surpreende na medida em que todas as estimativas existentes para as taxas de retorno desse tipo de investimento apresentam valores bastante atraentes.

Mais preocupante que o subinvestimento em capital humano é o fato de este ser tão mais acentuado quanto mais pobre é a família. Como o grau de pobreza de um indivíduo é fortemente determinado por seu nível educacional, essa natureza diferenciada do subinvestimento em educação leva à transmissão intergeracional da pobreza (BARROS; MENDONÇA; SANTOS; QUINTAES, 2001, p 1).

Nelson Cardoso Amaral e Ricardo Paes de Barros possuem referencias teóricos distintos e se diferenciam em relação ao diagnóstico sobre a necessidade de novos aportes de recursos para garantir uma educação de qualidade, ambos utilizam os indicadores da OCDE sobre financiamento da educação brasileira para justificarem posições antagônicas, isto demonstra como determinados dados quantitativos são insuficientes para compreender a realidade nacional. 


\subsection{Enfrentamento das desigualdades regionais do país}

Entre os intelectuais citados neste artigo existe a compreensão de que o Estado necessita atuar em inúmeras frentes para possibilitar melhores condições de vida aos seus cidadãos, mas a estratégia de ampliação dos gastos educacionais torna-se prioridade absoluta como exposta no seguinte trecho:

Embora seja errôneo afirmar que o financiamento adequado da educação pública resolva sozinho o conjunto avassalador de problemas educacionais brasileiros, é certo afirmar que sem ele nada poderá ser feito (CARA e ARAÚJO, 2011, p. 4).

Isto representa uma ideia de fácil assimilação pelo conjunto da sociedade e de ampla aderência, pois as resistências encontradas para expansão do gasto educacional somente são evidenciadas pelos representantes do poder público. O cálculo do CAQ ganhou notoriedade dentro deste escopo, ao mensurar um padrão de qualidade nacional, os pesquisadores abdicam da atual estrutura de financiamento estabelecida por meio fundos estaduais, o cálculo institui um valor de investimento nacional segundo fatores mínimos de qualidade, no entanto, o grande número de diretrizes implica em um valor significativamente superior ao atualmente praticado, deste modo, caso o CAQ seja efetivado, todos os recursos da educação básica seriam destinados para cumpri-lo, dificilmente teríamos estados com um investimento por aluno diferente.

Para Pinto, Cara e Araújo (2013) este seria o efeito equalizador do CAQi,

com sua implantação todas as unidades da federação, no âmbito da atual política de fundos, teriam ao menos no Ensino Fundamental e na Pré-Escola, valores disponibilizados por aluno próximos àqueles praticados em São Paulo (PINTO, CARA e ARAÚJO, 2013, p. 6).

A definição parece interessante do ponto de vista de justiça regional, mas descola de uns dos pressupostos do indicador - os custos efetivos de uma educação de qualidade, infelizmente os custos reais para uma educação segundo critérios de qualidade seriam diferentes, há distinções importantes nos custos dos insumos entre os Estados, unificá-los em um valor único nacional dificultaria a gestão educacional em Estados com os maiores custos, pois estes não teriam condições de aportar mais recursos, haveria desequilibro do financiamento da educação.

Há uma distinção entre atuar para diminuir desigualdades regionais e financiar com valores iguais todos os entes da federação, a atual política de financiamento da educação possibilitou avanços expressivos por meio do Fundeb, especialmente pela complementação da União, que aportava importantes quantias nos fundos estaduais com o menor valor aluno, isto 
implicou em melhorias substanciais, com destaque para remuneração dos profissionais do magistério. Os Estados que recebem a complementação da União oferecem salários superiores ao dispendido com os profissionais nas redes estaduais do Sul e do Sudeste, como pode ser observado na tabela 11, que sintetiza o salário inicial dos profissionais do magistério com Licenciatura Plena nas redes estaduais.

Tabela 11 - Salário Base dos Profissionais do Magistério com Licenciatura Plena, fevereiro de 2016

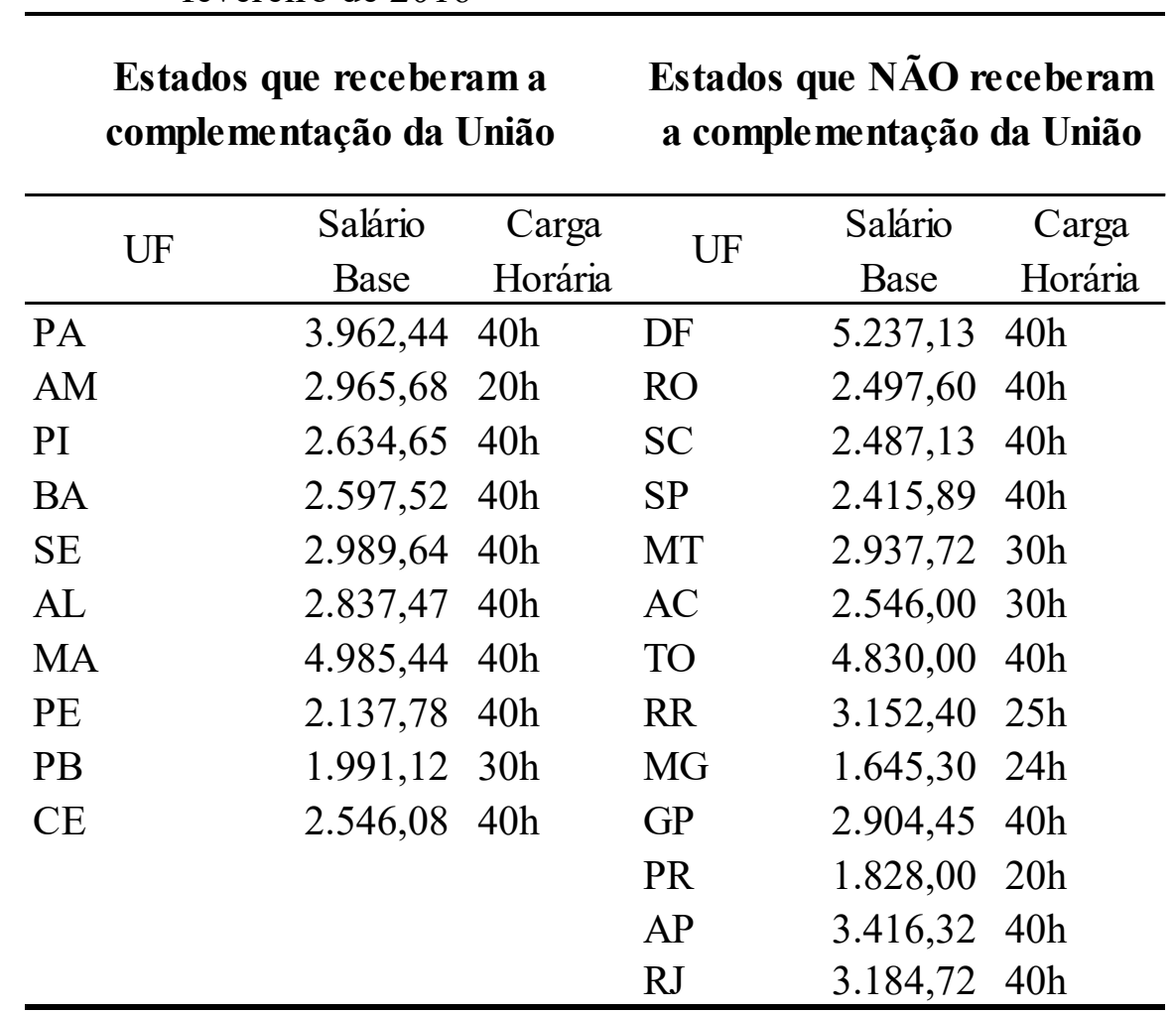

Fonte: CNTE, entidades filiadas.

O aumento do gasto com a remuneração dos profissionais do magistério ocorre tanto pelo aumento da receita como pela possibilidade de controle dos custos dos demais insumos da educação básica. Os estados que receberam a complementação da União registraram taxas de crescimento dos recursos vinculados ao ensino, expressivamente, superiores a inflação do período, como os custos de bens e serviços permaneceram próximos à inflação, houve espaço para destinação de mais recursos para remuneração de pessoal. Estamos longe de eleger que esse efeito gerou redes de ensino de excelência, mas o dispositivo do CAQ ao distribuir recursos segundo um valor único nacional, tende a fortalecer os Estados com os menores custos reais, enquanto intensifica a precarização das relações de trabalho nos Estados com custos mais elevados.

A potencialidade de redução de desigualdades regionais por meio do financiamento da educação básica pode ser medida por meio de critérios objetivos, vinculados diretamente com 
a educação, como acesso, infraestrutura escolar e remuneração dos trabalhadores da educação. A alteração de índices de atividade econômica, índice de desigualdades sociais ou de desenvolvimento econômico deriva de uma série de variáveis que o sistema escolar está submetido. Deste modo, o sistema escolar não possui condições de alterar uma profunda estrutura econômica de desigualdade social.

\subsection{A Carga Tributária Bruta}

Resta-nos discutir um último argumento no qual a carga tributária brasileira comportaria o aumento da despesa com educação em $1 \%$ do PIB, a base geralmente é a comparação da carga tributária bruta em relação ao PIB, e depois a participação da União na carga tributária. Para ilustrar utilizemos os $\operatorname{dados}^{17}$ do exercício de 2014, no qual a carga tributária bruta foi de $33,47 \%$ do PIB, sendo que $68,47 \%$ dos recursos foram arrecadados pela União, 25,35\% pelos Estados e 6,29\% pelos municípios. Isto posto, seria base suficiente para justificar a participação da União no financiamento da educação básica.

Entretanto é necessário fazer uma diferenciação entre carga tributária bruta e carga tributária líquida, pois a carga tributária líquida reflete melhor o impacto da política fiscal sobre a receita disponível do setor público. A carga tributária líquida desconta todas as transferências para previdência, assistência social e subsídios (TAPS) que são transferidas diretamente para as famílias ou empresas (IPEA, 2009). Tais recursos não fazem parte da gestão orçamentária do governante, pois são instrumentos de proteção e inclusão social das famílias ou incentivos ao setor produtivo para patrocinar o desenvolvimento do país, portanto estes recursos não estão à disposição para os entes, são obrigações a serem cumpridas pelo governo (IPEA, 2009).

Ao descontar as TAPS a carga tributária vai de 33,47\% do PIB (carga tributária bruta) para 17,39\% (carga tributária líquida), sendo que $81,2 \%$ das TAPS são da União. Neste percentual ainda caberia à dedução do gasto com pagamento de juros e amortização da dívida pública, e ainda as deduções decorrentes de transferências da União aos Estados e Municípios.

Após as deduções, que devem ser operadas por qualquer governante a frente do Estado, a distância da União em relação aos demais entes é diminuta perdendo significado este embate entre eles, pois as competências para gerir as políticas sociais estão entrelaçadas e não há espaço orçamentário sem conflito político.

\footnotetext{
${ }^{17}$ MINISTÉRIO DA FAZENDA. Análise dos Tributos e Bases de Incidência. Carga Tributária no Brasil. Brasília, 2014.
} 
Neste sentido, o estudo de Castro (2014) que identifica o núcleo da política social nos traz importante subsídio. O artigo identifica que as políticas de Previdência Social Geral, Benefícios a Servidores Públicos, Saúde, Assistência Social, Educação, e Habitação e Saneamento corresponderam a 95\% do gasto da política social do Estado brasileiro, no período de 1995 a 2010, com crescimento significativo no período, conforme gráfico 1.

Gráfico 1 - Gasto público social por políticas de governo em \% do PIB - 1995, 2005 e 2010

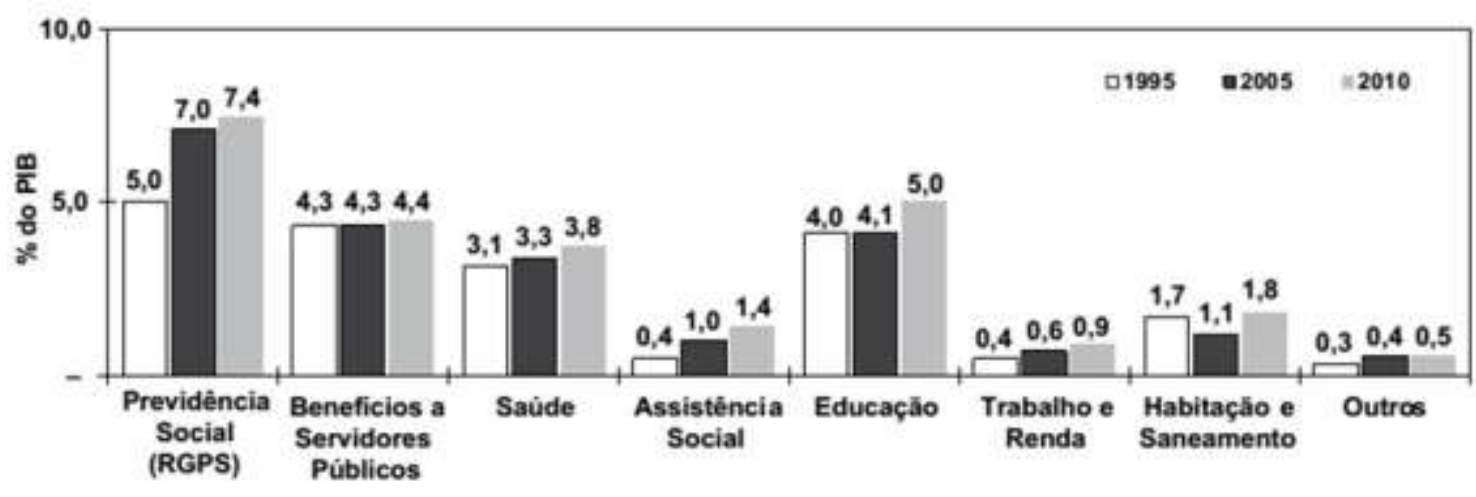

Fonte: Castro (2008) e Sistema integrado de dados Orçamentários (SIDOR) do MPOG.

$\mathrm{O}$ autor apresenta que todas as áreas tiveram acréscimos de recursos no período, e ainda, sustenta que este é um dos elementos que pressionaram e ampliaram a carga tributária. Por fim, analisa que,

se os interesses que giram em torno das políticas educacionais não olharem para esse quadro, será difícil imaginar soluções para a área. O diálogo deve ser construído com esse conjunto de interesses sociais, porque todos são atores nacionais (CASTRO, 2014, p. 188).

Peres e Santos (2019) explicitam a importância deste diagnóstico ao elegerem três premissas para análise do orçamento da União:

A primeira é de que o orçamento público é objeto de conflitos distributivos entre distintos interesses. A segunda é de que esta disputa não ocorre no vazio. Diferentemente, é afetada por regras de formatação orçamentária que, por sua vez, expressam motivações. Além disto, escolhas prévias criam uma dinâmica independente, reduzindo a margem de escolha dos governos presentes. A despeito disto, preferências partidárias programáticas podem ser visualizadas nas mudanças introduzidas na alocação orçamentária (PERES; SANTOS, 2019)

\subsection{Considerações sobre a ampliação da participação da União no financiamento da política educacional}

O debate sobre qualidade da educação e seu respectivo financiamento esteve pautado na estruturação de um fundo para melhor distribuição de recursos públicos. Porém, parte da 
literatura deste campo de pesquisa insere como eixo estrutural para melhoria da qualidade da educação a ampliação do aporte de recursos públicos para área.

A defesa do aumento de recursos para educação básica permanece mesmo depois da União acabar com a DRU, tanto das transferências constitucionais aos Estados e Municípios como dos recursos destinados à manutenção e desenvolvimento do ensino no âmbito da União, e da ampliação dos recursos destinados ao Fundeb através da complementação da União. Todavia, o diagnóstico mais conservador entre os pesquisadores deste campo é de que há necessidade da União acrescentar ao fundo de educação básica, no mínimo, o valor correspondente a $0,78 \%$ no PIB.

Tal avaliação pautada na ampliação da despesa não encontra respaldo na receita pública, esta dissertação tentou demonstrar que a abordagem de responsabilizar unicamente a União com o aumento do gasto público na área educacional não é uma tese com premissas fortes, e que dificilmente haverá a aumento do gasto da União neste contexto. Ainda mais com a Emenda Constitucional 95, aprovada pelo governo Temer, que restringe o aumento da despesa pública a inflação do ano anterior.

Entendendo como necessária a ampliação da despesa educacional para garantir condições mínimas de qualidade esta sessão procurou abordar de forma crítica as possibilidades de expansão da receita e da alocação da despesa pública. 


\section{O CAQI ENQUANTO POLÍTICA PÚBLICA: COMPOSIÇÃO DO CAQI EM PERSPECTIVA COMPARADA AO CUSTO ALUNO DA REDE MUNICIPAL DE SÃO PAULO.}

O trabalho desenvolvido por Denise Carreira e José Marcelino Rezende Pinto (2007) traz contribuições importantes para consubstanciar o Custo Aluno-Qualidade inicial (CAQi), amplamente discutido nas Conferências Nacionais da Educação e no PNE.

Inegavelmente o indicador sintético incluía inúmeras preocupações de educadores, movimentos sociais e organizações do terceiro setor, se consolidando ao ser assegurado por seguidas normas, em especial, no PNE. A ascensão foi tal, que o debate se encontrava nas condições objetivas para implementá-lo, se questionava quais as fontes para sustentá-lo e a forma que este esforço seria compartilhado entre os entes federativos. Este cenário começou a mudar com o agravamento da crise econômica em 2015, que impôs restrições financeiras para administração pública e solapou qualquer medida que aumentasse consistentemente o gasto público.

De acordo com SAVIANI (2017) a descontinuidade das políticas públicas é uma das características estruturais que operam na política educacional brasileira. Neste sentido a retirada do CAQi da agenda governamental do não é em si um evento inesperado. Contudo, este capítulo pretende analisar os aspectos metodológicos que fundamentaram o CAQi e identificar se as métricas adotadas pelos pesquisadores podem ser revisitadas nos estudos sobre financiamento da educação. Para tanto, na primeira do capítulo compreende-se quais são os determinantes de custos do CAQi, com os respectivos pesos de cada insumo em cada etapa de ensino e na segunda parte aborda-se os custos com manutenção e desenvolvimento do ensino na rede municipal da cidade de São Paulo.

\subsection{Determinantes de custos do CAQi}

Um aspecto importante é de que os custos são calculados por atribuição pelos pesquisadores, não houve coleta de dados em relação às despesas de cada insumo em escolas. O método consistia na definição hipotética de todas as despesas para manutenção e desenvolvimento do ensino de qualidade, e posteriormente a precificação. Os valores apresentados se referem ao ano de 2005, optou-se em manter os valores nominais por entender que o principal aspecto de observação se refere aos pesos relativos de cada componente. 
Carreira e Pinto (2007, p. 77) iniciaram os estudos com sete definições, que nomeiam como pontos de partida, os quais são:

1. Os valores do CAQ por etapas e modalidades, estabelecem um patamar mínimo de qualidade de educação e não um valor médio ou ideal, portanto, o mais adequado é defini-lo como Custo Aluno-Qualidade inicial, um primeiro passo decisivo rumo à qualidade que almejamos como a ideal.

2. O valor do CAQi é essencialmente dinâmico e tende a crescer à medida que melhora a qualidade da educação pública oferecida e conforme os padrões de exigência da população aumentam.

3. O valor do CAQi é calculado a partir dos insumos indispensáveis ao desenvolvimento dos processos de ensino e aprendizagem.

4. O valor do CAQi deve ser diferenciado em função dos diferentes níveis e modalidades de ensino.

5. O CAQi deve assegurar uma remuneração condigna aos profissionais do magistério, assim como aos demais trabalhadores em educação.

6. O CAQi deve considerar os parâmetros de infraestrutura e qualificação docente definidos pelo PNE.

7. O CAQi deve contribuir para o enfrentamento dos desafios de equidade existentes na educação brasileira.

Nos dois pontos de partida iniciais há dúvidas sobre a proposta. No primeiro ocorre uma tentativa dos autores de distanciar do rótulo de valores médios ou ideais. De pronto podese garantir que o CAQ não equivale a valores médios, pois não há coleta de dados para gerar uma pretensa média, os valores de cada insumo foram atribuídos pelos pesquisadores. Já em relação à representação ideal existe um esforço de definição técnica da cesta de bens e produtos e dos respectivos valores de cada insumo, além das decisões técnicas insere-se um artifício de linguagem ao incluir no termo "Custo Aluno-Qualidade" a palavra "inicial" para remeter que o índice não vislumbra identificar o custo ideal, mas um patamar mínimo de despesas para atingir uma educação de qualidade. Apesar do empenho em justificar as bases do CAQi como "não ideais" é notório que o mecanismo parte da definição de uma cesta básica de bens e serviços para cada etapa de ensino, somado a uma definição de preços única, sem qualquer relação com preço do bens e serviços nas localidades, dito isto, a própria metodologia apresenta argumentos suficientes para refutar o termo inicial.

O segundo ponto de partida cita que o CAQ é "essencialmente dinâmico e tende a crescer”, isto pressupõe que a cesta de bens e serviços seria revista após determinado período, mas não há explicações de como este mecanismo funcionaria.

Dito isto, parte-se para matriz do CAQi, que se constitui de quatro fatores relacionados à qualidade do ensino: etapas e modalidades, recortes de equidade, dimensões e insumos. 


\subsubsection{Etapas e Modalidades de Ensino}

Além das etapas e modalidades previstas na LDB o estudo considera a educação do campo como uma modalidade específica devido aos custos serem superiores aos das escolas no meio urbano, em especial, por causa do tamanho reduzido das escolas.

Em relação à educação especial houve a opção de considerar educação inclusiva que priorize o "atendimento de alunos portadores de necessidades especiais em escolas regulares, garantindo, não obstante, o atendimento adequado às suas especificidades”, porém os valores de custo não são mensurados. Segundo os autores o modo de considerar tal modalidade é via a contabilização em duplicidade desses alunos.

A educação destinada a jovens e adultos também não consta na matriz de cálculo do CAQi, contudo os pesquisadores afirmam que devem ser consideradas as recomendações dos Enejas (Encontros Nacionais de Educação de Jovens e Adultos) para que não haja diferenciação do valor gasto entre o aluno do ensino regular e o aluno de Educação de Jovens e Adultos (EJA). Outras modalidades citadas ao longo do estudo também não são referenciadas na matriz de cálculo, como educação indígena, a educação no campo de comunidades quilombolas, seringueiras e ribeirinhas e a educação profissional, nestes casos não há qualquer parâmetro para o cálculo dos valores por aluno.

O valor por aluno no ensino fundamental é medido tanto para séries iniciais como para séries finais, esta divisão também é utilizada para calcular os valores per capita no campo. Todavia, em relação ao ensino médio não há recorte entre urbano e rural, regra prevista no Fundeb.

Nota-se na Tabela 12 que o valor mais elevado por aluno se encontra na educação infantil, que registra um per capita de $\mathrm{R} \$ 4.139,00,140 \%$ maior que o índice básico mensurado nas séries iniciais do ensino fundamental. Dois elementos contribuem para este resultado, o número de alunos por turma e a jornada semanal. 
Tabela 12 - Número de alunos por turma, jornada semanal e valor do CAQi, segundo etapas e modalidade de ensino, 2005

\begin{tabular}{|c|c|c|c|c|c|}
\hline Etapas e Modalidades de Ensino & $\begin{array}{l}\text { Número } \\
\text { de Alunos } \\
\text { por Turma }\end{array}$ & $\begin{array}{l}\text { Jornada } \\
\text { Semanal }\end{array}$ & $\begin{array}{c}\text { Consta na } \\
\text { Matriz de } \\
\text { Cálculo } \\
\end{array}$ & CAQi & Índice \\
\hline \multicolumn{6}{|l|}{ Etapas de Ensino } \\
\hline \multicolumn{6}{|l|}{ Educação Infantil } \\
\hline Creche & 12 & 50 & Sim & $4.139,00$ & 2,4 \\
\hline Pré-escola & 22 & 25 & Sim & $1.789,00$ & 1,04 \\
\hline \multicolumn{6}{|l|}{ Ensino Fundamental } \\
\hline Ensino Fundamental Séries Iniciais & 25 & 25 & $\mathrm{Sim}$ & $1.724,00$ & 1 \\
\hline Ensino Fundamental Séries Finais & 30 & 25 & Sim & $1.697,00$ & 0,98 \\
\hline Ensino Médio & 30 & 25 & Sim & $1.746,00$ & 1,01 \\
\hline \multicolumn{6}{|l|}{ Modalidades de Ensino } \\
\hline Educação Especial & & & Não & & \\
\hline Educação de Jovens e Adultos & & & Não & & \\
\hline Educação Indígena & & & Não & & \\
\hline Educação Profissional & & & Não & & \\
\hline Educação do Campo & & & Sim & & \\
\hline Quilombolas, Seringueiras e Ribeirinhas & & & Não & & \\
\hline Séries Iniciais do Ensino Fundamental & 15 & 25 & Sim & $2.390,00$ & 1,39 \\
\hline Séries Finais do Ensino Fundamental & 25 & 25 & Sim & $2.319,00$ & 1,34 \\
\hline
\end{tabular}

Fonte: Cus to Aluno-Qualidade inicial: ruma à educação pública de qualidade no Brasil

Elaborado pelo autor

Para identificar o número de alunos por turma os pesquisadores utilizaram dois referenciais, a relação prevista no projeto original da LDB, substitutivo Jorge Hage, que estabelecia a relação aluno/professor de 20 na creche; 25 na pré-escola e alfabetização e de 35 nas demais séries, e o documento Subsídios para credenciamento e funcionamento de instituições de educação infantil, do MEC, em que orienta a formação de turmas de 6 a 8 crianças na idade de 0 a 1 ano, de 8 a 10 crianças de 1 a 3 anos, de 12 a 15 crianças de 3 a 5 anos e de 20 a 25 crianças para faixa etária de 5 a 6 anos. Por fim, os pesquisadores atribuíram o número médio de 12 crianças para creches e de 22 para pré-escolas. No Fundeb não há qualquer menção ao número de alunos por turma.

O outro ponto é em relação à jornada, nas creches a carga horária referenciada é de 50 horas semanais, o dobro das demais etapas de ensino. Deste modo, considera-se que a implementação da educação infantil seria por tempo integral de imediato enquanto nas demais etapas de ensino a jornada diária não ultrapassaria 5 horas.

Há uma grande preocupação em demonstrar que os custos por aluno nas creches são superiores às demais etapas de ensino. A priori o número de alunos por turma representa um fator estrutural, com baixa possibilidade de ampliação do atendimento de alunos por turma sem prejudicar a qualidade da educação, por outro lado, as demais etapas de ensino podem, 
progressivamente, aumentar a carga horária semanal. Em suma, caso a carga horária seja semelhante nas diversas etapas de ensino a diferença do custo per capita com alunos das creches em relação ao das séries iniciais do ensino fundamental se reduz de 140\% para 20\%.

Ademais o cálculo apresentado pelos pesquisadores mensura o atendimento em creches geridas diretamente pelo poder público, os autores não abordam os custos com creches em instituições comunitárias, confessionais ou filantrópicas sem fins lucrativos conveniadas com o setor público.

\subsubsection{Recortes de equidade e dimensões}

Os recordes de equidade e as dimensões são eixos da matriz do CAQi, ambos abordam aspectos a serem observador em termos de qualidade da educação, no entanto, possuem pouca relevância quando se trata especificamente do financiamento do ensino, as questões apresentadas não são mencionadas financeiramente, torna-se uma diretriz sem qualquer parâmetro para sua concretização. Neste ponto os formuladores da política mesclam equivocadamente fatores importantes a serem observados no âmbito da escola com métricas que serão adotadas em âmbito nacional para distribuição dos recursos da educação. O aporte serve para identificar o que os autores compreendem como qualidade da educação, sem qualquer efeito para composição do CAQi. Neste sentido, cabe apenas apresentar os conceitos.

Os recortes de equidade referem-se à desigualdade econômica, de gênero, raça/etnia, campo e cidade, localização regional e orientação sexual, que expressam processos históricos de discriminação, preconceito e exploração. As políticas educacionais não seriam suficientes para superação das relações de desigualdades, mas se articulariam para o enfrentamento das mesmas.

Os recortes de equidade tratam das desigualdades inerentes à realidade brasileira enquanto as dimensões tratam de aspectos intrínsecos às unidades escolares, sendo três dimensões: estética, ambiental e de relacionamentos. Em estética compreende-se "às condições do ambiente educativo que possibilitem prazer, criatividade, pertencimento", destacam-se aspectos como "a pintura e decoração do prédio, a existência de materiais para experiências artísticas, o contato com a produção artística da comunidade (local, nacional e internacional), a visita a espaços culturais”. Na dimensão ambiental pressupõe a inclusão dos estudantes e da comunidade escolar em ações de respeito pela natureza, que poderiam ser concretizados por meio do incentivo a criação de hortas comunitárias, reciclagem do lixo, realização de diagnóstico socioambiental da comunidade, dentre outras iniciativas. Por fim, a 
dimensão relacionamentos humanos sustenta a importância de a escola estimular a promoção de vínculos de interação e respeito à diversidade humana.

\subsubsection{Insumos}

Em insumos os autores tratam dos bens e serviços pertinentes para dar condições efetivas para uma educação de qualidade, que estão relacionados: i) as condições de estrutura e funcionamento; ii) a valorização das e dos profissionais; iii) a gestão democrática; e iv) ao acesso e permanência estudantil.

Nas condições de estrutura e funcionamento inserem-se a construção e conservação dos prédios, serviços de utilidade pública (água, energia, telefone), materiais de limpeza e escritório e manutenção e reposição de equipamentos.

Os custos em conservação predial foram estimados em $2 \%$ do valor da construção de unidades de educação infantil e de ensino fundamental nas séries inicias, e de 3\% para escolas de ensino fundamental séries finais e ensino médio. Além destes cálculos gerais há uma extensa lista de insumos que relaciona quais os equipamentos e materiais permanentes necessários, delineados por áreas, como esporte e brincadeiras, coleções e materiais bibliográficos, equipamentos para áudio, vídeo e foto, processamento de dados e, mobiliário e aparelhos em geral, com as respectivas quantidades para cada etapa de ensino. Todos os bens e serviços foram estimados por aluno, já o custo na administração do sistema de ensino foi estipulado como 5\% do Custo Aluno-Qualidade inicial.

Em relação aos insumos relacionados aos trabalhadores e as trabalhadoras em educação, evidencia-se a preocupação com "as condições de trabalho, os salários, o plano de carreira, a jornada de trabalho e a formação inicial e continuada dos trabalhadores e das trabalhadoras em educação".

A remuneração dos profissionais da educação possui o maior impacto no financiamento e consequentemente no cálculo do indicador de qualidade. Como o estudo do CAQi foi apresentado em 2007, antes da aprovação da lei do piso salarial profissional nacional, os pesquisadores utilizaram como referência o Acordo Nacional de Valorização do Magistério da Educação Básica, assinado em setembro de 1994, pelo governo Itamar Franco. O documento assegurava um salário de $\mathrm{R} \$ 300,00$ por mês, para uma jornada de 40 horas para professores com formação de nível médio (normal), ao corrigir os valores para setembro de 2005, encontra-se o valor atualizado de $\mathrm{R} \$ 1.000,00$ por mês.

O salário dos demais trabalhadores utilizou como referência o salário do professor, para cada função ou formação ocorre alguma variação. Aos docentes com ensino superior 
completo introduziu-se um adicional de 50\%, aos cargos de direção teriam um adicional 30\%, para funções de coordenação pedagógica de $20 \%$ e $30 \%$ para profissionais que lecionassem na zona rural. Aos trabalhadores que atuassem na escola com formação em nível médio o salário seria semelhante ao piso do professor e aos profissionais com ensino fundamental o salário corresponderia a 70\% (Tabela 13). Salienta-se ainda a destinação de recursos para formação continuada.

Os cálculos ainda estimaram os salários médios e em final de carreira, conforme a Resolução CNE 3/1997 que prevê uma razão de duas vezes entre o salário final e inicial. A matriz também consolidou o percentual da hora-atividade para planejamento e avaliação expressos na mesma resolução, equivalente a $20 \%$ da jornada total. Os encargos patronais com saúde e previdência foram estimados em $20 \%$ dos custos de pessoal e para cômputo das férias e do $13^{\circ}$ salário, multiplicou-se o salário mensal por $13,33 \%$ para se chegar ao valor anual.

Tabela 13 - Plano Referencial de Cargos e Salários do CAQi

\begin{tabular}{lcrrr} 
& Jornada & \multicolumn{3}{c}{ Salário (em real) } \\
\cline { 3 - 6 } \multicolumn{1}{c}{ Cargo/Função } & $(\mathrm{em}$ & & & \\
& horas) & Inicial & Médio & Final \\
\hline Professor nível médio (normal) & 30 & 750 & 1125 & 1500 \\
& 40 & 1000 & 1500 & 2000 \\
Adicional rural (+ 30\%) & 30 & 975 & 1463 & 1950 \\
& 40 & 1300 & 1950 & 2600 \\
Professor nível superior & 30 & 1125 & 1688 & 2250 \\
& 40 & 1500 & 2250 & 3000 \\
Adicional rural (+ 30\%) & 30 & 1463 & 2194 & 2925 \\
& 40 & 1950 & 2925 & 3900 \\
Coordenador (+ 20\%) & 40 & 1800 & 2700 & 3600 \\
Diretor (+ 30\%) & 40 & 1950 & 2925 & 3900 \\
Técnico com formação em nível médio & 40 & 1000 & 1500 & 2000 \\
Trabalhador com formação em nível fundamental & 40 & 700 & 1050 & 1400 \\
Bibliotecário (nível superior) & 40 & 1500 & 2250 & 3000 \\
Auxiliar de biblioteconomia (nível médio) & 40 & 1000 & 1500 & 2000 \\
\hline
\end{tabular}

Fonte: CARREIRA, D. e PINTO, J.M.R., 2007.

Obs. Os valores correspondem aos salários estabelecidos em julho de 2005.

Os insumos relacionados à gestão democrática se assemelham ao exposto em relação aos recortes de equidade e às dimensões, pois possuem pouco efeito prático. O objetivo é fomentar uma cultura de participação da comunidade escolar, que propicie práticas democráticas como a eleição de dirigentes escolares e a realização de avaliações na escola 
pelos trabalhadores e trabalhadoras em educação, em conjunto com a comunidade escolar, mas não há valores para mensurar os custos de tais ações.

Por fim, os insumos relacionados ao acesso e a permanência são aqueles atinentes aos meios para garantir a permanência dos alunos na escola, por meio de programas de transporte escolar, alimentação e material de didático. Porém, os custos com programas de transporte escolar são calculados exclusivamente para escolas do campo.

\subsubsection{Peso dos insumos do CAQi por etapa de ensino}

A tabela 8 detalha a participação dos insumos por etapa de ensino na zona urbana, os percentuais correspondem ao índice do ano de 2005. O percentual estimado com pessoal é de, no mínimo, 70\%, incluindo despesas com docentes, gestão escolar (cargos de direção, secretaria, manutenção e infraestrutura, coordenador pedagógico e auxiliar de biblioteconomia), administração e supervisão e encargos sociais.

Os custos com creches apresentam descolamento das demais etapas de ensino, registrando o maior gasto com pessoal $(76,7 \%)$ e consequentemente, o menor valor com bens e serviços. O resultado é coerente com a metodologia, à definição de que as creches teriam uma carga horária diária de 10 horas só pode ser mantida com a ampliação das despesas com pessoal docente, enquanto os demais custos apresentam crescimento mais residual.

Tabela 14 - Participação dos Insumos por Etapa de Ensino na formação CAQi

\begin{tabular}{|c|c|c|c|c|c|}
\hline \multirow[b]{2}{*}{ Insumos } & \multicolumn{5}{|c|}{ CAQi } \\
\hline & Creches & Pré-escola & $\begin{array}{c}\text { Ensino } \\
\text { Fundamental } \\
\text { Séries Iniciais }\end{array}$ & $\begin{array}{c}\text { Ensino } \\
\text { Fundamental } \\
\text { Séries Finais }\end{array}$ & $\begin{array}{l}\text { Ensino } \\
\text { Médio }\end{array}$ \\
\hline Pessoal & $76,7 \%$ & $71,3 \%$ & $70,0 \%$ & $71,6 \%$ & $72,9 \%$ \\
\hline Docente & $43,4 \%$ & $35,3 \%$ & $38,9 \%$ & $39,3 \%$ & $38,2 \%$ \\
\hline Gestão Escolar & $15,7 \%$ & $19,3 \%$ & $14,4 \%$ & $15,8 \%$ & $18,1 \%$ \\
\hline Administração e supervisão - Sec. Educação & $5,0 \%$ & $5,0 \%$ & $5,0 \%$ & $5,0 \%$ & $5,0 \%$ \\
\hline Encargos sociais & $12,6 \%$ & $11,7 \%$ & $11,7 \%$ & $11,6 \%$ & $11,7 \%$ \\
\hline Bens e serviços & $23,3 \%$ & $28,7 \%$ & $30,0 \%$ & $28,4 \%$ & $27,1 \%$ \\
\hline Água/luz/telefone & $2,9 \%$ & $2,7 \%$ & $2,7 \%$ & $2,1 \%$ & $2,1 \%$ \\
\hline Material de limpeza & $0,9 \%$ & $0,7 \%$ & $0,7 \%$ & $0,7 \%$ & $0,7 \%$ \\
\hline Materiais pedagógicos e brinquedos por criança & $2,4 \%$ & $5,6 \%$ & $5,6 \%$ & $5,9 \%$ & $5,7 \%$ \\
\hline Projetos de ações pedagógicas por criança & $2,4 \%$ & $5,6 \%$ & $5,6 \%$ & $5,9 \%$ & $5,7 \%$ \\
\hline Material de escritório & $0,4 \%$ & $0,7 \%$ & $0,7 \%$ & $0,7 \%$ & $0,7 \%$ \\
\hline Conservação predial & $1,7 \%$ & $1,6 \%$ & $1,3 \%$ & $2,5 \%$ & $2,1 \%$ \\
\hline Manutenção e reposição de equipamento & $1,2 \%$ & $2,7 \%$ & $2,7 \%$ & $2,8 \%$ & $2,7 \%$ \\
\hline Alimentação Escolar & $8,6 \%$ & $7,3 \%$ & $8,8 \%$ & $6,3 \%$ & $5,8 \%$ \\
\hline Formação profissional & $2,7 \%$ & $1,9 \%$ & $2,0 \%$ & $1,5 \%$ & $1,5 \%$ \\
\hline
\end{tabular}

Entre os bens e serviços se destaca a alimentação escolar que chega a ocupar $8,8 \%$ das despesas com ensino fundamental nas séries iniciais, valor próximo ao registrado nas creches $(8,6 \%)$, o menor percentual é registrado no ensino médio. Na sequência identifica-se a 
importância de projetos de ações pedagógicas e materiais pedagógicos e brinquedos, ambos com uma participação de 5,9\% nas séries finais do ensino fundamental, nas creches o percentual é não corresponde à metade dos gastos das demais etapas de ensino. Conservação predial e manutenção e reposição de equipamento acumulam percentuais que variam de $2,9 \%$ a 5,3\%, e a despesas com serviços básicos de água, luz e telefone variam de 2,1\% a 2,9\%. Por fim, destaca-se o peso da formação continuada, de 2,7\% nas creches e de 1,5\% nas séries finais do ensino fundamental e ensino médio.

A publicação de Carreira e Pinto (2007) foi um dos principais instrumentos que subsidiou as definições do Conselho Nacional de Educação sobre os padrões mínimos de qualidade. O Parecer do CNE/CEB n 8 de 05 de maio de 2010, estabeleceu normas para aplicação do inciso IX do artigo $4^{\circ}$ da Lei $n^{\circ}$ 9.394/96 (LDB), que trata dos padrões mínimos de qualidade de ensino para a Educação Básica, neste o CAQi foi inserido como o modelo de regulamentação dos padrões mínimos de qualidade do ensino.

Do estudo de Carreira e Pinto ao parecer do Conselho Nacional de Educação ocorreram poucas modificações, entre elas destaca-se a ampliação do número de alunos por turma nas creches, o aumento de número de professores em determinadas etapas, bem como o aumento do percentual de docentes com ensino superior completo, estas modificações impactaram no valor per capita por aluno.

Na primeira pesquisa empregou-se o PIB per capitar como parâmetro para se avaliar o CAQi, no parecer do CNE os percentuais se referenciavam ao PIB per capita de 2008, prática que se consolidou. Assim, os valores atualizados CAQi se referem à variação do PIB per capita. Em resumo, o CAQi definiu uma cesta de bens e serviços para cada etapa de ensino, mas os atualiza, anualmente, conforme a variação do PIB per capita. Deste modo a matriz complexa para definição do custo de uma educação de qualidade é atualizada por uma das medidas econômicas mais genéricas, que não mensura nem mesmo realidades estruturais como a desigualdade brasileira. 
Tabela 15 - Participação do CAQi no PIB per capita segundo a etapa de ensino

\begin{tabular}{l|c|c|c}
\hline \multirow{2}{*}{ Etapas de Ensino } & \multicolumn{3}{c}{ PIB per capita } \\
\cline { 2 - 4 } & $\mathbf{2 0 0 5}$ & $\mathbf{2 0 0 8}$ & $\mathbf{2 0 1 3}$ \\
\hline Creche & $39,3 \%$ & $39,0 \%$ & $39,0 \%$ \\
Pré-escola & $17,0 \%$ & $15,1 \%$ & $15,1 \%$ \\
Ensino Fundamental Séries Iniciais (Urbano) & $16,4 \%$ & $14,4 \%$ & $14,4 \%$ \\
Ensino Fundamental Séries Finais (Urbano) & $16,1 \%$ & $14,1 \%$ & $14,1 \%$ \\
Ensino Médio & $16,6 \%$ & $14,5 \%$ & $14,5 \%$ \\
Ensino Fundamental Séries Iniciais (Rural) & $22,7 \%$ & $23,8 \%$ & $23,8 \%$ \\
Ensino Fundamental Séries Finais (Rural) & $22,0 \%$ & $18,2 \%$ & $18,2 \%$ \\
\hline
\end{tabular}

Fonte: Custo Aluno-Qualidade inicial: rumo à educação pública de qualidade, Parecer CEB n 8/2010 e Portal Custo Aluno-Qualidade, link: http//www_custoalunoqualidade_org.br

Na sequência se analisará a cesta de bens e serviços do CAQi comparativamente ao efetuado na rede municipal da cidade de São Paulo. O valor aluno do Fundeb no estado de São Paulo é sempre evocado como um valor de referência para implementação do CAQi. O município de São Paulo é bem posicionado no estado quando se trata do financiamento da educação, pois possui um contingente populacional em idade escolar que foi responsável por gerar um saldo positivo com o Fundeb de R\$ 1,4 bilhão em 2015 e a arrecadação dos dois principais impostos próprios (IPTU e ISS), vinculados ao ensino e disponíveis para aplicação na rede de ensino municipal, não são destinados ao Fundeb, conforme o quadro 1, mas são extremamente significativos em termos de volume de recursos, a arrecadação em 2015 destes impostos foi de R\$ 20 bilhões.

\subsection{Determinantes de custos na rede municipal de São Paulo}

Os três pontos que justificam a comparação do CAQi com o município de São Paulo tratam das possibilidades de acumulação de recursos, seja pela intensa atividade econômica no estado e na cidade, quanto pelas atuais regras de vinculação de receitas com manutenção e desenvolvimento do ensino e do Fundeb que inserem o município em uma posição privilegiada. Entretanto, a comparação será em relação à despesa, para tanto se inicia com um breve histórico do processo legislativo sobre a definição das despesas educacionais, apresenta na sequência a metodologia de custos adotada e, logo depois, a análise para aferição dos gastos educacionais no município.

\subsubsection{Legislação municipal sobre manutenção e desenvolvimento do ensino}

A vinculação de recursos à educação no município de São Paulo não se limita a determinação constitucional de aplicação de $25 \%$ da receita resultante de impostos e 
transferências na manutenção e desenvolvimento do ensino. A Lei Orgânica do Munícipio de São Paulo prevê a destinação de $31 \%$ para manutenção e desenvolvimento do ensino fundamental, da educação infantil e inclusiva.

O termo "inclusiva" foi incluído pela Emenda à Lei Orgânica n ${ }^{\circ} 24$ de 22 de dezembro de 2001, a redação anterior vinculava 30\% dos recursos exclusivamente à educação infantil e ao ensino fundamental. A promulgação da LDB ao final de 1996 com a definição do que poderia ser computado, ou não, como manutenção e desenvolvimento do ensino dificultava a execução do plano de governo da então prefeita Marta Suplicy que tinha como um dos principais pontos a construção dos Centros de Educação Unificados (CEUs). O entendimento era de que as edificações escolares integradas a equipamentos de cultura e esporte não eram contempladas pelo conceito de manutenção e desenvolvimento do ensino, por isso, o governo do Partido dos Trabalhadores apresentou emenda à Lei Orgânica ampliando tanto o percentual de aplicação como o conceito para apuração dos recursos na educação.

$\mathrm{Na}$ oportunidade incluíram também em manutenção e desenvolvimento do ensino os programas de transporte escolar, uma vez que, a LDB já havia permitido tal contabilização, até então os valores dispendidos com transporte escolar não compunham o índice de aplicação. O Projeto de Emenda da Orgânica tramitou junto com o Projeto de Lei $n^{o}$ $548 / 2001$, que incluía o pagamento de aposentados dentro dos $25 \%$ e regulamentava as despesas que seriam permitidas na faixa de $25 \%$ a $31 \%$.

No entanto, a nova definição não foi consenso nem mesmo na base aliada da prefeita, os vereadores Carlos Gianazzi (PT) e Cláudio Fonseca (PCdoB) votaram contra a alteração, o revés quase impediu a aprovação da medida que contou com número de votos mínimos na primeira votação, para ambos a ampliação do conceito implicaria na utilização de recursos da educação para outros fins. O episódio custou caro aos parlamentares, Gianazzi ${ }^{18}$ foi expulso do Partido dos Trabalhadores e Cláudio Fonseca ${ }^{19}$ teve a legenda cassada no final do mandato pelo partido, impossibilitando a candidatura para reeleição.

Após este embate a única alteração ocorreu por meio da Lei $\mathrm{n}^{\circ} 15.963$, de 15 de janeiro de 2014, a qual instituiu que as despesas com pagamento de aposentadorias passariam progressivamente a serem contabilizadas na faixa de $25 \%$ a $31 \%$, ou seja, não seriam

\footnotetext{
${ }^{18}$ FOLHA DE SÃO PAULO. PT expulsa vereador que votou contra Marta. Folha de São Paulo, Reportagem Local, Cotidiano, 17 abr. 2002. Disponível em: < https://www1.folha.uol.com.br/fsp/cotidian/ff1704200203.htm> Acesso em 10 dez. 2018.

${ }^{19}$ FOLHA DE SÃO PAULO. Vereador do PC do B que votou contra Marta perde apoio do próprio partido. Folha de São Paulo, Cotidiano, 24 abr. 2001. Disponível em: < https://www1.folha.uol.com.br/fsp/cotidian/ff2404200111.htm > Acesso em 10 dez. 2018.
} 
computadas no limite constitucional dos $25 \%$. Além dessa medida também foi incluído inciso que prevê a contabilização das despesas com proteção escolar, realizadas pela Secretaria Municipal de Segurança Pública, no limite de 31\%.

A retirada progressiva dos inativos do percentual dos $25 \%$ contou com participação decisiva dos Conselheiros do Tribunal de Contas do Município, o órgão havia constituído grupo de trabalho para avaliar a exclusão das despesas com inativos da educação do cômputo dos gastos com a manutenção e desenvolvimento do ensino municipal, em 26 de novembro de 2013 os conselheiros realizaram o $3^{\circ}$ julgamento da matéria, em grau exaustivo e terminativo pela retirada dos inativos do computo dos $25 \%$. Para cumprir a sentença o Executivo apresentou substitutivo em 17 de dezembro de 2013 ao Projeto de $n^{\circ}$ 646/2011, as comissões competentes foram favoráveis ao substitutivo e o projeto foi aprovado no plenário no mesmo dia. Na primeira ocasião o tema gerou tamanha polêmica que dois parlamentares foram expulsos dos seus respectivos partidos, na segunda, não foi registrado nem mesmo cinco minutos de discussão sobre a matéria.

A tabela 10 apresenta o total apropriado das despesas com pagamento de inativos, nos $25 \%$ e na faixa de $25 \%$ a $31 \%$, nota-se que em 2015 ainda era permitido que $60 \%$ deste gasto fosse contabilizado na parcela definida constitucionalmente, e a diferença dentro do limite municipal de $31 \%$.

\begin{tabular}{ccc} 
Tabela 16 & $\begin{array}{c}\text { Regra de transição para contabilização } \\
\text { das despesas com inativos, Prefeitura } \\
\text { Municipal de São Paulo, 2015-2017 }\end{array}$ \\
\hline \multirow{3}{*}{ Ano } & $\begin{array}{c}\text { Percentual } \\
\text { apropriado } \\
\text { nos 25\% }\end{array}$ & $\begin{array}{c}\text { Percentual } \\
\text { apropriado na faixa } \\
\text { de 25\% a 31\% }\end{array}$ \\
\hline 2014 & $80 \%$ & $20 \%$ \\
2015 & $60 \%$ & $40 \%$ \\
2016 & $40 \%$ & $60 \%$ \\
2017 & $20 \%$ & $80 \%$ \\
2018 & $0 \%$ & $100 \%$ \\
\hline
\end{tabular}

Fonte: Lei ${ }^{\circ} 15.963$, de 15 de janeiro de 2014

$\mathrm{Na}$ sequência para fins de comparação com a matriz do CAQ será analisada a execução orçamentária da Secretaria Municipal de Educação do município de São Paulo referente ao exercício de 2015. Para tanto são necessárias duas observações: a primeira é que parte dos gastos com manutenção e desenvolvimento do ensino não são realizados pela Secretaria Municipal de Educação, como o pagamento de inativos, despesas com subsídio da tarifa do transporte municipal e despesas com proteção escolar, dentre outras. A segunda que 
nem todas as despesas da Secretaria da Educação são única e exclusivamente aplicadas ao ensino.

\subsubsection{Metodologia para análise de custos na cidade de São Paulo}

O objetivo deste capítulo é desenvolver uma análise de custos referente aos gastos com manutenção e desenvolvimento de ensino da rede municipal de São Paulo que permita a comparação com os parâmetros do CAQi. Para tanto, na seção 6.1 foi apresentado as decisões para composição do indicador, nesta serão descritas as escolhas metodológicas realizadas para definição dos custos com MDE na rede municipal de São Paulo.

O Artigo 99 da Lei Federal $n^{\circ} 4.320 / 1964$ já impunha que os serviços públicos deveriam manter contabilidade especial para determinação de custos (MAUSS; SOUZA, 2008). E em 2000, a Lei de Responsabilidade Fiscal (LRF), definiu em seu art. $4^{\circ}$, inciso I, alínea e, que na Lei de Diretrizes Orçamentárias (LDO), aprovada anualmente, deveria conter "normas relativas ao controle de custos e à avaliação de resultados dos programas financiados com recursos dos orçamentos" (MACHADO, 2005 apud KHAIR, 2000). Entretanto, tais normas não seriam cumpridas pelo poder público (MAUSS; SOUZA, 2008 apud SILVA, 1999). Segundo Machado e Holanda (2010) salvo algumas exceções, a administração pública, em todos os poderes e entes, não utilizava sistema de custos até 2010, ano em que encontrou em operação o Sistema de Informação de Custos do Governo Federal (SIC). Contudo, na Prefeitura Municipal de São Paulo ainda não se opera uma contabilidade de custos, seja ela aplicada linearmente para todos os órgãos ou específica para manutenção e desenvolvimento do ensino.

Tendo em vista a ausência de diagnóstico da administração municipal este estudo realizou uma análise de custos para manutenção e desenvolvimento de ensino. Para solicitar dados e informações necessárias para compor este estudo foi necessário definir a metodologia de apuração dos custos. Em primeiro lugar, é preciso indicar os conceitos de custos. Machado (2005) cita a terminologia de custos apresentada por Eliseu Martins (1996), que destaca os seguintes conceitos:

Gasto: "Sacrifício financeiro com que a entidade arca para a obtenção de um produto ou serviço qualquer, sacrifício esse representado por entrega ou promessa de entrega de ativos";

Investimentos: "gasto ativado em função de sua vida útil ou de benefícios atribuíveis a futuros períodos";

Custo: "gasto relativo a bem ou serviço utilizado na produção de outros bens ou serviços"; 
Despesa: "bem ou serviço consumido direta ou indiretamente para obtenção de receitas";

Desembolso: "pagamento resultante da aquisição do bem ou serviço" (MACHADO; HOLANDA, 2010 apud MARTINS, 2003).

$\mathrm{Na}$ contabilidade empresarial o gasto inicial pode ser convertido em investimento, custo ou despesa. O investimento posteriormente se transformaria em custo, e os custos em última instância em despesas (Quadro 1). A diferenciação entre investimento e custo está na vida útil do bem, enquanto o primeiro tem o seu fator de utilização prologando o segundo é consumido no processo de produção no curto prazo. Já custo e despesa se diferenciação pela vinculação à processos, o custo é a atribuição de um gasto, seja ele bem ou serviço, na produção de um outro bem ou serviço, enquanto a despesa, pode estar ou não vinculada com a produção de um bem ou serviço (Machado, 2005). O exemplo mais comum de despesa que não é atribuída inicialmente a custo é a contratação de serviços de publicidade, que não interferem no processo de elaboração do bem ou serviço.

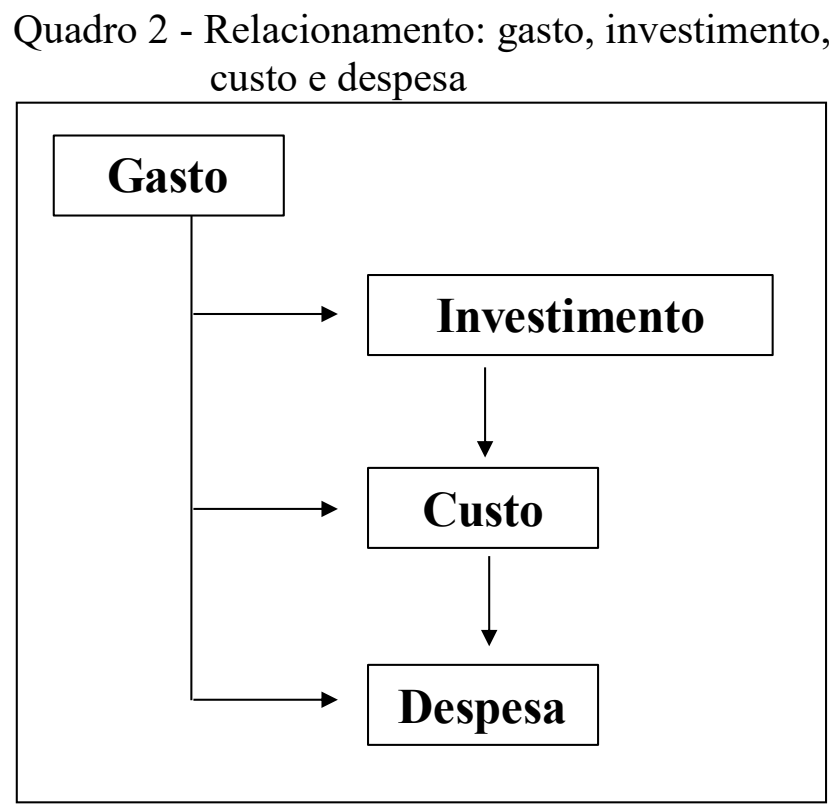

Fonte: MACHADO (2005)

As fases de despesa do sistema orçamentário apresentam correspondência entre os conceitos de custos. A fixação da despesa no orçamento seria corresponde ao custo-padrão, com valores estimados para realização bens e serviços, as despesas liquidadas equivaleriam ao gasto da contabilidade empresarial, ou seja, o compromisso de pagamento pela entrega de um bem e serviço, e o desembolso é representado pela fase de pagamento (MACHADO; HOLANDA; 2010). A única fase de despesa do setor público que não guarda correspondência com o privado é o empenho, que "consiste na reserva de dotação orçamentária para um fim em específico" (BRASIL, 2018). 
Quadro 3 - Contabilidade governamental x contabilidade de custos: correspondência terminológica

\begin{tabular}{|ll|}
\hline Contabilidade governamental & Contabilidade de custos empresarial \\
\hline Fixaçāo & Padrão \\
Empenho & Nāo ê tradicionalmente usado \\
Liquidaç̄o & Gasto (realizado) \\
Pagamento & Desembolso \\
\hline
\end{tabular}

Fonte: MACHADO; HOLANDA, 2010 apud MACHADO, 2002)

Machado (2005) ressalta que a diferenciação entre custo e despesa é irrelevante no setor público, uma vez que está diferenciação é utilizada no setor privado para "avaliação de estoque de produtos que serão vendidos no período seguinte". Entretanto, este estudo classificará os valores liquidados pela Secretaria Municipal de Educação do município de São Paulo no exercício de 2015, segundo as três categorias. Os gastos identificados como manutenção e desenvolvimento do ensino serão contabilizados como custo ou investimento, enquanto os demais serão considerados despesas. Mauss e Souza (2008) identificam que além da integração dos sistemas é requisito para uma análise apurada o registro de informações sobre a execução física, com o quantitativo correspondente para cada programa, projeto e ação. Nestes termos uma apuração de custos depende da estruturação de procedimentos administrativos para o registro e a conexão dos quatro sistemas com o controle da execução física. Contudo para a apuração de custos do setor público por meio de estudos acadêmicos existe um único caminho, alinhar informações gerenciais de outras fontes a execução orçamentária.

A obtenção de informações e dados para elaboração da análise de custos esbarrou em três dificuldades: a primeira se referia a ausência de direcionador no orçamento e na execução orçamentária capazes de identificar as gastos com manutenção e desenvolvimento do ensino, sem esta informação caberia, exclusivamente, a reclassificação das despesas da Secretaria Municipal de Educação, considerando que esta teria a totalidade dos gastos com MDE. O segundo problema estava na ausência de detalhamento da execução orçamentária das despesas de pessoal, não havia nenhuma categoria que indicasse a etapa de ensino em que os gastos com pessoal foram liquidados, nenhuma despesa de pessoal estava classificada nas subfunções educação infantil e ensino fundamental, e os projetos e programas não auxiliavam neste processo. A terceira dificuldade é uma extensão da segunda, pois as despesas com bens e serviços também possuíam uma classificação precária por etapas de ensino, por meio das subfunções orçamentárias. 
Neste sentido, foram empregadas duas estratégias. A primeira era solicitar a Secretaria Municipal da Fazenda a execução orçamentária detalhada (quadro detalhado de despesas) correspondente ao Relatório Resumido de Execução Orçamentária (RREO) das receitas e despesas com manutenção e desenvolvimento do ensino, uma vez que o documento resumia os gastos correspondentes à MDE por etapa de ensino. A outra era solicitar a Secretaria Municipal de Gestão a base de dados da folha de pagamento dos servidores da Secretaria Municipal de Educação segundo o local de trabalho referente ao mês de setembro de 2015. A primeira base de dados já solucionaria as dificuldades apresentadas acima, a segunda demandaria o cruzamento dos dados de servidores da educação com os microdados do Censo Escolar para identificar as matrículas correspondentes para cada etapa de ensino.

O pedido de informação à Secretaria Municipal de Gestão foi respondido dentro do prazo previsto pela lei de acesso à informação. O segundo realizado à Secretaria Municipal da Fazenda não encaminhado, o órgão justificou que não seriam "atendidos pedidos de acesso à informação que: 'exijam trabalhos adicionais de análise, interpretação ou consolidação de dados e informações, ou serviço de produção ou tratamento de dados que não seja de competência do órgão ou entidade"”, trecho correspondente ao inciso III $\S 1^{\circ}$ do artigo 16 do Decreto Municipal $\mathrm{n}^{\mathrm{o}}$ 53.623/2012 $2^{20}$.

Sobre a competência, o inciso II do artigo 19 do Decreto $\mathrm{N}^{\mathrm{o}} 58.030$, de 12 de dezembro de 2017, que dispõe sobre a reorganização da Secretaria Municipal da Fazenda, assegura que é competência da Divisão de Informações Gerenciais Contábeis da Secretaria Municipal da Fazenda a elaboração dos demonstrativos exigidos pela Lei de Responsabilidade Fiscal. Em relação aos dados de acesso público, não há na execução orçamentária nenhum dispositivo que permita realizar tal mensuração. Entre a execução orçamentária e o demonstrativo de receitas e despesas com manutenção de ensino há uma lacuna que precisaria ser respondida pelo Executivo.

O procedimento administrativo que sistematiza a execução orçamentária para fins de prestação de contas é realizado pelos técnicos da Secretaria Municipal da Fazenda, a solicitação era apenas de publicidade dos critérios adotados, por esta razão foi apresentado recurso à resposta do órgão. Contudo, a resposta ao recurso apresentado foi ainda mais taxativa,

conforme estabelece a redação do artigo 16 do Decreto $\mathrm{n}^{\mathrm{o}}$ 53.623/2012, a liberação de informações no âmbito dos pedidos de informação passa a prejudicar o interesse público geral quando exige 'trabalhos adicionais de

\footnotetext{
${ }^{20}$ A solicitação foi respondida pelo chefe de gabinete da Secretaria Municipal da Fazenda, Arlinton Nakazawa.
} 
análise, interpretação ou consolidação de dados e informações, ou serviço de produção ou tratamento de dados ${ }^{21}$.

A recusa em apresentar os dados detalhados da execução orçamentária referente à manutenção e desenvolvimento do ensino não é exclusividade desta pesquisa, no relatório de auditoria do Tribunal de Contas do Município de São Paulo referente ao exercício de 2017 encontra-se a seguinte reiteração:

A SF deve elaborar demonstrativo com memória de cálculo dos rateios e
índices de apropriação parcial de despesas com educação, com detalhamento
do código das dotações completas envolvidas, critérios/parâmetros
utilizados, além das justificativas legais, que respaldem os números
apresentados no Demonstrativo de Receitas e Despesas com Manutenção e
Desenvolvimento do Ensino (TRIBUNAL DE CONTAS DO MUNICÍPIO
DE SÃO PAULO, 2017, p. 28).

Até este ponto da pesquisa estava disponível somente a base de dados extraída do Sistema de Orçamento e Finanças (SOF), referente ao quadro de demonstrativo de despesa da Secretaria Municipal de Educação do exercício de 2015. Tendo em vista que não foi superada a dificuldade inicial de obtenção da execução orçamentária por etapa de ensino com MDE, e tendo ciência que parte dos recursos eram executados em outros órgãos, optou-se pela utilização do parecer do Tribunal de Contas em relação às despesas liquidadas com manutenção e desenvolvimento do ensino, com este era possível identificar as gastos com MDE que ocorreram fora da Secretaria Municipal de Educação. Para todos as tabelas e análises foi utilizada a despesa na fase de liquidação.

Explicitada as condições básicas para o estudo de custos, resta saber qual a forma de acumulação de custos e o método de apropriação. A forma de acumulação neste caso deve ser suficiente para propiciar uma análise comparativa com o CAQi. Além das etapas de ensino, uma série de categorias serão indispensáveis para aferição de custo.

A base de dados da execução orçamentária possui 60 variáveis e 49.255 registros. As principais variáveis de conteúdo são: a classificação institucional da despesa (órgão e unidade administrativa), funcional (função e subfunção), programática (programa e projeto) econômica (categoria, grupo, elemento de despesa e modalidade de aplicação), juntamente com item de despesa, subelemento da despesa, observações de empenho, cnpj e razão social do credor, modalidade de licitação e fonte de recursos. As variáveis de conteúdo são: valor do empenho, valor do cancelamento de empenho, valor liquidado, valor pago, valor a liquidar e valor a pagar.

\footnotetext{
${ }^{21}$ Resposta apresentada pelo Sr. Luis Felipe Vidal Arellano, Secretário Municipal da Fazenda/Substituto.
} 
Além das variáveis da base de dados foram sintetizadas outras 7 para análise de custos: econômica, finalidade, rede, insumos detalhados, insumos, tipo de MDE e etapas de ensino. A variável econômica reflete parcialmente a classificação econômica orçamentária, esta possui três categorias: pessoal (inclui todas as despesas de pessoal da classificação econômica e contratos de mão de obra, em especial, estagiários), bens e serviços (inclui tanto o grupo de despesa “outras despesas correntes" como "investimentos) e contratos de terceirização de atividade fim (contratos em que a administração integral da escola incumbe ao setor privado), a associação dos gastos ao custo é realizada por atribuição direta.

A variável finalidade estrutura a análise ao dividir os gastos em: educacional, assistencial, cultural e esportiva. Para os gastos com manutenção e desenvolvimento do ensino são consideradas apenas os custos da categoria educacional, também por atribuição direta dos gastos. As variáveis rede e etapas de ensino são as únicas em que o custo é realizado por absorção, a variável rede possui duas categorias: direta e conveniada, além dos contratos de terceirização das atividade fim da variável econômica, classifica-se como conveniada o percentual de servidores que se dedicam a regulação do sistema de conveniamento e os valores liquidados com programas de permanência e acesso nessas unidades.

Insumos detalhados é a variável mais específica, possui 58 classificações distintas e foi sistematizada por um conjunto de processos, todos por custeio direto. Para esta consolidação realizou-se o cruzamento das seguintes variáveis: item de despesa, subelemento, observações de empenho, projeto, subfunção, razão social, finalidade e os insumos detalhados pré-classificados. A base de categorias desta variável se origina dos insumos do CAQi, mas no início do trabalho ficou evidente ser essencial a criação de novas nomenclaturas, por um lado havia o esforço de manter a coerência dos registros orçamentários e de outro as pretensões da pesquisa de comparabilidade. Ao final a decisão foi manter a máxima coerência com os registros orçamentários e criar uma nova variável para agrupar os insumos detalhados. A memória de cálculo de cada categoria encontra-se no anexo B. O título da nova variável é insumos, que é composta exclusivamente dos insumos detalhados.

A variável tipo MDE possui duas categorias: manutenção e desenvolvimento. Na categoria desenvolvimento estão investimentos com aquisição e construção de edificações e infraestrutura para tecnologia de informação, em manutenção estão todos os demais insumos.

Por fim, como antecipado a classificação mais relevante é referente às etapas de ensino, porém os dados não facilitam este processo. A tarefa seria simples se o Executivo utilizasse a recomendação do Tribunal de Contas do Estado de São Paulo, que admite apenas 
as despesas classificadas nas subfunções ensino fundamental, educação infantil, educação de jovens e adultos e educação especial para fins da apuração dos gastos em manutenção e desenvolvimento do ensino. Na Secretaria Municipal de Educação este conjunto de subfunções não representa $20 \%$ das despesas, subfunções genéricas sem relação com a etapa e modalidade de ensino são a regra. Segundo o parecer do Tribunal de Contas do Município o Quadro 3 "evidencia que a alocação de recursos nas subfunções dentro do sistema orçamentário da Prefeitura Municipal de São Paulo (PMSP) não representa a realidade dos gastos efetivos com as respectivas modalidades de ensino."

Quadro 4 - Comparativo de gastos informados com educação infantil e ensino fundamental

\begin{tabular}{|c|c|c|c|}
\hline \multicolumn{2}{|c|}{ PMSP (Sistema SOF) } & \multicolumn{2}{c|}{ PMSP (Publicação RREO) } \\
\hline $\begin{array}{c}\text { Subfunção 365 } \\
\text { (Educaçẫo Infantil) }\end{array}$ & $\mathrm{R} \$ 2.064 .140 .266$ & $\begin{array}{c}\text { Linha 22 } \\
\text { (Educação Infantil) }\end{array}$ & $\mathrm{R} \$ 6.435 .080 .611$ \\
\hline $\begin{array}{c}\text { Subfunção 361 } \\
\text { (Ensino Fundamental) }\end{array}$ & $\mathrm{R} \$ 11.094 .850$ & $\begin{array}{c}\text { Linha 23 } \\
\text { (Ensino Fundamental) }\end{array}$ & $\mathrm{R} \$ 4.370 .241 .558$ \\
\hline
\end{tabular}

Valores empenhados exercício 2017

Fonte: Tribunal de Contas do Município de São Paulo

Como o município não divulga a forma de rateio destas despesas liquidadas por etapa de ensino a alternativa foi criar métricas para estimar os custos referentes a cada etapa de ensino. Os valores foram apropriados para dois conjuntos de dados distintos, um para as gastos de pessoal, a base de dados da folha de pagamentos dos servidores da Secretaria Municipal de Educação, e o outro, para os bens e serviços verificados no banco de dados da execução orçamentária.

Para utilização do banco de dados da folha de pagamentos duas variáveis foram sintetizadas, servidores segundo tipo de função e local de trabalho. Os tipos de função eram: docente, gestor/especialista e profissionais de apoio, enquanto local de trabalho era agrupado como atuando em escolas ou fora das escolas (Secretaria Municipal de Educação e Diretoria Regional de Ensino). O primeiro passo para classificar as despesas liquidadas de pessoal por etapa de ensino foi identificar à área de atuação dos cargos e a etapa de ensino correspondente em todos os equipamentos, por este método foi possível classificar $82,9 \%$ do gasto de pessoal. Para os demais cargos foi utilizado o percentual de representação das turmas ajustadas pela carga horária semanal de cada etapa de ensino e os valores foram apropriados conforme cada caso. Ao final o resultado da folha de pagamento de setembro era estendido para o exercício de 2015 (Tabela 17). 
Tabela 17 - Método de apropriação de custos por etapa de ensino das despesas de pessoal. Secretaria Municipal da Educação, 2015

\begin{tabular}{|c|c|c|c|}
\hline \multirow[b]{2}{*}{$\begin{array}{c}\text { Tipo de Função/ Etapa } \\
\text { de Ensino }\end{array}$} & \multirow[b]{2}{*}{ Rede de Ensino } & \multicolumn{2}{|c|}{ Local de Trabalho } \\
\hline & & Escolas & $\begin{array}{c}\text { Secretaria Municipal da } \\
\text { Educação/ Diretoria } \\
\text { Regional de Ensino }\end{array}$ \\
\hline \multicolumn{4}{|l|}{ Docente } \\
\hline \multirow{2}{*}{ Creche } & Conveniada & - & \multirow{5}{*}{$\begin{array}{l}\text { Estimativa por turma e } \\
\text { carga horária semanal2 }\end{array}$} \\
\hline & Direta & \multirow{4}{*}{$\begin{array}{l}\text { Atribuição por cargo } \\
\text { e equipamento }\end{array}$} & \\
\hline Pré-escola & Direta & & \\
\hline Ensino Fundamental ${ }^{1}$ & Direta & & \\
\hline Ensino Médio & Direta & & \\
\hline \multicolumn{4}{|l|}{ Gestor/Especialista } \\
\hline \multirow{2}{*}{ Creche } & Conveniada & - & \multirow{5}{*}{$\begin{array}{l}\text { Estimativa por turma e } \\
\text { carga horária semanal2 }\end{array}$} \\
\hline & Direta & \multirow{4}{*}{$\begin{array}{l}\text { Atribuição por cargo } \\
\text { e equipamento e } \\
\text { estimativa para } \\
\text { CEUs3 e CEMEIs4 }\end{array}$} & \\
\hline Pré-escola & Direta & & \\
\hline Ensino Fundamental $^{1}$ & Direta & & \\
\hline Ensino Médio & Direta & & \\
\hline \multicolumn{4}{|l|}{ Profissionais de Apoio } \\
\hline \multirow{2}{*}{ Creche } & Conveniada & - & \multirow{5}{*}{$\begin{array}{l}\text { Estimativa por turma e } \\
\text { carga horária semanal2 }\end{array}$} \\
\hline & Direta & \multirow{4}{*}{$\begin{array}{l}\text { Atribuição por cargo } \\
\text { e equipamento e } \\
\text { estimativa para } \\
\text { CEUs3 e CEMEIs4 }\end{array}$} & \\
\hline Pré-escola & Direta & & \\
\hline Ensino Fundamental $^{1}$ & Direta & & \\
\hline Ensino Médio & Direta & & \\
\hline
\end{tabular}

Notas: 1. Os cargos e os equipamentos não se diferenciam por ensino fundamental e médio, por isso, a separação ocorreu por estimativa de participação das turmas ajustadas pela carga horária semanal, correspondente ao ensino fundamental (99,3\%) e ensino médio (0,07\%). 2. Apropriados segundo participação das turmas ajustadas pela carga horária semanal, correspondente a $41,3 \%$ com creches conveniadas, $10,6 \%$ com creches da administração direta, $14,7 \%$ pré-escola, $32,9 \%$ ensino fundamental e $0,25 \%$ do ensino médio. 3. Os valores correspondentes aos CEUs foram distriuídos conforme a partipação da turmas ajustadas pela carga horária semanal: $29,5 \%$ creches, $26,4 \%$ pré-escola e $43,9 \%$ ensino fundamental. 4. Nos CEMEls a divisão entre creches e pré-escolas foi de $50,5 \$$ e $49,5 \%$ respectivamente.

Fonte: Secretaria Municipal de Gestão.

Elaborado pelo autor.

Para estimar os custos de bens e serviços por etapa de ensino foram selecionados os gastos de interesse da pesquisa, assim, a base de dados refletia as despesas liquidadas com finalidade exclusiva na educação, excluídos os investimentos destinados às novas unidades educacionais e os investimentos para ampliar a capacidade administrativa com infraestrutura de sistemas de informação. Para definir o peso dos insumos nas etapas de ensino geraram-se seis índices com base nas informações educacionais do Censo Escolar de 2015. Os índices possuem duas fontes primárias, matrículas e turmas. Os três primeiros índices consistem na participação relativa simples, ou seja, o peso das matrículas ou do número de turmas de uma etapa de ensino em relação total, no caso de turmas um considera todas as matrículas em 
creche e o outro somente as da rede direta. Outras duas métricas ajustam o peso das matrículas e turmas segundo a jornada semanal, e o último, computa as matrículas de alunos que utilizam o transporte escolar gratuito (Tabela 18).

Tabelas 18 - Matrículas, turmas, jornada semanal e alunos que utilizam o transporte escolar, por etapa de ensino. Rede Municipal de São Paulo, 2015

\begin{tabular}{|c|c|c|c|c|c|c|c|}
\hline \multirow{3}{*}{ Informações Educacionais } & & \multicolumn{5}{|c|}{ Etapas de Ensino } & \multirow{3}{*}{ Total } \\
\hline & & \multicolumn{2}{|c|}{ Creche } & \multirow{2}{*}{ Pré-escola } & \multirow{2}{*}{$\begin{array}{c}\text { Ensino } \\
\text { Fundamental }\end{array}$} & \multirow{2}{*}{$\begin{array}{l}\text { Ensino } \\
\text { Médio }\end{array}$} & \\
\hline & & Conveniada & Direta & & & & \\
\hline \multirow{2}{*}{ Matrículas (M1) } & $\mathrm{N}^{\mathrm{o}}$ & 204.285 & 56.500 & 198.248 & 415.410 & 3.123 & 877.566 \\
\hline & $\%$ & $23,28 \%$ & $6,44 \%$ & $22,59 \%$ & $47,34 \%$ & $0,36 \%$ & $100,00 \%$ \\
\hline \multirow{3}{*}{ Turmas } & $\mathrm{N}^{\mathrm{o}}$ & 17.842 & 4.606 & 6.366 & 14.194 & 107 & 43.115 \\
\hline & $(\mathrm{T} 1) \%$ & $41,38 \%$ & $10,68 \%$ & $14,77 \%$ & $32,92 \%$ & $0,25 \%$ & $100,00 \%$ \\
\hline & (T2) $\%$ & & $18,22 \%$ & $25,19 \%$ & $56,16 \%$ & $0,42 \%$ & $100,00 \%$ \\
\hline Número de alunos por turma & & 11,4 & 12,3 & 31,1 & 29,3 & 29,2 & \\
\hline Jornada Semanal & & 50,0 & 49,5 & 30,5 & 25,0 & 22,5 & \\
\hline \multirow{2}{*}{$\begin{array}{l}\text { Total de Horas em atividades } \\
\text { com as turmas (T3) }\end{array}$} & $\mathrm{N}^{\mathrm{o}}$ & & 227.800 & 193.910 & 354.825 & 2.410 & 778.945 \\
\hline & $\%$ & & $29,24 \%$ & $24,89 \%$ & $45,55 \%$ & $0,31 \%$ & $100,00 \%$ \\
\hline \multicolumn{2}{|c|}{$\begin{array}{l}\text { Peso das matrículas ajustadas pela } \\
\text { jornada semanal (M2) }\end{array}$} & & $14,49 \%$ & $31,31 \%$ & $53,84 \%$ & $0,36 \%$ & \\
\hline \multirow{2}{*}{$\begin{array}{l}\text { Alunos que utilizam } \\
\text { Transporte Escolar (M3) } \\
\end{array}$} & $\mathrm{N}^{\mathrm{o}}$ & 286 & 567 & 30.391 & 32.886 & 28 & 64.158 \\
\hline & $\%$ & $0,45 \%$ & $0,88 \%$ & $47,37 \%$ & $51,26 \%$ & $0,04 \%$ & $100,00 \%$ \\
\hline
\end{tabular}

Fonte: Censo Escolar 2015

Elaborado pelo autor

Portanto, os pesos atribuídos por etapa dependem do insumo, se possui alta correlação com o aluno é utilizado o número de matrículas e este é ajustado pela jornada semanal caso o aumento do tempo de permanência do aluno na escola implique na elevação dos custos, de forma semelhante esta regra se aplica com as turmas. Na tabela 19 se encontra o índice aplicado para cada insumo. 
Tabela 19 - Tabela de referência de custos por absorção segundo etapas de ensino

\begin{tabular}{lc}
\hline \multicolumn{1}{c}{ Categoria Econômica, Ins umos e Ins umos Detalhados } & Forma de \\
& $\begin{array}{c}\text { Absorção de } \\
\text { Cus tos }\end{array}$ \\
(Tabela 10) \\
\hline Pessoal & T2 \\
Outros Serviços de Terceiros & \\
Bens e Serviços & - \\
Acesso e Permanência Estudantil & M2 \\
Merenda Escolar & M3 \\
Transporte Escolar & M1 \\
Material Escolar & T3 \\
Serviços de Manutenção e Apoio & T3 \\
Serviços e Materiais de Limpeza e Conservação & T3 \\
Guarda, Vigilância Ostensiva e Segurança & T3 \\
Aquisição, Refor. e Manut. de Equipamentos & T3 \\
Serviços e Materiais de Copa e Cozinha & T3 \\
Serv. e Mat. de Apoio Adm., Téc. e Operacional & T3 \\
Locação, Ampliação e Reforma de Edificações & T3 \\
Serviços Básicos & T3 \\
Transferência Financeira & T2 \\
Tecnologia da Informação & T2 \\
Armazenagem, Logística e Locomoção & T2 \\
Ações e materiais de apoio Didático-Pedagógico & T2 \\
Formação de Recursos Humanos & T2 \\
Publicidade Institucional &
\end{tabular}

Para Nelson Machado (2005) o método de apropriação de custos mais indicado é o custeio direto no setor público, que aloca todos os custos, fixos e variáveis, diretamente a todos os objetos de custo sem qualquer tipo de rateio ou apropriação. Para o autor a adoção deste método se justifica pela dispensa de "intermináveis discussões a respeito dos custos gerais transferidos" e de que este estaria fundido tanto no sistema de planejamento orçamentário como na contabilização da execução orçamentária por meio da classificação funcional de projetos e atividades, e ainda, que tal método seria implementado com facilidade, com resultados rápidos e com baixo custo de treinamento de funcionários e gestores.

No entanto em artigo mais recente Nelson Machado demonstra que a escolha do método de custeio não é determinante para a análise de custos ao afirmar, junto com Victor Branco de Holanda, que:

A escolha do método de custeio do setor público não é tarefa fácil, na medida em que há defensores para quase todos os métodos. Além disso, no setor público, diferentemente do setor privado, não há limitação legal quanto ao uso de métodos de custeio. Neste sentido, qualquer um dos cinco métodos (custeio pleno, por absorção, por atividades, variável e custeio direto) pode ser adotado (MACHADO; HOLANDA, 2010, p. 810).

Mais uma vez é necessária a manifestação de que os estudos de custos pressupõem que gestores públicos adotariam tais métodos para mensurar os custos no setor público, no entanto, o processo de um pesquisador utilizar as informações disponíveis para mensuração de 
custos esbarra em dificuldades intransponíveis. Como já relatado a peça orçamentária não identifica quais as despesas liquidadas com manutenção e desenvolvimento do ensino, e destoante da regra legal, o planejamento orçamentário para definição de programas, projetos e atividades no Plano Plurianual (PPA), na Lei de Diretrizes Orçamentárias (LDO) e na Lei Orçamentária Anual (LOA) é raro, o orçamento público é regido na maioria das gestões por um processo incremental, em que a discussão está centrada em pequenas variações em relação ao exercício anterior. Ademais, para ampliar as possibilidades incrementais na execução orçamentária o Executivo encaminha para Câmara Municipal definições excessivamente genéricas de programas, projetos e atividades, juntamente com o pedido de autorização para amplo remanejamento de dotações da lei orçamentária.

Desta maneira, a utilização restrita de programas, projetos e ações relativas execução orçamentária do município de São Paulo é insuficiente para gerar uma análise de custos através do método de custeio direto que forneça informações suficientes para identificar o peso relativo de bens e serviços nas diferentes etapas de ensino. A discussão sobre o método de custeio feita na literatura se aplica quando se trabalha "ex ante" para montar um sistema de informação de custo. Quando se trata de uma análise "ex post" o que importa é a definição de custo, do objeto que deve ser custeado, e os dados disponíveis.

Em síntese, os gastos com finalidade educacional realizados nas etapas de ensino prioritárias do município (educação infantil e ensino fundamental) para efetivar ações em manutenção e desenvolvimento do ensino na rede gerida diretamente pela administração pública são classificados como custos, em investimento estão apenas os gastos com aquisição e construção de edificações e com infraestrutura de tecnologia de informação, os demais custos com finalidades distintas (cultural, esportiva e assistência social) de outras etapas de ensino (como ensino médio) e os custos na função educacional decorrente do pagamento de insuficiência financeira para pagamento de aposentadorias e pensões de servidores da educação, dos contratos de terceirização da atividade fim, juntamente com os gastos de pessoal e de programas de acesso e permanência estudantil associados a estes contratos, não são considerados no computo final para comparação com o CAQi. Para aferição de despesas liquidadas em custos ainda seria necessário realizar as seguintes operações: ajustar os restos a pagar, controlar a aquisição/consumo de estoques e incluir os custos de depreciação, porém não há informações disponíveis para realizar tais filtros. 
Quadro 5 - Conceito de custos aplicados à manutenção e desenvolvimento do ensino, Município de São Paulo - 2015

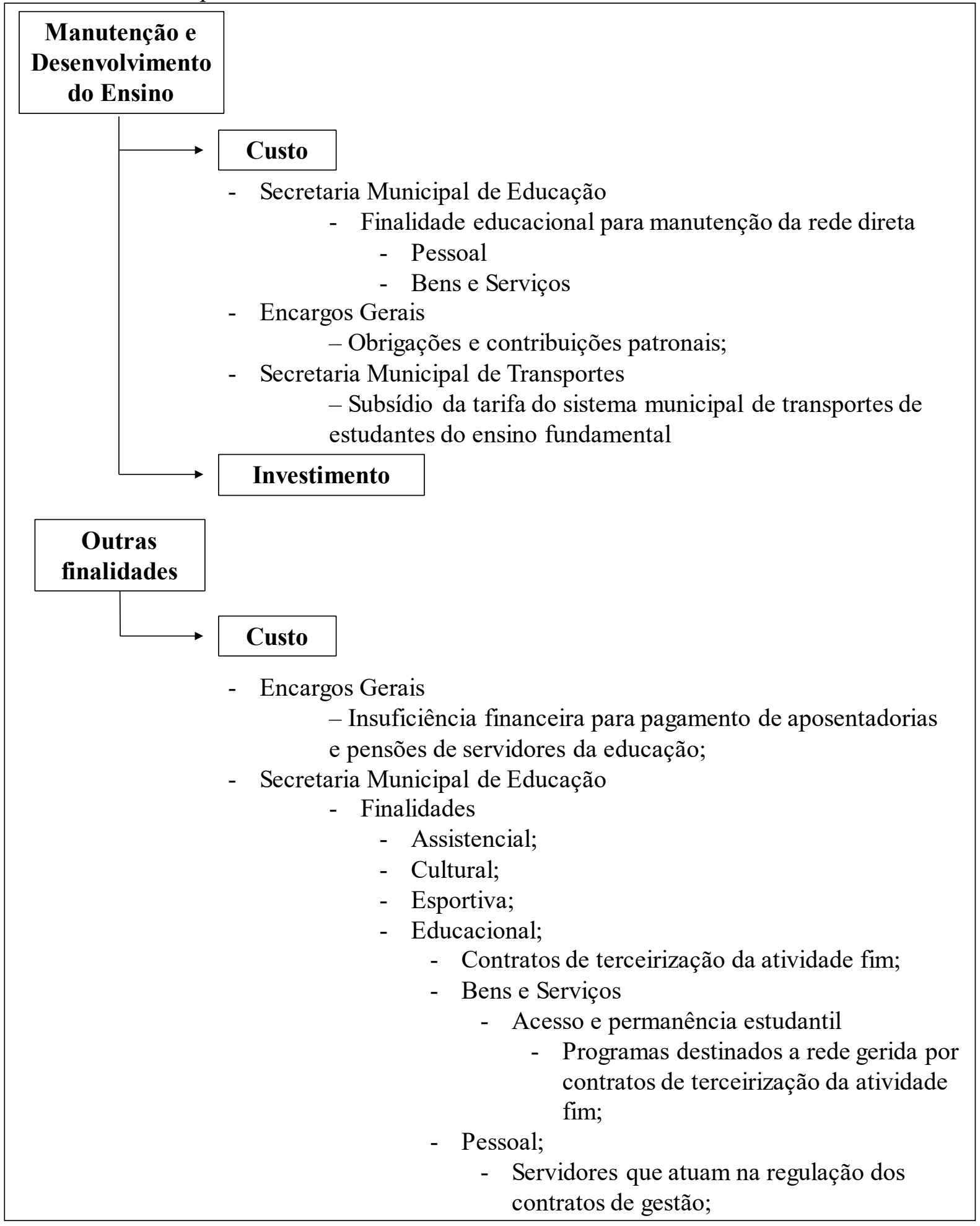

Fonte: elaboração própria. 


\subsubsection{Análise de custos com manutenção e desenvolvimento do ensino por etapa de ensino}

Inicia-se a análise pelas despesas liquidadas com manutenção e desenvolvimento do ensino, passíveis de identificação, por outros órgãos. Os gastos com a insuficiência financeira para pagamento de aposentados da Secretaria Municipal da Educação apropriada em manutenção e desenvolvimento do ensino foram de R 463 milhões em 2017, isto representa $20 \%$ dos gastos com inativos da Secretaria Municipal de Educação (SME). Para estimar os valores dispendidos se pressupôs que a participação relativa dos inativos da SME em relação ao total de aposentados se manteve constante de 2015 para 2017. Ademais, ressalta-se que em 2015 a parcela incorporada à MDE foi de $60 \%$ do total pago com a insuficiência financeira dos servidores da Secretaria Municipal de Educação. Assim, o valor apropriado em MDE referente aos aposentados foi de R\$ 1 bilhão em 2015 (Tabela 20).

Tabela 20 - Valores liquidados com aposentadorias e pensões apropriados em MDE. Prefeitura Municipal de São Paulo, 2015 - 2017

\begin{tabular}{l|c|c}
\hline \multirow{2}{*}{ Despesas } & \multicolumn{2}{c}{ Ano } \\
\cline { 2 - 3 } & $\mathbf{2 0 1 5}$ & $\mathbf{2 0 1 7}$ \\
\hline Aposentadorias e Pensões & $6.187 .984 .240,61$ & $7.994 .890 .829,81$ \\
\hline Parcela correspondente a & & \\
Secretaria Municipal da & & \\
Educação & $1.792 .132 .005,01$ & $2.315 .438 .950,00$ \\
\hline Parcela apropriada em & \\
Manutenção e & \\
Desenvolvimento do Ensino & $1.075 .279 .203,01$ & $463.087 .790,00$ \\
\hline Fonte: SOF/Secretaria Municipal da Fazenda \\
Elaborado pelo autor
\end{tabular}

Além do pagamento da insuficiência financeira para o pagamento de aposentadoria há o recolhimento da alíquota patronal referente a todos os servidores da Secretaria Municipal de Educação, de forma semelhante ao pagamento da insuficiência financeira tais gastos não são executadas pelo órgão de origem. Considerando que a participação dos servidores da educação se manteve estável entre 2015 e 2017, estima-se que a despesa liquidada com esta dotação foi de R\$ 1 bilhão (Tabela 21). 
Tabela 21 - Valores liquidados com obrigações e contribuições patronais Prefeitura Municipal de São Paulo, 2015 - 2017

\begin{tabular}{l|c|c}
\hline \multicolumn{1}{c|}{ Despesas } & \multicolumn{2}{|c}{ Ano } \\
\cline { 2 - 3 } & $\mathbf{2 0 1 5}$ & $\mathbf{2 0 1 7}$ \\
\hline $\begin{array}{l}\text { Parcela apropriada em Manutenção e } \\
\text { Desenvolvimento do Ensino }\end{array}$ & $1.030 .206 .098,93$ & $1.108 .421 .796,50$ \\
\hline & & \\
Obrigações e Contribuições Patronais & $1.698 .031 .690,04$ & $1.826 .950 .295,04$ \\
\hline
\end{tabular}

Fonte: SOF/Secretaria Municipal da Fazenda

Elaborado pelo autor

O cálculo para contabilizar o dispêndio com o subsídio da tarifa dos estudantes foi similar, primeiro se apurou o valor liquidado com o subsídio da tarifa aos estudantes do ensino fundamental (R\$ 198 milhões), depois se verificou o percentual em relação total de compensações tarifárias no ano. Assim, temos que em 2015 as despesas liquidadas como subsídio ao sistema de transporte referente aos estudantes do ensino fundamental foram de R \$ 132 milhões (Tabela 22).

Tabela 22 - Subsídio ao sistema de transporte referente aos estudantes segundo etapa de ensino.

Prefeitura Municipal de São Paulo, 2015 - 2017

\begin{tabular}{l|r|r}
\hline Etapa e Modalidade de & \multicolumn{2}{|c}{ Ano } \\
\cline { 2 - 3 } \multicolumn{1}{c|}{ Ensino } & \multicolumn{1}{|c|}{$\mathbf{2 0 1 5}$} & \multicolumn{1}{c}{$\mathbf{2 0 1 7}$} \\
\hline Ensino Fundamental & $132.098 .461,44$ & $198.655 .026,00$ \\
Ensino Médio & $163.769 .196,92$ & $246.282 .763,00$ \\
Ensino Profissionalizante & $51.685 .380,34$ & $77.726 .572,00$ \\
\hline Compensações Tarifárias & $1.928 .395 .902,70$ & $2.900 .000 .000,00$ \\
\hline Fonte: SOF/Secretaria Municipal da Fazenda & \\
Elaborado pelo autor
\end{tabular}

Expostos os gastos com MDE em outros órgãos partimos para análise do resultado da Secretaria Municipal de Educação que executou um orçamento de R\$ 9 bilhões em 2015, dessa quantia 95,8\% correspondia a gastos educacionais, R\$ 346 milhões tinham como finalidade políticas assistenciais, e na área cultura e no esporte foram aplicados R $\$ 15$ milhões e R\$ 10 milhões, respectivamente (Tabela 23). 
Tabela 23 - Valores liquidados segundo finalidade Secretaria Municipal de Educação, 2015

\begin{tabular}{l|r|r}
\hline \multirow{2}{*}{ Finalidade } & \multicolumn{1}{|c|}{ Valores Liquidados } \\
\cline { 2 - 3 } & \multicolumn{1}{|c|}{ Nominal } & \multicolumn{1}{c}{$\%$} \\
\hline Educacional & $8.632 .191 .375,59$ & $95,8 \%$ \\
Assistencial & $346.856 .310,85$ & $3,9 \%$ \\
Cultural & $15.159 .308,99$ & $0,2 \%$ \\
Esportiva & $10.856 .019,42$ & $0,1 \%$ \\
Demais gastos & $2.807 .247,44$ & $0,0 \%$ \\
\hline Total Geral & $\mathbf{9 . 0 0 7 . 8 7 0 . 2 6 2 , 2 9}$ & $\mathbf{1 0 0 , 0 \%}$ \\
\hline
\end{tabular}

Fonte: SOF/Secretaria Municipal da Fazenda

Elaborado pelo autor

Entre os gastos assistenciais duas são relevantes em termos financeiros, o programa Leve Leite $^{22}$ que liquidou R\$ 298 milhões e uniforme escolar que alcançou R\$ 48 milhões. Os gastos com cultura e esporte ocorrem, em especial, nos Centros de Educação Unificados (CEUs), com eventos e atividades artísticas foram aplicados R\$ 10,9 milhões, com o Projeto Vocacional e o Programa de Iniciação Artística, que formam turmas de Teatro, Música, Dança, Artes Visuais e Literatura em bibliotecas, teatros, Casas de Cultura, Centros Culturais e CEUs, os valores liquidados foram de R\$ 1,7 milhão e R\$ 1,2 milhão, respectivamente. Na parte esportiva o maior gasto se refere aos serviços de socorro e salvamento nas piscinas dos CEUs que totalizou R \$ 5,4 milhões.

\footnotetext{
${ }^{22}$ O programa leve leite consiste na distribuição de $2 \mathrm{~kg}$ de leite em pó por mês para crianças e adolescentes com até 16 anos de idade que mantêm mais de 90\% de frequência escolar. Em 2017 o programa foi reformulado, somente crianças com até 6 anos de idade de famílias registradas no cadúnico poderiam receber $1,2 \mathrm{~kg}$ de leite em pó.
} 
Tabela 24 - Despesas assistenciais, culturais e esportivas segundo insumos detalhados Secretaria Municipal de Educação, 2015

\begin{tabular}{l|rr}
\hline \multirow{2}{*}{ Finalidade/ Insumos detalhados } & \multicolumn{2}{c}{ Valores Liquidados } \\
\cline { 2 - 3 } & \multicolumn{1}{c}{ Nominal } & \multicolumn{1}{c}{$\%$} \\
\hline Assistencial & $346.856 .310,85$ & \\
Leve Leite & $298.114 .622,53$ & $85,9 \%$ \\
Uniforme Escolar & $48.647 .079,24$ & $14,0 \%$ \\
Distribuição de equipamentos para pessoas com mobilidade reduzida & $94.609,08$ & $0,0 \%$ \\
\hline Cultural & $15.159 .308,99$ & \\
Eventos e Atividades Artísticas & $10.947 .758,36$ & $72,2 \%$ \\
Projeto Vocacional & $1.728 .144,00$ & $11,4 \%$ \\
PIÁ - Programa de Iniciação Artística & $1.226 .596,80$ & $8,1 \%$ \\
Semana do Hip Hop & $609.900,00$ & $4,0 \%$ \\
Virada Cultural & $484.479,83$ & $3,2 \%$ \\
Técnicos na Área Cultural e Artística & $141.630,00$ & $0,9 \%$ \\
Apresentação de Contação de Histórias & $20.800,00$ & $0,1 \%$ \\
\hline Esportiva & $10.856 .019,42$ & \\
Serviços de Socorro e Salvamento & $5.462 .767,23$ & $50,3 \%$ \\
Olimpíadas Estudantis e InterCEUs & $3.021 .358,60$ & $27,8 \%$ \\
Programa Clube Escola - Temático de Lutas & $1.557 .946,57$ & $14,4 \%$ \\
Eventos, Atividades e Materiais Esportivos & $813.947,02$ & $7,5 \%$ \\
\hline Fonte: SOF/Secretaria Municipal da Fazenda & & \\
Elaborado pelo autor & &
\end{tabular}

Na sequência, 61,4\% dos $\mathrm{R}$ \$ 8,6 bilhões dos gastos com finalidade educacional são destinados ao pagamento de pessoal, $21,8 \%$ para bens e serviços, e temos ainda, $\mathrm{R} \$ 1,4$ bilhão com despesas decorrentes de contratos de terceirização da atividade fim com entidades conveniadas com o setor público (Tabela 18). A maioria dos contratos de terceirização da gestão é referente ao atendimento de crianças em creches conveniadas $(97,1 \%)$, mas há contratos para o atendimento na educação especial, na educação de jovens e adultos e na educação indígena. Os contratos de terceirização não permitem identificar os insumos utilizados para manutenção e desenvolvimento do ensino, assim, a análise de custo se concentrará na rede de atendimento direta. Ao retirar as despesas com contratos de terceirização da atividade fim, se verifica que os gastos de pessoal representam $73,8 \%$ do gasto com educação na rede direta. 
Tabela 25 - Valores liquidados dos gastos com finalidade educacional segundo categoria econômica. Secretaria Municipal de Educação, 2015

\begin{tabular}{l|c|c|c|c}
\hline \multirow{2}{*}{ Categoria Econômica } & \multicolumn{3}{c}{ Valores Liquidados } \\
\cline { 2 - 5 } & Rede Direta e Conveniada & \multicolumn{2}{c}{ Rede Direta } \\
\cline { 2 - 5 } & Nominal & $\mathbf{\%}$ & Nominal & $\%$ \\
\hline Pessoal & $5.300 .646 .864,92$ & $61,4 \%$ & $5.300 .646 .864,92$ & $73,8 \%$ \\
Bens e Serviços & $1.879 .945 .242,08$ & $21,8 \%$ & $1.879 .945 .242,08$ & $26,2 \%$ \\
Contratos de Tercerização da Atividade Fim & $1.451 .599 .268,59$ & $16,8 \%$ & \\
Convênio - Creche & $1.413 .506 .469,87$ & & & \\
Convênio - Educação Especial & $28.545 .553,32$ & & & \\
Convênio - MOVA & $8.259 .700,49$ & & & \\
Convênio - Centro de Educação e Cultura Indígena & $1.287 .544,91$ & & & \\
\hline Total & $8.632 .191 .375,59$ & $100,0 \%$ & $7.180 .592 .107,00$ & $100,0 \%$ \\
\hline
\end{tabular}

Fonte: SOF/Secretaria Municipal da Fazenda

Elaborado pelo autor

Em relação às gastos de pessoal os professores representam $80 \%$ dos valores liquidados ( $\mathrm{R} \$ 4,3$ bilhões), em um segundo patamar estão tanto os gestores e especialistas como os profissionais de apoio, que recebem $\mathrm{R} \$ 511$ milhões e $\mathrm{R} \$ 510$ milhões, respectivamente. Uma pequena parcela de $0,07 \%$ ocorre por meio de contratos de locação de mão de obra, que se encontram estagiários, coordenadores de pólo, agente de recreação, oficineiros, instrutores e intérpretes de libras e instrutores de instrumentos de metais e percussão. As despesas liquidadas de pessoal com trabalhadores em unidades educacionais representam 93,1\% do total, o restante, $\mathrm{R} \$ 366,7$ milhões, ocorre com trabalhadores fora das unidades escolares, deste montante impressiona o valor correspondente aos professores em postos administrativos, um total de R\$178,9 milhões (Tabela 26).

Tabela 26 - Valores liquidados de gastos educacionais de pessoal

Secretaria Municipal de Gestão, 2015

\begin{tabular}{|c|c|c|c|c|c|c|}
\hline & \multirow{2}{*}{\multicolumn{4}{|c|}{ Local de Trabalho }} & \multirow{3}{*}{\multicolumn{2}{|c|}{ Total }} \\
\hline \multirow{3}{*}{ Tipo de contração e função } & & & & & & \\
\hline & \multicolumn{2}{|c|}{ Escola } & \multicolumn{2}{|c|}{ Fora da Escola } & & \\
\hline & Valor & $\%$ & Valor & $\%$ & Valor & $\%$ \\
\hline \multirow{2}{*}{ Finalidade Educacional } & $4.933,9$ & $100,0 \%$ & 366,7 & $100,0 \%$ & $5.300,6$ & $100,0 \%$ \\
\hline & $93,1 \%$ & & $6,9 \%$ & & $100,0 \%$ & \\
\hline \multirow{2}{*}{$\begin{array}{l}\text { Servidores e Funcionários da Administração Municipal } \\
\text { Docente }\end{array}$} & $4.899,9$ & $99,3 \%$ & 365,4 & $99,7 \%$ & $5.265,3$ & $99,3 \%$ \\
\hline & $4.063,7$ & $82,4 \%$ & 178,9 & $48,8 \%$ & $4.242,6$ & $80,0 \%$ \\
\hline Gestor/Especialista & 391,1 & $7,9 \%$ & 120,8 & $32,9 \%$ & 511,9 & $9,7 \%$ \\
\hline Profissionais de Apoio & 445,0 & $9,0 \%$ & 65,8 & $17,9 \%$ & 510,8 & $9,6 \%$ \\
\hline Outros Serviços de Terceiros & 34,0 & $0,7 \%$ & 1,3 & $0,3 \%$ & 35,3 & $0,7 \%$ \\
\hline Bolsa-Auxílio para Contratação de Estagiários & 24,4 & $0,5 \%$ & 1,1 & $0,3 \%$ & 25,5 & $0,5 \%$ \\
\hline Auxílio Transporte a Estagiários & 4,5 & $0,1 \%$ & 0,2 & $0,1 \%$ & 4,6 & $0,1 \%$ \\
\hline Coordenador de pólo, Agente de Recreação e Oficineiros & 2,9 & $0,1 \%$ & & $0,0 \%$ & 2,9 & $0,1 \%$ \\
\hline Instrutor/Intérprete de Libras/Sinais & 2,1 & $0,0 \%$ & & $0,0 \%$ & 2,1 & $0,0 \%$ \\
\hline Instrutor de Instrumentos de Metais e Percussão & 0,2 & $0,0 \%$ & & $0,0 \%$ & 0,2 & $0,0 \%$ \\
\hline
\end{tabular}

Fonte: SOF/Secretaria Municipal da Fazenda e Secretaria Municipal de Gestão.

Elaborado pelo autor.

Como vimos os bens e serviços totalizam $\mathrm{R} \$ 1,8$ bilhão, os insumos mais representativos são os relacionados a programas de acesso e permanência estudantil, com um 
gasto de R\$ 675 milhões (36\%), contribuem para este resultado os gastos com Merenda Escolar (R\$ 492 milhões) e o programa de Transporte Escolar Gratuito (R\$ 172 milhões).

Os serviços de manutenção e apoio também representam quase um terço das despesas liquidadas com bens e serviços, neste grupo os dois componentes principais são: serviços e materiais de limpeza e conservação com $\mathrm{R} \$ 385$ milhões e vigilância e segurança com R\$169 milhões.

O terceiro grupo se refere a gastos com edificações, tanto recursos para reformas e conservação, como para construção, aquisição e locação, o total apurado foi de R $\$ 331,9$ milhões. Neste grupo cabe a diferenciação entre manutenção e desenvolvimento, os gastos com a ampliação permanente de acesso à educação, como construção e aquisição de imóveis foram classificadas como desenvolvimento, enquanto reformas de prédios e custeio com aluguéis classificados como de manutenção, ao final temos a aplicação de $\mathrm{R}$ \$ 215,2 milhões com desenvolvimento e R \$116,6 milhões com manutenção.

Os serviços básicos representam 7,2\% das despesas liquidadas com bens e serviços (R\$ 135 milhões), sendo mais representativos os gastos com água e esgoto (R\$ 72,4 milhões) e energia elétrica (R \$ 50,7 milhões). Neste ponto surpreende o baixo valor referente a despesa liquidada com internet ( $\mathrm{R} \$ 4,6$ milhões), contudo, compreende-se que parte deste gasto está expressa na categoria tecnologia da informação que totalizam R 48 milhões, por meio dos fornecedores não foi possível separar o que de fato era infraestrutura de sistemas administrativos da Secretaria Municipal de Educação da rede de acesso à internet nas escolas.

Outros R\$ 48,7 milhões foram destinados para unidades escolares por meio do Programa de Transferência de Recursos Financeiros (PTRF). O PTRF ${ }^{23}$ é semelhante ao PDDE do governo federal que transfere diretamente para as unidades escolares, por meio das Associações de Pais e Mestres das unidades educacionais, recursos financeiros para execução de pequenos serviços ou compra de bens, estão entre as possibilidades de despesa: i) aquisição de material permanente; ii) aquisição de material de consumo necessário ao funcionamento da unidade educacional; iii) manutenção, conservação e pequenos reparos da unidade educacional; iv) desenvolvimento de atividades educacionais; v) implementação de projetos pedagógicos da unidade educacional; e vi) contratação de serviços.

É notório que a transversalidade de certos programas impede uma contabilização restrita de parte dos gastos. Além das despesas liquidadas com internet e do PTRF há a contabilização de R \$ 30 milhões armazenagem, logística e locomoção, que pode ser realizada

\footnotetext{
${ }^{23}$ BRASIL. Lei ${ }^{\circ} 13.991$, de 10 de junho de 2005. Institui o programa de transferência de recursos financeiros às associações de pais e mestres das unidades educacionais da rede municipal de ensino, 2005.
} 
com a merenda escolar, distribuição de livros didáticos, uniformes ou outros insumos, como o contrato com os fornecedores trata de armazenagem e distribuição em metros cúbicos de qualquer material não é possível detalhar este item.

Os demais gastos não atingem $1 \%$ dos bens de serviços, ações e materiais de apoio didático-pedagógico educacional com R $\$ 14,5$ milhões, formação de recursos humanos com $\mathrm{R}$ \$ 9,3 milhões, publicidade institucional registra $\mathrm{R}$ \$ 5,1 milhões e políticas de avaliação escolar com R \$3,8 milhões (Tabela 27).

Tabela 27 - Valores liquidados de insumos segundo forma de aplicação no ensino Secretaria Municipal de Educação, 2015

\begin{tabular}{|c|c|c|c|c|}
\hline \multirow[t]{2}{*}{ Insumos/ Insumos Detalhados } & \multicolumn{2}{|c|}{$\begin{array}{c}\text { Aplicação no } \\
\text { Ensino }\end{array}$} & \multicolumn{2}{|c|}{ Total } \\
\hline & Desenv. & Manut. & Nominal & $\%$ \\
\hline Acesso e Permanência Estudantil & & 675,9 & 675,9 & $36,0 \%$ \\
\hline Merenda Escolar & & 492,6 & 492,6 & $26,2 \%$ \\
\hline Transporte Escolar & & 172,6 & 172,6 & $9,2 \%$ \\
\hline Material Escolar & & 10,7 & 10,7 & $0,6 \%$ \\
\hline Serviços de Manute nção e Apoio & & 571,4 & 571,4 & $30,4 \%$ \\
\hline Serviços e Materiais de Limpeza e Conservação & & 385,0 & 385,0 & $20,5 \%$ \\
\hline Guarda, Vigilância Ostensiva e Segurança & & 169,3 & 169,3 & $9,0 \%$ \\
\hline Aquisição, Refor. e Manut. de Equipamentos & & 6,9 & 6,9 & $0,4 \%$ \\
\hline Serviços e Materiais de Copa e Cozinha & & 5,3 & 5,3 & $0,3 \%$ \\
\hline Serv. e Materiais de Apoio Administrativo, Técnico e Operacional & & 4,9 & 4,9 & $0,3 \%$ \\
\hline \multicolumn{5}{|l|}{ Aquisição, Locação, Cons trução, Ampliação e Reformas de } \\
\hline Edificações & 215,2 & 116,6 & 331,9 & $17,7 \%$ \\
\hline Construção de Edificações & 203,1 & & 203,1 & $10,8 \%$ \\
\hline Reforma e Conservação Predial & & 101,5 & 101,5 & $5,4 \%$ \\
\hline Locação de Imóveis & & 15,1 & 15,1 & $0,8 \%$ \\
\hline Aquisição de Imóveis & 12,1 & & 12,1 & $0,6 \%$ \\
\hline Serviços Básicos & & 135,3 & 135,3 & $7,2 \%$ \\
\hline Serviços de Água e Esgoto & & 72,4 & 72,4 & $3,8 \%$ \\
\hline Serviços de Energia Elétrica e Iluminação Pública & & 50,7 & 50,7 & $2,7 \%$ \\
\hline Telefonia Fixa e Móvel & & 7,3 & 7,3 & $0,4 \%$ \\
\hline Serviço de Instalação, Ampliação de Sist. de Telefonia/Teleinformática & & 4,6 & 4,6 & $0,2 \%$ \\
\hline Gás Liquefeito de Petróleo & & 0,4 & 0,4 & $0,0 \%$ \\
\hline Trans fe rência Financeira & & $\mathbf{5 4 , 0}$ & $\mathbf{5 4 , 0}$ & $2,9 \%$ \\
\hline Transferência de Recursos para as Unidades Educacionais - PTRF & & 48,7 & 48,7 & $2,6 \%$ \\
\hline Devolução de Recursos ao FNDE & & 5,3 & 5,3 & $0,3 \%$ \\
\hline Tecnologia da Informação & $\mathbf{1 4 , 8}$ & $\mathbf{3 3 , 3}$ & 48,0 & $2,6 \%$ \\
\hline Armazenage m, Logística e Locomoção & & 30,7 & 30,7 & $1,6 \%$ \\
\hline Ações e materiais de apoio Didático-Pedagógico & & 14,5 & 14,5 & $\mathbf{0 , 8 \%}$ \\
\hline Formação de Recursos Humanos & & 9,3 & 9,3 & $\mathbf{0 , 5 \%}$ \\
\hline Publicidade Institucional & & 5,1 & 5,1 & $\mathbf{0 , 3 \%}$ \\
\hline Políticas de Avaliação Escolar & & $\mathbf{3 , 8}$ & $\mathbf{3 , 8}$ & $\mathbf{0 , 2 \%}$ \\
\hline Total & 230,0 & $1.649,9$ & $1.879,9$ & $100,0 \%$ \\
\hline
\end{tabular}

Fonte: SOF/Secretaria Municipal da Fazenda 
A tabela 28 sintetiza todos os gastos aplicadas ao ensino na Secretaria Municipal de Educação, inclui os custos com manutenção e desenvolvimento do ensino liquidadas em outros órgãos, diferencia os gastos da rede direta com a rede conveniada, tanto em relação ao contrato de terceirização como os gastos de pessoal com trabalhadores locados na SME e nas DRE, e ainda, calcula o valor corresponde para cada etapa de ensino. 
Tabela 28 - Resumo do gasto com manutenção e desenvolvimento do ensino Secretaria Municipal de Educação e outros órgãos, 2015

\begin{tabular}{|c|c|c|c|c|c|}
\hline \multirow{2}{*}{$\begin{array}{c}\text { Órgão, Finalidade, Manutenção e Desenvolvimento } \\
\text { do Ensino, Tipo de Rede, Categoria Econômica, } \\
\text { Insumos e Insumos Detalhados }\end{array}$} & \multicolumn{4}{|c|}{ Etapa de Ensino } & \multirow{2}{*}{ Total } \\
\hline & Creche & $\begin{array}{c}\text { Pré- } \\
\text { escola }\end{array}$ & $\begin{array}{l}\text { Ensino } \\
\text { Fund. }\end{array}$ & \begin{tabular}{|l|} 
Ensino \\
Médio
\end{tabular} & \\
\hline \multicolumn{5}{|l|}{ Encargos Gerais do Município } & $2.105,5$ \\
\hline \multicolumn{5}{|l|}{ Insuficiência financeira de aposentadorias e pensões } & $1.075,3$ \\
\hline Obrigações e contribuições patronais & 211,1 & 284,8 & 530,3 & 3,9 & $1.030,2$ \\
\hline \multicolumn{3}{|l|}{ Secretaria Municipal de Transportes } & 132,1 & 163,8 & 295,9 \\
\hline \multicolumn{3}{|c|}{ Subsídio da tarifa do sistema municipal de transporte dos estudantes } & 132,1 & 163,8 & 295,9 \\
\hline \multicolumn{5}{|c|}{ Secretaria Municipal de Educação } & $9.007,9$ \\
\hline \multicolumn{5}{|l|}{ Assistencial } & 346,9 \\
\hline \multicolumn{5}{|l|}{ Cultural } & 15,2 \\
\hline \multicolumn{5}{|l|}{ Esportiva } & 10,9 \\
\hline \multicolumn{5}{|l|}{ Educacional } & $8.632,2$ \\
\hline \multicolumn{5}{|l|}{ Desenvolvimento do Ensino } & 230,0 \\
\hline \multicolumn{5}{|l|}{ Aquisição e Construção de Edificações } & 215,2 \\
\hline \multicolumn{5}{|l|}{ Tecnologia da informação } & 14,8 \\
\hline \multicolumn{5}{|l|}{ Manutenção do Ensino } & $8.402,2$ \\
\hline \multicolumn{5}{|l|}{ Rede Direta } & $6.796,1$ \\
\hline Pessoal & $1.055,3$ & $1.423,7$ & $2.650,9$ & 19,6 & $5.149,4$ \\
\hline Servidores e Funcionários & $1.048,8$ & $1.414,8$ & $2.631,0$ & 19,5 & $5.114,1$ \\
\hline Docente & 837,4 & $1.121,2$ & $2.193,5$ & 16,5 & $4.168,6$ \\
\hline Gestor/Especialista & 87,9 & 154,1 & 218,4 & 1,5 & 461,9 \\
\hline Profissionais de Apoio & 123,6 & 139,4 & 219,2 & 1,4 & 483,6 \\
\hline Outros Serviços de Terceiros & 6,4 & 8,9 & 19,8 & 0,1 & 35,3 \\
\hline Bens e Serviços & 347,1 & 480,2 & 814,4 & 5,0 & $1.646,7$ \\
\hline Acesso e Permanência Estudantil & 73,6 & 238,4 & 358,8 & 1,9 & 672,7 \\
\hline Merenda Escolar & 71,4 & 154,2 & 265,2 & 1,8 & 492,6 \\
\hline Transporte Escolar & 1,5 & 81,7 & 88,5 & 0,1 & 171,8 \\
\hline Material Escolar & 0,7 & 2,4 & 5,1 & 0,0 & 8,2 \\
\hline Serviços de Manutenção e Apoio & 167,1 & 142,2 & 260,3 & 1,8 & 571,4 \\
\hline Serviços e Materiais de Limpeza e Conservação & 112,6 & 95,8 & 175,4 & 1,2 & 385,0 \\
\hline Guarda, Vigilância Ostensiva e Segurança & 49,5 & 42,1 & 77,1 & 0,5 & 169,3 \\
\hline Aquisição, Refor. e Manut. de Equipamentos & 2,0 & 1,7 & 3,1 & 0,0 & 6,9 \\
\hline Serviços e Materiais de Copa e Cozinha & 1,5 & 1,3 & 2,4 & 0,0 & 5,3 \\
\hline Serv. e Mat. de Apoio Adm., Téc. e Operacional & 1,4 & 1,2 & 2,3 & 0,0 & 4,9 \\
\hline Locação, Ampliação e Reforma de Edificações & 34,1 & 29,0 & 53,1 & 0,4 & 116,6 \\
\hline Serviços Básicos & 39,6 & 33,7 & 61,6 & 0,4 & 135,3 \\
\hline Transferência Financeira & 15,8 & 13,4 & 24,6 & 0,2 & 54,0 \\
\hline Tecnologia da Informação & 6,1 & 8,4 & 18,7 & 0,1 & 33,3 \\
\hline Armazenagem, Logística e Locomoção & 5,6 & 7,7 & 17,2 & 0,1 & 30,7 \\
\hline Ações e materiais de apoio Didático-Pedagógico & 2,6 & 3,6 & 8,1 & 0,1 & 14,5 \\
\hline Formação de Recursos Humanos & 1,7 & 2,3 & 5,2 & 0,0 & 9,3 \\
\hline Publicidade Institucional & 0,9 & 1,3 & 2,8 & 0,0 & 5,1 \\
\hline Políticas de Avaliação Escolar & & & 3,8 & & 3,8 \\
\hline Rede Conveniada & & & & & $1.606,1$ \\
\hline Pessoal & & & & & 151,2 \\
\hline Servidores e Funcionários & & & & & 151,2 \\
\hline Bens e Serviços & & & & & 3,3 \\
\hline Acesso e Permanência Estudantil & & & & & 3,3 \\
\hline Contratos de Tercerização da Atividade Fim & & & & & $1.451,6$ \\
\hline Demais gastos & & & & & 2,8 \\
\hline
\end{tabular}

Fonte: SOF/Secretaria Municipal da Fazenda

Elaborado pelo autor 
Enfim, tratemos do comparativo dos insumos por etapa de ensino da Prefeitura Municipal de São Paulo em relação ao CAQi. Os custos de pessoal nas creches estão próximos, enquanto na PMSP a participação era de 78,5\% o CAQi registra 76,7\%. Nas etapas seguintes à distância aumenta, o patamar identificado com custo de pessoal com o CAQi é menor, fica entre 70,0\% e 71,6\%, enquanto na PMSP representa 78,1\% e 77,1\%, na préescola e no ensino fundamental, respectivamente.

A diferença deriva de três prerrogativas adotadas pelos pesquisadores do CAQi que não se expressam na carreira docente em São Paulo, a primeira é de uma carreira única em que um profissional com a formação equivalente receberia remuneração semelhante, isto não se aplica para a rede municipal de São Paulo, há inúmeros cargos com áreas de atuação diferentes, com uma política de remuneração específica que não guarda coerência com a formação inicial. A segunda é de que o contingente de professores do ensino fundamental ingressou na carreira a mais tempo, e por isso, estão em estágio mais avançado na carreira do que os professores em creches. E a terceira, é de que a remuneração inicial dos docentes no município de São Paulo é superior ao que foi proposto pelo CAQi.

Por outro lado, o peso da alimentação escolar não apresenta grande disparidade na préescola e ensino fundamental, mas é praticamente o dobro nas creches, de 4,4\% na PMSP e de $8,6 \%$ do CAQi. Para mensurar os custos com merenda foram associados às despesas liquidadas por aluno ajustadas pela jornada de permanência na unidade educacional. Neste sentido a diferença entre jornadas da creche em relação às demais etapas estaria equacionada, assim, o resultado demonstra que o CAQi contabiliza valor significativamente superior ao verificado na cidade de São Paulo.

Os serviços básicos oscilam de $1,5 \%$ a 2,5\% na PMSP e de 2,1\% a 2,9\% no CAQi, a diferença seria menor se considerado que parte expressiva dos gastos da PMSP com tecnologia da informação poderiam ser apropriados como acesso à internet e contabilizados como serviços básicos, a participação com tecnologia da informação varia de $0,4 \% 0,5 \%$.

Os custos com material e serviços de escritório e com aquisição, reforma e manutenção de equipamentos não ultrapassa $0,2 \%$ na PMSP, enquanto no CAQi o custo pode representar 3,5\% nas séries finais do ensino fundamental, resultado oposto ao verificado em relação aos materiais e serviços de limpeza, copa e conservação, nas creches da administração municipal os gastos representam $7,1 \%$ dos custos, na pré-escola e ensino fundamental atingem $4,4 \%$ e $4,3 \%$, respectivamente. No CAQi os gastos com a compra de materiais de limpeza não chegam a $1,0 \%$, o custo seria baixo pois os gastos com os trabalhadores estão previstas no custo de pessoal, ou seja, o patamar de custo com pessoal seria ainda mais baixo 
se considerarmos a possibilidade terceirização de atividades-meio, como os serviços de limpeza.

A soma dos insumos materiais escolares com ações e materiais de apoio didáticopedagógico apresenta a maior discrepância, enquanto na pré-escola e nas séries iniciais do ensino fundamental a participação é de 11,2\% na matriz do CAQi, na PMSP a participação é de apenas $0,3 \%$. Este resultado pode ser entendido tanto como a baixa aplicação nestes insumos, como também decorrente dos programas federais, como Programa Nacional do Livro Didático (PNLD) o Programa Nacional Biblioteca da Escola (PNBE) e o Programa Dinheiro Direto na Escola (PDDE), que encaminham recursos ou produtos diretamente para as unidades escolares, desta maneira, tais custos não são contabilizados no orçamento municipal.

Os recursos dispendidos com programas de formação de recursos humanos não ultrapassaram $0,1 \%$ em nenhuma etapa de ensino, distante da previsão do CAQi de aplicação de 1,5\% a 2,7\%. Tanto a metodologia do CAQi como a execução orçamentária da prefeitura não contabiliza as horas de atividade docente dedicadas para formação nas unidades escolares, conforme definições do cargo e da carreira.

Por fim, cabe destacar o conjunto de insumos encontrados na execução orçamentária que não foram considerados pelo CAQi, equivalente a 4,8\% em creches, 7,1\% na pré-escola e $8,8 \%$ no ensino fundamental. Nas creches o principal item se refere aos gastos com guarda, vigilância ostensiva e segurança $(3,1 \%)$, enquanto na pré-escola e no ensino fundamental os gastos com transporte escolar chegam a 3,7\% e 5,3\% (Tabela 29). 
Tabela 29 - Análise comparada da participação dos insumos na definição dos custos com manutenção e desenvolvimento do ensino na rede municipal direta de São Paulo em relação ao CAQi, 2015

\begin{tabular}{|c|c|c|c|c|c|c|c|}
\hline \multirow{3}{*}{ Ins umos } & \multicolumn{3}{|c|}{ PMSP } & \multicolumn{4}{|c|}{ CAQi } \\
\hline & \multirow{2}{*}{ Creche } & \multirow{2}{*}{$\begin{array}{c}\text { Pré- } \\
\text { es cola }\end{array}$} & \multirow{2}{*}{$\begin{array}{c}\text { Ensino } \\
\text { Fund. }\end{array}$} & \multirow{2}{*}{ Creche } & \multirow{2}{*}{$\begin{array}{c}\text { Pré- } \\
\text { escola }\end{array}$} & \multicolumn{2}{|c|}{$\begin{array}{c}\text { Ensino } \\
\text { Fundamental }\end{array}$} \\
\hline & & & & & & $\begin{array}{l}\text { Séries } \\
\text { Iniciais }\end{array}$ & $\begin{array}{l}\text { Séries } \\
\text { Finais }\end{array}$ \\
\hline Pessoal & $\mathbf{7 8 , 5 \%}$ & $78,1 \%$ & $77,1 \%$ & $76,7 \%$ & $71,3 \%$ & $\mathbf{7 0 , 0} \%$ & $71,6 \%$ \\
\hline Servidores e Funcionários & $65,4 \%$ & $65,0 \%$ & $64,3 \%$ & $64,1 \%$ & $59,6 \%$ & $58,3 \%$ & $60,0 \%$ \\
\hline Obrigações e contribuições patronais/Encargos sociais & $13,1 \%$ & $13,0 \%$ & $12,9 \%$ & $12,6 \%$ & $11,7 \%$ & $11,7 \%$ & $11,6 \%$ \\
\hline Bens e serviços & $21,5 \%$ & $21,9 \%$ & $22,9 \%$ & $23,3 \%$ & $28,7 \%$ & $\mathbf{3 0 , 0 \%}$ & $28,4 \%$ \\
\hline Merenda Escolar/ Alimentação Escolar & $4,4 \%$ & $7,0 \%$ & $6,4 \%$ & $8,6 \%$ & $7,3 \%$ & $8,8 \%$ & $6,3 \%$ \\
\hline Serviços Básicos/ Água,Luz,Telefone & $2,5 \%$ & $1,5 \%$ & $1,5 \%$ & $2,9 \%$ & $2,7 \%$ & $2,7 \%$ & $2,1 \%$ \\
\hline $\begin{array}{l}\text { Serv. e Materiais de Apoio Administrativo, Técnico e } \\
\text { Operacional/Material de Escritório }\end{array}$ & $0,1 \%$ & $0,1 \%$ & $0,1 \%$ & $0,4 \%$ & $0,7 \%$ & $0,7 \%$ & $0,7 \%$ \\
\hline Serv. e Mat. de Limpeza, de Copa e Cozinha e Conservação & $7,1 \%$ & $4,4 \%$ & $4,3 \%$ & $0,9 \%$ & $0,7 \%$ & $0,7 \%$ & $0,7 \%$ \\
\hline Aquisição, Reforma e Manutenção de Equipamentos & $0,1 \%$ & $0,1 \%$ & $0,1 \%$ & $1,2 \%$ & $2,7 \%$ & $2,7 \%$ & $2,8 \%$ \\
\hline Locação, Ampliação e Reforma de Escolas & $2,1 \%$ & $1,3 \%$ & $1,3 \%$ & $1,7 \%$ & $1,6 \%$ & $1,3 \%$ & $2,5 \%$ \\
\hline Material Escolar/ Materiais Pedagógicos e brinquedos & $0,0 \%$ & $0,1 \%$ & $0,1 \%$ & $2,4 \%$ & $5,6 \%$ & $5,6 \%$ & $5,9 \%$ \\
\hline Ações e materiais de apoio Didático-Pedagógico & $0,2 \%$ & $0,2 \%$ & $0,2 \%$ & $2,4 \%$ & $5,6 \%$ & $5,6 \%$ & $5,9 \%$ \\
\hline Formação de Recursos Humanos & $0,1 \%$ & $0,1 \%$ & $0,1 \%$ & $2,7 \%$ & $1,9 \%$ & $2,0 \%$ & $1,5 \%$ \\
\hline Subtotal Bens e Serviços - despesas similares & $16,6 \%$ & $14,9 \%$ & $14,1 \%$ & & & & \\
\hline Subsídio da tarifa do SMT aos estudantes & $0,0 \%$ & $0,0 \%$ & $3,2 \%$ & & & & \\
\hline Transporte Escolar & $0,1 \%$ & $3,7 \%$ & $2,1 \%$ & & & & \\
\hline Guarda, Vigilância Ostensiva e Segurança & $3,1 \%$ & $1,9 \%$ & $1,9 \%$ & & & & \\
\hline Transferência Financeira & $1,0 \%$ & $0,6 \%$ & $0,6 \%$ & & & & \\
\hline Tecnologia da Informação & $0,4 \%$ & $0,4 \%$ & $0,5 \%$ & & & & \\
\hline Armazenagem, Logística e Locomoção & $0,3 \%$ & $0,4 \%$ & $0,4 \%$ & & & & \\
\hline Publicidade Institucional & $0,1 \%$ & $0,1 \%$ & $0,1 \%$ & & & & \\
\hline Políticas de Avaliação Escolar & $0,0 \%$ & $0,0 \%$ & $0,1 \%$ & & & & \\
\hline Subtotal Bens e Serviços - Outras despesas & $4,9 \%$ & $7,1 \%$ & $8,8 \%$ & & & & \\
\hline
\end{tabular}

O detalhamento da execução orçamentária da prefeitura municipal de São Paulo permitiu um avanço significativo na análise de custos, o investimento na sistematização eletrônica das informações associado a uma pequena equipe pode permitir análises mais refinadas, a padronização da adoção dos subelementos e itens de despesa para uma análise temporal, conjuntamente com uma base de dados qualificadas de contratos permitirá um salto analítico. Este resultado contrasta com a execução orçamentária dos estados, em relatório de pesquisa recente o Conselho Nacional de Secretários da Educação (CONSED) apreciou a execução orçamentária dos estados, a maior parte detalha a execução orçamentária somente até elemento de despesa, o que impossibilita qualquer esforço na análise de custos, e entre aqueles estados em que há detalhamento da despesa existe uma série de problemas, como "ausência de critérios para o agrupamento de despesas, a contabilização de gastos de uma mesma natureza de forma distinta, a impossibilidade de proceder ao rateio de despesas para cada etapa educacional" (CONSED, 2018). 
O maior gargalo na gestão municipal é a classificação em relação à manutenção e desenvolvimento do ensino, esta poderia ser equacionada com a definição de critérios para utilização das subfunções, tanto pela Secretaria Municipal de Educação como pelos demais órgãos que executam os recursos vinculados.

Ressalvado o limite do CAQi ser uma pesquisa com insumos e preços estimados em relação à análise de custos de um órgão municipal, e de que o primeiro se trata de uma pretensa regra nacional e o segundo da execução específica de um município, há razoabilidade no comparativo entre as pesquisas. Entre os pontos de maior disparidade, identifica-se que o volume de gastos com aposentadorias e transporte escolar seria suficiente para contrapor as pesquisas, contudo, o município de São Paulo regulamentou o expurgo dos aposentados na contabilização em MDE, portanto, a decisão mais razoável foi retirar tal gasto do comparativo direto.

Por outro lado, a opção metodológica do CAQi de incluir servidores para prestação de atividades meio contrasta com altos volumes liquidados da administração municipal com contratos de terceiros de vigilância e limpeza das unidades escolares. O peso relativo destes contratos indica a importância que um aprofundamento dos instrumentais de custos para permitir ao gestor público uma tomada de decisão com informações confiáveis sobre a melhor forma de executar as atividades meio.

Outro ponto relevante é a importância dada pelo CAQi aos custos com atividades de apoio didático-pedagógico e de formação de professores, enquanto o indicador estima que 13,3\% das despesas no ensino fundamental serão destinadas para este fim, no município de São Paulo a aplicação não ultrapassou $0,4 \%$ dos gastos. Isto demonstra que o aumento das despesas com educação pode influir sobre insumos recorrentes em detrimento daqueles que se caracterizam pela elevação da qualidade do ensino. 


\section{CONSIDERAÇÕES FINAIS E PROPOSIÇÕES}

O redesenho do financiamento da educação por meio da política de fundos retirou o isolamento dos entes em termos da política educacional, a diferença entre as redes de ensino reduziu drasticamente, tanto no aspecto da receita como da despesa. Municípios que tinham uma arrecadação com a cota parte do ICMS acima da média estadual, devido à concentração de determinada atividade econômica no território viram o seu orçamento encolher para beneficiar outros entes que não possuíam a mesma capacidade de arrecadação, bem como induziu governantes a ampliarem a respectiva rede de atendimento sob a pena de verem o cofre vazio. O recurso que antes estava disponível sem contrapartida correspondente da administração pública já não se encontrava reservado ao ente, não há dúvida de que houve diminuição da diferença de investimento por aluno nos estados.

No segundo momento, com a complementação da União consistente por meio do Fundeb a diferença entre os estados, pelo menos em relação ao acesso a recursos para manutenção e desenvolvimento do ensino, também diminuiu. A regra que vincula a contribuição da União à variação da contribuição dos estados e municípios é o ponto de maior inovação do fundo, o aporte financeiro foi tal que a complementação do Fundef no seu último ano de execução equivale a menos de $4 \%$ dos valores transferidos pela complementação do Fundeb em 2015, isto corrigindo os valores a preços de dezembro de 2015.

Entretanto, a nova lógica também produz iniquidades. A escolha de quais impostos e transferências vincular ao Fundeb não é neutra, ao selecionar apenas os impostos de competência estadual e federal para inclusão no fundo houve uma deliberação em razão da eficiência administrativa, ao delimitar a articulação para gestão das receitas dos Estados, do Distrito Federal e da União. Portanto, os tesouros municipais não aportam os impostos próprios no fundo. Isto torna o esforço de pequenos municípios maior do que das capitais e dos municípios com grau de urbanização mais elevado, pois enquanto se transfere ao fundo o FPM, de competência da União e que é mais representativo nos pequenos municípios, se exclui do fundo o IPTU e o ISS, impostos próprios de maior relevância nos municípios mais populosos. Esta escolha provoca perdas financeiras nos municípios com a menor capacidade financeira e administrativa enquanto os maiores registram resultados positivos.

Ademais, do mesmo modo que as matrículas não são contabilizadas no exercício de distribuição de recursos, os impostos municipais também não precisariam ser, a contabilização dos principais impostos municipais do ano anterior ao exercício financeiro do 
fundo contribuiria para redução das perdas financeiras dos municípios menores, mesmo que tal mecanismo fosse implementando a um grupo de municípios, como as capitais ou municípios com mais de 100 mil habitantes.

Enquanto na contabilização das receitas o Fundeb optou por uma estrutura concisa, no repasse de recursos a escolha foi por um modelo que realiza 23 ponderações nas matrículas. $\mathrm{O}$ fato reforça a compreensão da necessidade de destinação específica de recursos segundo parâmetros de elevada estima pelos educadores e pela sociedade, ampliando consideravelmente o escopo anterior que se restringia a cinco ponderações. Todavia, o reconhecimento não vem acompanhado de estudo que justifique as diferentes ponderações, não se trata de diminuir ou aumentar o número de ponderações, mas de qualificá-las. O custo de um aluno que cursa as séries iniciais do ensino fundamental é similar ao custo por criança em uma creche pública ${ }^{24}$, tanto em regime parcial como integral? O custo de educação em tempo integral no ensino médio é apenas 5 pontos percentuais superior ao da educação em tempo parcial. Segundo as ponderações do Fundeb para 2018 a resposta é afirmativa para ambas questões, mas não há elementos que justifiquem tais decisões.

Os autores do CAQi procuraram responder alguns destes pontos, sobretudo, diferenciar os custos das matriculas em creches das realizadas nos anos iniciais do ensino fundamental. Para tanto contabilizaram uma extensa lista de bens e serviços em cada etapa e afirmaram que o custo por criança em uma creche é 140\% superior ao custo apurado por aluno nas séries iniciais do ensino fundamental, no entanto, a comparação trata de uma creche em regime integral em relação ao ensino fundamental em regime parcial, ao equiparar a jornada a diferença se reduz para $20 \%$, o que não é pouco, visto que a margem de diferenciação em relação à matrícula de referência é de $30 \%$.

Esta pesquisa além de demonstrar a diferença de custo entre as etapas de ensino comprovou que a diferença entre ensino parcial e integral é maior do que a definida anualmente, ou seja, a jornada escolar é um fator determinante na formação dos custos do sistema escolar, se diferencia das demais ponderações pelo seu peso na definição dos custos, e permite o questionamento sobre a necessidade de categorização binária entre regime parcial e integral, em termos técnicos não há restrição para que seja aplicada, inicialmente, uma ponderação correspondente à jornada escolar efetiva dos estudantes, para depois aplicar a

\footnotetext{
24 Ademais, é importante ressaltar que as ponderações são publicadas anualmente pela Junta de Acompanhamento dos Fundos que foi instituída pela Medida Provisória n³39, de 28 de dezembro de 2006, entre as autoridades participantes estão: o Ministro da Educação, o presidente da UNDIME e o presidente do CONSED. Por fim, a ponderação das creches variou de 0,8 em 2007 para 1,0 em 2018.
} 
diferenciação por segmento, isto contribuiria para que a distribuição de recursos se aproximasse dos custos do sistema escolar.

O CAQi como fruto de um processo de mobilização de mais de 20 anos em defesa da educação de qualidade que incorporou em seu diagnóstico as condições de trabalho, os salários, o plano de carreira, a jornada de trabalho, a formação inicial e continuada dos trabalhadores e trabalhadoras, a infraestrutura das escolas, a disponibilidade de materiais pedagógicos, impondo limites ao número estudantes por sala de aula, se materializou como indicador para referenciar o gasto público em educação segundo critérios de qualidade.

Ao retomarmos que o motivo de geração do CAQi era subsidiar a defesa do aumento do financiamento educacional para "implementação de um conjunto articulado, duradouro e coerente de políticas que garantam uma educação pública de qualidade”, verifica-se que pelo direito simbólico o indicador alcançou êxito ao ser incluído na constituição federal o trecho de que a lei do plano nacional de educação deveria conter meta de "aplicação de recursos em educação como proporção do produto interno bruto" e constar no PNE a meta de ampliar o investimento público em educação pública de modo a atingir dez por cento do PIB ao final do decênio. Por outro lado, pelo direito instrumental, influenciou na criação da complementação da União ao Fundeb, no fim da DRU em manutenção e desenvolvimento do ensino, na aprovação da lei do piso salarial profissional nacional para os profissionais do magistério público da educação básica, na destinação de $75 \%$ dos royalties do petróleo e 50\% do Fundo Social do Pré-Sal para educação, dentre outras ações.

Contudo, o mérito do indicador na definição da despesa educacional como justificativa para ampliação de recursos para educação o aprisionou em um limbo em que qualquer aprimoramento metodológico poderia desqualificá-lo frente à opinião pública, tanto de especialistas como dos atores que atuavam neste campo, e os argumentos da sua viabilidade esbarravam nas condições objetivas do estado brasileiro. $\mathrm{O}$ volume de recursos necessário para implementar o projeto demandaria a abertura de um conflito distributivo entre os entes, mas as críticas aos poucos se concentraram na participação da União, o montante em disputa reduziu de tamanho devido à insistência sobre o baixo comprometimento da União em relação às políticas educacionais e da pretensa disponibilidade de recursos do ente para efetivação do mecanismo. Se por um lado a vinculação dos recursos do pré-sal representava um ganho da mobilização social em prol da educação, por outro, a proposta de quintuplicar a complementação da União ao Fundeb para efetivação do CAQi não se demonstra factível. 
Enquanto o CAQi cumpria o seu objetivo inicialmente pretendido, de contribuir para ampliação de recursos para as políticas educacionais, a sua função enquanto política pública ficou estagnada. A tentativa de regulação pelo Conselho Nacional de Educação por meio do Parecer $n^{\circ} 8 / 2010$ se mostrou inócua devido a busca pela compatibilização de interpretações divergentes sobre o rumo da política educacional. A contradição é exposta no artigo $7^{\circ}$ da proposta de resolução que comprime o conceito de qualidade da educação no alcance de determinado resultado no Ideb.

A identificação dos insumos essenciais ao desenvolvimento dos processos de ensino e aprendizagem que levem gradualmente a uma educação de qualidade, que pode ser inicialmente aferida para um IDEB igual a 6 , é a base de cálculo para o valor do CAQi (BRASIL, 2010).

A metodologia do CAQi de definir a cesta de bens e serviços buscou romper com a dificuldade na obtenção dos dados desagregados dos orçamentos públicos para estimar os custos de cada componente da educação básica. José Marcelino de Rezende Pinto foi diretor de tratamento e disseminação de informações educacionais do INEP de 2003 a 2004, acompanhou e coordenou o esforço da instituição na identificação das despesas e seus respectivos custos no período, mas os relatórios de pesquisa demonstraram a dificuldade na construção de um banco de dados com informações especificas sobre os custos das escolas brasileiras. Este resultado influenciou na definição metodológica do CAQi, de criar uma cesta de bens e serviços específica e atribuir o valor de cada item.

Neste sentido tanto os itens selecionados como os respectivos valores do indicador não possuem lastro na execução orçamentária das redes de ensino. Ao elencar os itens e atribuir valor a estes temos um descolamento do processo orçamentário, do planejamento à execução. Isto implica que o CAQi é uma definição estática, produzida por um rol de especialistas, e que a atribuição dos custos é realizada por uma estimativa sem respaldo em relação ao preço dos itens.

Se analisarmos em paralelo qualquer dos indicadores de preços, como o INPC do IBGE, identificamos que para definição da cesta de bens com seus respectivos valores é realizada uma pesquisa de orçamento familiar e depois para acompanhar a variação dos preços temos pesquisas mensais para mensuram o valor de cada item, por fim, se divulga a variação mensal do índice conforme o peso de cada item no orçamento familiar. Contudo existe uma limitação objetiva para realização desta pesquisa para identificação do custo das escolas na educação básica, o alto valor para custeá-la. 
Um dos fatores para reduzir o custo com determinada pesquisa das unidades escolares seria com a diminuição da distância entre as unidades escolares e os pesquisadores, a obtenção da execução orçamentária detalhada dos entes seria um passo para viabilizar tal iniciativa. Porém, a dificuldade para instalar um sistema de custos para permitir análises nacionais se torna uma tarefa mais complexa e onerosa do que a própria pesquisa de preços. A iniciativa mais próxima a este desenho ocorreu com o SIOPE, no qual todos os entes informam segundo parâmetros nacionais as despesas educacionais, mas o caráter declaratório do sistema é um empecilho ao avanço de tal possibilidade, uma vez que, as informações prestadas não são necessariamente compatíveis com a execução orçamentária, junto com a ausência de um mecanismo que permita o aprofundamento da qualidade dos dados informados.

Deste modo, os limites metodológicos do CAQi são compreensíveis frente ao esforço necessário de pesquisa para contabilização dos custos das redes de ensino como forma de subsidiar a tomada de decisão em relação aos segmentos expressos na política de fundos. Diferenciar custos segundo etapas e modalidades de ensino, da rede pública e da rede conveniada na educação infantil, ou mesmo da rede urbana em relação ao atendimento na zona rural são tarefas que exisgem um controle do orçamento público que simplesmente não existe.

O comparativo do CAQi frente à rede municipal de ensino de São Paulo, a rede como o maior aplicação por aluno do estado de São Paulo e certamente entre as maiores do país, demonstra que uma série de componentes do custo das unidades escolares possui pesos distintos dos apurados pelo CAQi e outros não são identificados pelo indicador. Lembrando que a proposta não representa uma média, mas um custo mínimo de aplicação para garantia de qualidade, e que o valor calculado do CAQi se aproximava do valor aluno do Fundeb no estado de São Paulo. Temos que, na hipótese de implementação do CAQi, ao distribuir valores próximos aos registrados no estado de São Paulo, a aplicação ocorreria de forma diferente da mensurada pelo indicador por causa das condições objetivas da rede de ensino da cidade de São Paulo, como ocorre com material escolar, ações e materiais de apoio didáticopedagógico e formação de professores que representam 13,3\% das despesas do CAQi no ensino fundamental enquanto na rede municipal de São Paulo o peso é de $0,4 \%$.

Além disso se há concordância de que não cabe ao CAQi engessar a administração pública com uma decisão de aplicação da parcela correspondente de cada componente, fato 
que não ocorre nem mesmo com o Fundeb, conclui-se que a finalidade CAQi estaria limitada ao seu objetivo inicial de ampliar os recursos para educação.

Uma outra alternativa seria utilizá-lo como métrica para a distribuição de recursos do fundo que venha a substituir o Fundeb. Porém, o CAQi não possui a diferenciação de preços para os 23 segmentos que orientam a atual distribuição de recursos. Diferencia apenas os custos por etapa de ensino e duração da jornada escolar, com uma tentativa de diferenciação por localização (urbana e rural).

Entretanto, as diretrizes construídas de forma participativa, as quais demonstram compreensão dos processos que impactam a educação pública não estariam expressas neste novo fundo. Elas se constituiriam somente em justificativas para construção de parte das ponderações. Construir diretrizes que serão desconsideradas sumariamente na distribuição de recursos gera um resultado nulo de todo processo de formulação e elaboração das políticas educacionais.

Não haveria outra forma de distribuir os recursos da educação em que ao menos parte destas diretrizes se tornassem parâmetros de distribuição de recursos, sem que houvesse uma vinculação pura e simples das despesas. Será que o equívoco que impede de estruturar sistemas de maior eficácia não está na matriz de distribuição de recursos criada pelo Fundef, reforçada pelo Fundeb, e que consta até no nome do CAQi, que é a utilização do aluno como eixo de distribuição de recursos.

O aluno é o maior benificiário da política educacional, e este lugar não cabe questionamento, mas os sistemas educacionais são estruturados por aulas, turmas e escolas. $\mathrm{O}$ professor é mais central aos sistemas de ensino do que o aluno quando se trata de custos, pelo menos enquanto preservarmos o ensino presencial na educação básica.

As três questões elencadas sobre a vinculação de recursos por aluno demonstram a fragilidade do mecanismo. Na ótica demográfica vincular às receitas dos entes aos alunos impede saltos qualitativos ao retirar recursos quando há recuos no contingente de pessoas em idade escolar, situação agravada pela composição de recursos conjunta de etapas de ensino em diferentes estágios de atendimento, o resultado é a asfixia dos entes com maior oferta de matrículas no ensino fundamental. $\mathrm{Na}$ ótica pedagógica a estrutura de financiamento privilegia o ente que introduz uma forma de organização de ensino que carrega o sistema de ensino de matrículas, ao optar por políticas rígidas de reprovação, o contingente de alunos acima da idade adequada cresce, gerando favorecimento tanto na relação intraestadual, como 
na divisão dos recursos da complementação da União, ao aumentar o contingente de matrículas o per capita do estado diminui, e dependendo da posição relativa em que o estado se encontra, a proposta pedagógica poderá definir se o estado receberá, ou não, a complementação da União. Pela ótica financeira se identifica que os custos atrelados ao estudante se concentram nos programas de acesso e permanência estudantil que possuem pequena participação nos custos totais do sistema escolar, assim, a variação do número de estudantes gera, no máximo, um aumento marginal dos custos educacionais, mas a receita vinculada ao estudante não possui essa diferenciação.

Para um país que aprovou um plano decenal da educação com metas objetivas de expansão do ensino em tempo integral continuar com um mecanismo de repasse de recursos que desestimula tal política se mostra contraditório. A alteração da pirâmide etária que poderia se tornar em uma oportunidade para o país apresentar uma melhoria substancial na qualidade do ensino em escala nacional se transformou em problema que trava o desenvolvimento das políticas educacionais.

Esta dissertação não propôs desenvolver uma nova estrutura de repasse de recursos do Fundeb, buscou, com todos os seus limites, identificar os pontos de esgotamento do atual sistema. No decorrer do trabalho determinados fatores demonstraram possuir maior relevância para uma eventual divisão dos custos do que o aluno, como professores, aulas, turmas e escolas. Se na distribuição de recursos por número de matrículas as redes se tornam instáveis com a redução do número de estudantes, a distribuição de recursos por turmas na educação básica, segundo um número mínimo e máximo de alunos, manteria equilibradas as receitas e despesas do ente, anulando efeitos indesejados de fechamento de turmas e escolas, o que reduziria a intensidade da variação das receitas decorrente dos diferentes estágios de desenvolvimento dos entes em cada etapa de ensino. Novas métricas para repasse de recursos permitiriam a incorporação de diretrizes na estrutura do fundo, induzindo novas práticas, o mesmo ímpeto que induziu a "municipalização selvagem" das matrículas com a introdução do Fundef poderia retornar em um novo desenho que incentivasse a abertura de turmas e a ampliação do tempo da jornada escolar. 


\section{REFERÊNCIAS}

ABRUCIO, Fernando Luiz. Contratualização e OS: reflexões teóricas e lições da experiência internacional. Debates GV Saúde, v. 1, 2006. Disponível em: < http://bibliotecadigital.fgv.br/ojs/index.php/debatesgvsaude/article/view/34957 > Acesso em $10 \operatorname{dez} 2018$

AFFONSO, R. B. A. Os municípios e os desafios da Federação no Brasil. São Paulo em Perspectiva, São Paulo, v. 10, n. 3, 1996.

AMARAL, Nelson C. O Fundeb em uma perspectiva comparada com o financiamento da educação básica nos países da OCDE e do BRICS. Em Aberto, Brasília, n.93, p.63-83, 2015. Disponível em: < http://emaberto.inep.gov.br/index.php/emaberto/article/view/2458> Acesso em $10 \mathrm{dez} 2018$.

ARAÚJO, Luiz. O CAQi e o novo papel da União no financiamento da Educação Básica. Paco Editorial. Jundiaí, SP, 2016.

BARROS, R. P. de; MENDONÇA, R.; SANTOS, D. D. de; QUINTAES, G. Determinantes do desempenho educacional no Brasil. Texto para discussão 834, IPEA, Rio de Janeiro, 2001. Disponível em: < http://www.ipea.gov.br/portal/index.php?option=com_content\&id=4075 $>$ Acesso em: $10 \mathrm{dez}$ 2018

BARROS, R. P. de. Como reduzir a desigualdade de oportunidades educacionais no Brasil: equalização dos gastos, da eficiência ou adequação à diversidade?. Seminário Internacional de Finanças da Educação Básica, Consed, Recife, mar. 2018.

BASTOS, Pedro Paulo Zahluth. Crescimento da dívida pública e política monetária no Brasil (1991-2014). Texto para Discussão. Unicamp. IE, Campinas, n. 273, abr. 2016.

BRASIL. Constituição Federal de 1988. Promulgada em 5 de outubro de 1988. Disponível em: $<$ http://www.planalto.gov.br/ccivil 03/Constituicao/Constituicao.htm $>$ Acesso em: 10 dez 2018.

BRASIL. Lei Orgânica do Município e São Paulo. São Paulo, SP, 1990.

BRASIL. Ministério da Educação. Balanço do Primeiro Ano do Fundef, Brasília, 1999.

BRASIL. Projeto de Lei $\mathbf{n}^{\mathbf{0}}$ 548/2001. Define as despesas que poderão ser consideradas no cômputo do percentual das receitas destinado a educação, nos termos do artigo 208 da Lei Orgânica do município de São Paulo, São Paulo, SP, 2001.

BRASIL. Emenda à Lei Orgânica n ${ }^{0} 24$ de 22 de dezembro de 2001. Introduz alterações e acrescenta dispositivos a Lei Orgânica do Município de São Paulo. São Paulo, SP, 2001.

BRASIL. MEC. INEP. Levantamento do custo-aluno-ano em escolas da educação básica que oferecem condições para a oferta de um ensino de qualidade. Plano de Trabalho. Brasília, DF, 2003. Não publicado. 
BRASIL. MEC. INEP. Problematização do conceito de qualidade presente na pesquisa custo-aluno-ano em escolas de Educação Básica que oferecem condições para a oferta de um ensino de qualidade. Brasília, DF: Instituto Nacional de Estudos e Pesquisas Educacionais Anísio Teixeira, 2004. Relatório de Pesquisa não publicado.

BRASIL. Lei $\mathrm{n}^{\mathrm{o}} 13.991$ de 10 de junho de 2005 . Institui o programa de transferência de recursos financeiros às associações de pais e mestres das unidades educacionais da rede municipal de ensino. São Paulo, SP, 2005.

BRASIL. MEC. INEP. Pesquisa nacional qualidade na educação. Brasília, DF: Instituto Nacional de Estudos e Pesquisas Educacionais Anísio Teixeira, 2006. v. 2.

BRASIL. MEC. Parecer do Conselho Nacional de Educação/Câmara de Educação Básica $\mathbf{n}^{\circ} 8$ de 2010. Estabelece normas para aplicação do inciso IX do artigo $4^{\circ}$ da Lei $n^{\circ}$ 9.394/96 (LDB), que trata dos padrões mínimos de qualidade de ensino para a Educação Básica. Maio de 2010 .

BRASIL. Carta-Compromisso pela Garantia do Direito à Educação de Qualidade - Uma convocação aos futuros governantes e parlamentares do Brasil, Agosto de 2010.

BRASIL. Resolução SE n. 60, de 30 de agosto de 2011. Instituiu a Comissão Paritária, com a finalidade de propor critérios e procedimentos para o sistema vigente de progressão de integrante do Quadro do Magistério. São Paulo, SP, Ago 2011.

BRASIL. Lei $\mathrm{n}^{\mathrm{o}}$ 15.963, de 15 de janeiro de 2014. Acrescenta referências à Escala de Padrões de Vencimentos do Quadro do Magistério Municipal, do Quadro dos Profissionais de Educação - QPE. São Paulo, SP, 2014a.

BRASIL. Lei $\mathrm{n}^{\mathrm{o}} 13.005$, de 25 de junho de 2014. Aprova o Plano Nacional de Educação PNE e dá outras providências. Brasília, DF, $2014 \mathrm{~b}$.

BRASIL. FNDE. Nota Técnica Conjunta $n^{0} 01 / 2017$. Nota técnica sobre metodologia de filtragem dos dados de matrículas do censo escolar para o Fundeb - 2018. Brasília, DF: Instituto Nacional de Estudos e Pesquisas Educacionais Anísio Teixeira, Dezembro de 2017.

BREMAEKER, François E. J. de. As receitas tributárias municipais em 2009. Transparência Municipal. Setembro, 2010.

CALEGARI, Cesar. O Fundeb e o financiamento da educação pública no Estado de São Paulo. 5.ed. atual. e ampliada. São Paulo: Aquariana: IBSA : APEOESP, 2010.

CAMARGO, Rubens Barbosa de et al. (Orgs.). Pesquisa nacional qualidade na educação: problematização da qualidade em pesquisa de Custo-Aluno-Ano em escolas de educação básica. Brasília, DF: INEP/MEC, 2006.

CAMARGO, Rubens Barbosa de; PINTO, José Marcelino de Rezende; GUIMARÃES, José Luiz. Sobre o financiamento no Plano de Desenvolvimento da Educação. Cadernos de Pesquisa, v.38, n.135, p.817-839, 2008. 
CARA, Daniel; ARAÚJO, Luiz. Por que 7\% do PIB para a educação é pouco? Cálculo dos investimentos adicionais necessários para o novo PNE garantir um padrão mínimo de qualidade. Campanha Nacional pelo Direito à Educação: nota técnica. 17 ago. 2011.

CARREIRA, Denise; PINTO, José Marcelino Rezende. Custo-Aluno-Qualidade Inicial: rumo à educação pública de qualidade no Brasil. São Paulo: Campanha Nacional pelo Direito à Educação, 2007.

CASTRO, Jorge Abrahão de. Financiamento da educação no Brasil. Em Aberto - Instituto Nacional de Estudos e Pesquisas Educacionais. Brasília, v. 18, n. 74, p. 11-32, dez. 2001.

CASTRO, Jorge Abrahão de; MENEZES, Raul Miranda. Avanços e Limites na Gestão da Política Federal de Ensino Fundamental nos Anos 1990. Textos para Discussão, IPEA, n. 947. Brasília: IPEA, 2003.

CASTRO, Jorge Abrahão de. Dilemas para o Financiamento da Educação. In; CUNHA, C. GADOTTI, M. BORDIGNON, G. NOGUEIRA, F. (orgs). O Sistema Nacional de Educação. Diversos olhares 80 anos após o Manifesto. MEC/UNESCO, 2014, pp.178-196.

CONSED. Financiamento da Educação nos Estados Brasileiros. Relatório Final de Pesquisa, Outubro de 2018.

COSTA, Marly de Abreu. Comparação das estimativas do custo/aluno em dois CIEPS e duas escolas convencionais do município do RJ. Educação e Sociedade, São Paulo, ano 12, n. 40, dez. 1991.

CURY, Carlos Roberto Jamil. Estado e políticas de financiamento em educação. Educ. Soc., Campinas, vol. 28, n. 100 - Especial, p. 831-855, out. 2007

DAVIES, Nicolas. O Fundef e o orçamento da educação: desvendando a caixa preta. Autores Associados, Campinas, 1999.

DAVIES, Nicholas. Solução ou remendo para o financiamento da educação básica? In: GOUVEIA, Andréa Barbosa; SOUZA, Ângelo Ricardo de; TAVARES, Taís Moura (Org.). Conversas sobre financiamento da educação no Brasil. Curitiba: Editora da UFPR, 2006. p. 43-70.

DOURADO, Luiz Fernandes; OLIVEIRA, João Ferreira de; SANTOS, Catarina de Almeida. A qualidade da educação: conceitos e definições. Série Documental: Textos para Discussão, Brasília (DF), v. 24, n. 22, p. 5-34, 2007.

FARENZENA, Nalú (Coord.). Levantamento do custo aluno/ano em escolas da educação básica que oferecem condições para a oferta de um ensino de qualidade. Porto Alegre: FACED/UFRGS - Núcleo de Estudos de Política e Gestão da Educação, 2004. Relatório de pesquisa.

FINEDUCA. Por que a União deve complementar o CAQi no PNE? Nota Técnica ${ }^{\circ}$ 01/2013. São Paulo: Fineduca, 2013. 
FÓRUM NACIONAL DE EDUCAÇÃO. Documento Final da II Conferência Nacional de Educação. Brasília, DF, 2015.

FRITSCH, Rosangela; VITELLI, Ricardo; ROCHA, Cleonice Silveira. Defasagem idadesérie em escolas de ensino médio do Rio Grande do Sul, Revista Brasileira de Estudos Pedagógicos, vol. 95, no. 239, Brasília, jan/abr 2014.

GUSMÃO, Joana Buarque. Significados da noção de qualidade da educação na arena educacional brasileira. Revista Brasileira de Estudos Pedagógicos, Brasília, v. 94, n. 236, p. 100-124, jan./abr. 2013 a.

GUSMÃO, Joana Buarque. A construção da noção de qualidade da educação. Ensaio: avaliação de políticas públicas educacionais, Rio de Janeiro, v. 21, n. 79, p. 299-322, abr./jun. $2013 b$.

GUTIERREZ, Dalva Valente Guimarães. Política de Municipalização do Ensino Fundamental no Estado do Pará na década de 1990 e suas Relações com a Reforma do Estado. Belém: UFPA, 2005. Disponível em: http://repositorio.ufpa.br/jspui/handle/2011/1690 Acesso em: $10 \mathrm{dez} 2018$.

IPEA. Carga Tributária Líquida e Efetiva Capacidade do Gasto Público no Brasil. Comunicado da Presidência, Brasília, n. 23, julho de 2009.

IPEA. Comunicado IPEA 124. Financiamento da Educação: necessidades e possibilidades. Dezembro de 2011.

JACOMINI, Márcia Aparecida. Porque a maioria dos pais e alunos defende a reprovação? Cadernos de Pesquisa, v. 40, n. 141, p. 895-919, set/dez 2010.

LIMONTI, R. M. ; PERES, U. D. ; CALDAS, E.. Política de fundos na educação e desigualdades municipais no estado de São Paulo: uma análise a partir das arenas políticas de Lowi. Revista de Administração Pública (Impresso), v. 48, p. 389-410, 2014.

MACHADO, Nelson. Sistema de informação de custo: diretrizes para integração ao orçamento público e à contabilidade governamental. Brasília: ENAP, 2005.

MACHADO, Nelson; HOLANDA, Victor Branco de. Diretrizes e modelo conceitual de custos para o setor público a partir da experiência no governo federal do Brasil. Revista de Administração Pública, v. 44(4), 791-820, Rio de Janeiro, Jul/Ago de 2010.

MANCILLA, Cláudio Andrés Barria. ECA, LDB e educação popular: perspectivas diversas para diversos fins. 29ª Reunião Anual da ANPED, Caxambu, 2006.

MAUSS, Cézar Volnei; SOUZA, Marcos Antônio de. Gestão de custos aplicada ao setor público: modelo para mensuração e análise da eficiência e eficácia governamental. São Paulo: Atlas, 2008.

MAY, T. Pesquisa social. Questões, métodos e processos. Porto Alegre, Artemed. 2001. 
MONLEVADE, Antonio Cabral de. Valorização salarial dos professores: o papel do piso salarial profissional nacional como instrumento de valorização dos professores de Educação Básica Pública. Campinas, UNICAMP, 2000.

MORAES, C. S. V.; LOPES NETO, Sebastião. A LDB e a Educação dos Trabalhadores. São Paulo em Perspectiva, Fundação SEADE, São Paulo - SP, v. 7, n. 1, p. 30-38, 1993.

OLIVEIRA, Romualdo Portela de. O financiamento da educação. In: OLIVEIRA, R. P.; ADRIÃO, T. Gestão, financiamento e análise da LDB da Constituição Federal. Xamã. São Paulo. 2001.

OLIVEIRA, Fabrício Augusto de. Economia e Política das Finanças Públicas: um guia de leitura à luz do processo de globalização e da realidade brasileira. Belo Horizonte, julho de 2007.

PARO, Vitor Henrique. Estudo comparativo sobre custo-aluno nos diversos graus e modali-dades de ensino. São Paulo: ATPCE; São Paulo: FCC, 1981.

PARO, Vitor Henrique. Progressão continuada, supervisão escolar e avaliação externa: implicações para a qualidade do ensino. Revista Brasileira de Educação, vol. 16, n. 28, Rio de Janeiro, set/dez. 2011.

PERES, Ursula Dias. Arranjo Institucional do Financiamento do Ensino Fundamental no Brasil: Considerações sobre os municípios brasileiros e estudo de caso do município de São Paulo no período de 1997 a 2006. Ano de obtenção 2007.

PERES, Ursula Dias; SANTOS, Fábio Pereira. Orçamento do Governo Federal: avanços e contradições na redução da desigualdade social (1995-2016). [Mimeo], São Paulo, 2019.

PINHO, Marcio. Reorganização atinge 311 mil alunos e 'disponibiliza' 94 escolas de SP. Portal de notícias G1, São Paulo, 26 out. 2015.

PINTO, José Marcelino de Rezende. Financiamento da educação do Brasil: da vinculação constitucional à construção de uma escola com padrões mínimos de qualidade. Linhas Críticas, Brasília, DF, v. 11, n. 20, p. 93-102, jan./jun. 2005.

PINTO, José Marcelino de Rezende. Uma proposta de custo-aluno-qualidade na educação básica. Revista Brasileira de Política e Administração da Educação, Porto Alegre, v. 22, n. 2, p. 197-227, jul./ dez. 2006.

PINTO, José Marcelino de Rezende. A política Recente dos Fundos para Financiamento da educação e seus efeitos para o pacto federativo. Educ. Soc., Campinas, vol. 28, n. 100 Especial, p. 877-897, out. 2007.

PINTO, José Marcelino de Rezende. O custo de uma educação de qualidade. In: CORREA, Bianca C.; GARCIA, Teise (Org.). Políticas educacionais e organização do trabalho na escola. São Paulo: Xamã, 2008. p. 57-80. 
PINTO, José Marcelino de Rezende. O Fundeb na perspectiva do custo aluno qualidade. Em Aberto, Brasília, v. 28, n. 93, p. 101-117, jan./jun. 2015.

PINTO, José Marcelino Rezende; CARA, Daniel; ARAÚJO, Luiz. Por que a União deve complementar o CaQi no PNE? Cálculo do quanto a União deve complementar os recursos do Fundeb para garantir um padrão mínimo de qualidade a todos/as os/as estudantes da educação básica. Associação Nacional de Pesquisa em Financiamento da Educação, Nota Técnica 1/2013. 24 set. 2013.

PROENÇA. Wander de Lara. O Método da Observação Participante: Contribuições e aplicabilidade para pesquisas no campo religioso brasileiro. Revista Aulas. no 4, São Paulo, abr 2007. Disponível em: $<$ http://www.unicamp.br/ aulas/Conjunto\%20III/4 23.pdf $>$ Acesso $10 \operatorname{dez} 2018$.

RAVITCH, D. Vida e morte do grande sistema escolar americano: como os testes padronizados e o modelo de mercado ameaçam a educação. Trad. de Marcelo Duarte. Porto Alegre: Sulina, 2011.

REZENDE, Fernando. Federalismo Fiscal: Novo Papel para Estados e Municípios. Julho 1997.

RODRIGUEZ, Vicente. Financiamento da educação e políticas públicas: o Fundef e a política de descentralização. Cadernos CEDES, Campinas, v. 21, n. 55, 2001.

SANO, H.; ABRUCIO, F.L. Promessas e resultados da nova gestão pública no Brasil: o caso das organizações sociais de saúde em São Paulo. Revista de Administração de Empresas (RAE), São Paulo, v. 48. n. 3, p. 64-80, 2008.

SÃO PAUlO. Decreto n. 58.030, de 12 de dezembro de 2017. Dispõe sobre a reorganização da Secretaria Municipal da Fazenda, e dá outras providências. São Paulo, SP, 2017a

SAVIANI, Demerval. Sistema Nacional de Educação e Plano Nacional de Educação: significado, controvérsias e perspectivas. Campinas, SP: Autores Associados, 2017.

SILVA, Maria José Ramos da. Custo direto de funcionamento do ensino médio público do Distrito Federal: um estudo de caso. Brasília, 2000. Dissertação (Mestrado em Educação)Pró-Reitoria de Pós- Graduação e Pesquisa, Universidade Católica de Brasília, Brasília, DF, 2000.

SOUSA, Sandra Zakia. Concepções de qualidade da educação básica forjadas por meio de avaliações em larga escala. Avaliação, Campinas; Sorocaba, SP, v. 19, n. 2, p. 407-420, jul. 2014.

TRIBUNAL DE CONTAS DO MUNICÍPIO DE SÃO PAULO. Relatório de Auditoria Programada. Avaliar a regularidade das contas que são objeto da presente fiscalização Gastos Educação, p. 1-28, Março de 2017.

TEIXEIRA, Anísio. Sobre o problema de como financiar a educação do povo brasileiro: bases para a discussão do financiamento dos sistemas públicos de educação. Em aberto, Vol. 28, No 93, p.147-160, 2015. 
TORRES, R. M. Educação para todos: a tarefa por fazer. Porto Alegre: Artmed, 2001.

UNESCO. Declaração Mundial sobre Educação para Todos. Plano de ação para satisfazer as necessidades básicas de aprendizagem. Tailândia, 1990.

UNIVERSIDADE DE SÃO PAULO (USP). Centro de Estudos e Pesquisas de Políticas Públicas em Educação. Levantamento do custo aluno/ano em escolas da Educação Básica que oferecem condições para oferta de um ensino de qualidade - São Paulo. São Paulo: INEP, 2004. Relatório de Pesquisa. Não publicado.

UNIVERSIDADE FEDERAL DE GOIÁS (UFG). Levantamento do custo-aluno ano em escolas da Educação Básica que oferecem condições para oferta de um ensino de qualidade. Goiânia: UFG; Brasília, DF: INEP, 2003. Plano de Trabalho. Não publicado.

UNIVERSIDADE FEDERAL DE GOIÁS (UFG). Faculdade de Educação. Pesquisa custoaluno qualidade. Goiânia: INEP, 2004. Relatório Final, v. 2. Não publicado.

UNIVERSIDADE FEDERAL DO PARÁ (UFPA). Grupo de Estudos em Gestão e Financiamento da Educação (GEFIN). Levantamento do custo-aluno-ano em escolas da educação básica que oferecem condições de um ensino de qualidade. Belém: INEP, 2004. Relatório Final de Pesquisa. Não publicado.

UNIVERSIDADE FEDERAL DO PARANÁ (UFPR). Departamento de Planejamento e Administração Escolar. Levantamento do custo aluno em escolas que oferecem condições de qualidade - Paraná. Curitiba: Setor de Educação, INEP, 2004. Relatório de Pesquisa. Não publicado.

UNIVERSIDADE FEDERAL DO RIO GRANDE DO SUL (UFRS). Núcleo de Estudos de Política e Gestão da Educação. Levantamento do custo aluno/ano em escolas da Educação Básica que oferecem condições para oferta de um ensino de qualidade - Porto Alegre. Porto Alegre: INEP, 2004. Relatório de Pesquisa. Não publicado.

VERHINE, Robert E. Pesquisa Nacional Qualidade na Educação: custo-aluno-qualidade em escolas de educação básica: Brasília, DF: INEP; MEC, 2006.

XAVIER, Antônio Carlos da Ressurreição; AMARAL SOBRINHO, José; PLANK, David N. Os padrões mínimos de qualidade dos serviços educacionais: uma estratégia de alocação de recursos para o ensino fundamental. In: GOMES, Candido Alberto; AMARAL SOBRINHO, José (Org.). Qualidade, eficiência e equidade na educação básica. Brasília, DF: IPEA, 1992. p. 71-98. (Série IPEA, n. 136).

ZANETTI, Maria Aparecida. Política Educacional e LDB: Algumas Reflexões. 1997

WONG, Laura L.; CARVALHO, J. A. O rápido processo de envelhecimento populacional do Brasil: sérios desafios para as políticas públicas. Revista Brasileira de Estudos da População. Vol. 23, n. 1, São Paulo, Jan 2006. 


\section{ANEXO A - CATEGORIAS PARA ANÁLISE DE CUSTOS DA REDE MUNICIPAL DE SÃO PAULO}

Tabela 1

Classificações da Despesa

continua

\begin{tabular}{|c|c|}
\hline Categoria & Variável \\
\hline \multicolumn{2}{|l|}{ Econômica } \\
\hline & Pessoal \\
\hline & Bens e Serviços \\
\hline & Contratos de Terceirização da Atividade Fim \\
\hline & Demais gastos \\
\hline \multicolumn{2}{|l|}{ Finalidade } \\
\hline & Educacional \\
\hline & Assistencial \\
\hline & Cultural \\
\hline & Esportiva \\
\hline & Demais gastos \\
\hline \multicolumn{2}{|c|}{ Etapas de Ensino } \\
\hline & Creche \\
\hline & Pré-Escola \\
\hline & Ensino Fundamental \\
\hline & Ensino Médio \\
\hline \multicolumn{2}{|l|}{$\overline{\text { Rede }}$} \\
\hline & Conveniada \\
\hline & Direta \\
\hline \multicolumn{2}{|l|}{ Insumos } \\
\hline & Acesso e Permanência Estudantil \\
\hline & Ações e materiais de apoio Didático-Pedagógico \\
\hline & Aquisição, Locação, Construção, Ampliação e Reforma de Edificações \\
\hline & Armazenagem, Logística e Locomoção \\
\hline & Demais gastos \\
\hline & Formação de Recursos Humanos \\
\hline & Outros Serviços de Terceiros \\
\hline & Políticas de Avaliação Escolar \\
\hline & Publicidade Institucional \\
\hline & Serviços Básicos \\
\hline & Serviços de Manutenção e Apoio \\
\hline & Servidores e Funcionários \\
\hline & Tecnologia da Informação \\
\hline & Transferência Financeira \\
\hline
\end{tabular}




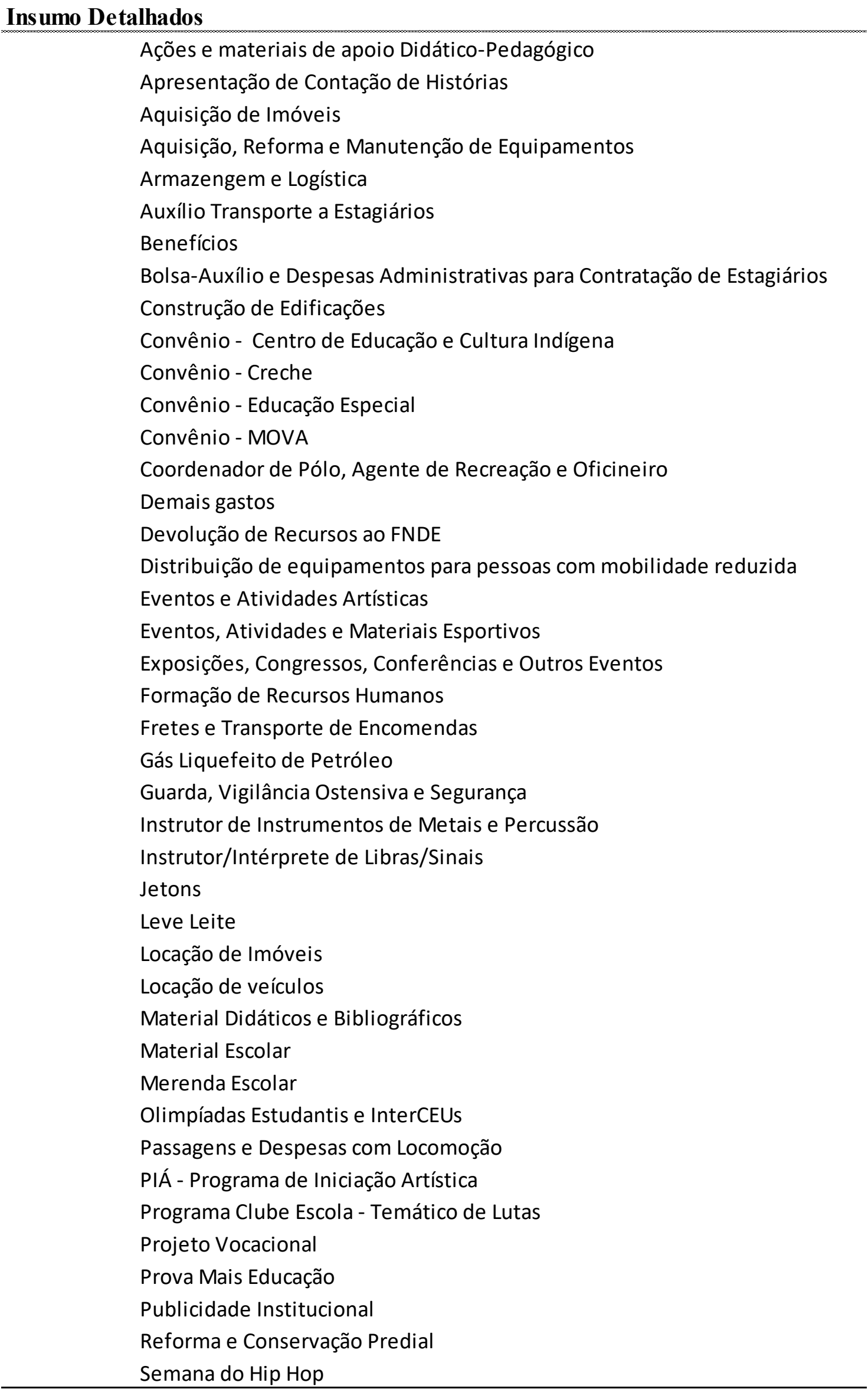


continua

Serviço de Instalação, Ampliação de Sist. de Telefonia/Teleinformática Serviços de Água e Esgoto

Serviços de Áudio, Vídeo e Foto

Serviços de Energia Elétrica e Iluminação Pública

Serviços de Socorro e Salvamento

Serviços e Materiais de Apoio Administrativo, Técnico e Operacional

Serviços e Materiais de Copa e Cozinha

Serviços e Materiais de Limpeza e Conservação

Técnicos na Área Cultural e Artística

Tecnologia da Informação

Telefonia Fixa e Móvel

Transferência de Recursos para as Unidades Educacionais

Transporte Escolar

Uniforme Escolar

Vencimentos e Vantagens Fixas

Virada Cultural 


\section{ANEXO B - MEMÓRIA DE CÁLCULO DOS INSUMOS DETALHADOS}

A tabela deste anexo se refere a memória de cálculo da variável insumos detalhados, para esta consolidação utilizou-se as seguintes variáveis: item de despesa, subelemento, observações de empenho, projeto, subfunção, razão social, finalidade e os insumos detalhados pré-classificados.

Um insumo detalhado pode conter uma ou mais variáveis, e ainda, derivar de uma seleção única ou múltipla. Na seleção única não se aplica nenhum filtro, deste modo, todos os registros são selecionados. Para identificar a seleção múltipla utiliza-se os sinais de "+" e "-" para representarem filtros realizados no respectivo conjunto de dados, o sinal "+" orienta que SOMENTE os registros da variável a frente serão considerados no conjunto acima e o sinal "““ representa que foram desconsiderados os registros na variável a frente, significa EXCETO. Abaixo três exemplos para compreender a organização dos dados.

Exemplo 1. Um insumo detalhado formado por uma única variável.

Na execução orçamentária o programa "Leve Leite" é facilmente identificado, pois a execução orçamentária ocorre no Projeto "Leve Leite", por isso, o insumo detalhado "Leve Leite" se refere, exclusivamente a variável projeto e ao registro "Leve Leite".

\begin{tabular}{|l|}
\hline Leve Leite \\
\hline Projeto \\
\hline
\end{tabular}

Exemplo 2. Insumo detalhado formado por múltiplas seleções, representação de SOMENTE (“+”)

O insumo detalhado "Guarda, Vigilância Ostensiva e Segurança Geral” é composto por três conjuntos de registros da variável item de despesa. Os dois primeiros conjuntos de dados ("Guarda, Vigilância e Segurança em Geral" e "Vigilância Ostensiva") são considerados integralmente. No terceiro conjunto de dados ("Outras Despesas de Exercícios Anteriores / Outras Despesas Correntes") SOMENTE serão considerados os registros determinados pela variável razão social. Em “Outras Despesas de Exercícios Anteriores / Outras Despesas Correntes" há o registro de liquidação de 35 empresas, mas somente 6 delas compõem a variável. 


\begin{tabular}{|l|l|}
\hline \multicolumn{2}{|l|}{ Guarda, Vigilância Ostensiva e Segurança } \\
\hline Item de Despesa Guarda, Vigilância e Segurança em Geral \\
\hline Item de Despesa Vigilância Ostensiva \\
\hline Item de Despesa Outras Despesas de Exercícios Anteriores / Outras Despesas Correntes \\
$+\quad$ RAZÃO SOCIAL: G4S VANGUARDA SEGURANCA E VIGILANCIA LTDA \\
POWER - SEGURANÇA E VIGILANCIA LTDA \\
PLURI SEGURANÇA E VIGILANCIA LTDA \\
CENTURION SEGURANÇA E VIGILANCIA LTDA \\
PROSEG SEGURANÇA E VIGILÂNCIA LTDA \\
COPSEG SEGURANÇA E VIGILÂNCIA LTDA
\end{tabular}

Exemplo 3. Insumo detalhado formado por multiplas seleções, representação de EXCETO (“+”)

O insumo "Distribuição de equipamentos para pessoas com mobilidade reduzida" é composto por duas variáveis, observações de empenho e razão social, no primeiro todos os registros de "aquisição de mobiliário adaptado serão considerados, no segundo, há uma exceção, não são contabilizados os registros da "METALPLAY INDÚSTRIA E COMÉRCIO LTDA EPP" que já foram classificados pelo insumo detalhado “Aquisição, Reforma e Manutenção de Equipamentos.

\begin{tabular}{|ll|}
\hline Dis tribuição de equipame ntos para pessoas com mobilidade reduzida \\
\hline Observações de empenho & AQUISIÇÃO DE MOBILIÁRIO ADAPTADO \\
\hline RAZÃO SOCIAL & METALPLAY INDÚSTRIA E COMÉRCIO LTDA EPP \\
- & Insumo detalhado: Aquisição, Reforma e Manutenção de Equipamentos \\
\hline
\end{tabular}


Tabela I

Memória de cálculo dos insumos detalhados

\begin{tabular}{|c|c|}
\hline $\begin{array}{l}\text { Categoria Econômica| } \\
\text { Finalidade| Ins umos | } \\
\text { Insumos Detalhados | } \\
\text { Variável Analis ada ou Sinal } \\
\text { ( "-" e "+") }\end{array}$ & Registro ou Variável e Regis tro \\
\hline \multicolumn{2}{|l|}{ Bens e Serviços } \\
\hline \multicolumn{2}{|l|}{ Assistencial } \\
\hline \multicolumn{2}{|l|}{ Leve Leite } \\
\hline Projeto & Leve Leite \\
\hline \multicolumn{2}{|l|}{ Uniforme Escolar } \\
\hline Item de Despesa & Uniforme Escolar \\
\hline RAZÃO SOCIAL & CAPRICORNIO S/A \\
\hline \multicolumn{2}{|c|}{ Dis tribuição de equipamentos para pess oas com mobilidade reduzida } \\
\hline Observações de empenho & AQUISIÇÃO DE MOBILIÁRIO ADAPTADO \\
\hline RAZÃO SOCIAL & METALPLAY INDÚSTRIA E COMÉRCIO LTDA EPP \\
\hline- & Insumo detalhado: $\quad$ Aquisição, Reforma e Manutenção de Equipamentos \\
\hline \multicolumn{2}{|l|}{ Cultural } \\
\hline \multicolumn{2}{|c|}{ Apresentação de Contação de His tórias } \\
\hline Subelemento & Exposições, Congressos, Conferências e Outros Eventos \\
\hline+ & Observações de empenho. Apresentação de Contação de Histórias \\
\hline \multicolumn{2}{|l|}{ Semana do Hip Hop } \\
\hline Subelemento & Exposições, Congressos, Conferências e Outros Eventos \\
\hline \multirow[t]{2}{*}{+} & Observações de empenho. Hip Hop \\
\hline & $\begin{array}{l}\text { Apresentação artística dos grupos conforme proposta em anexo, durante o evento Mês do HIP } \\
\text { HOP } 2016\end{array}$ \\
\hline \multicolumn{2}{|l|}{ Virada Cultural } \\
\hline Subelemento & Exposições, Congressos, Conferências e Outros Eventos \\
\hline+ & Observações de empenho. VIRADA CULTURAL \\
\hline \multicolumn{2}{|l|}{ Projeto Vocacional } \\
\hline Item de Despesa & Projeto Vocacional \\
\hline Observações de empenho & SMC/SME - PROGRAMA VOCACIONAL - Contribuição Social Previdenciária Patronal. $\square$ \\
\hline
\end{tabular}




\section{PIÁ - Programa de Iniciação Artística}

Item de Despesa

PIÁ - Programa de Iniciação Artística

Observações de empenho SMC/SME - PROGRAMA PIÁ - Contribuição Social Previdenciária Patronal.

\section{Eventos e Atividades Artísticas}

Subelemento Exposições, Congressos, Conferências e Outros Eventos

Observações de empenho. Apresentações do Espetáculo

Apresentação do Espetáculo

Contratação Artística - Espetáculo

Apresentação de Show Musical

CONTRATAÇÃO ARTISTICA -PROJETO MARÇO MULHER (e variações)

Contratação Artística - Show Musical

Contratação art

- $\quad$ Insumo detalhado: $\quad$ Formação de Recursos Humanos

- Finalidade: $\quad$ Todas as variáveis com finalidade cultural classificadas acima

$+\quad$ Observações de empenho.CONTRATAÇÃO DE EVENTOS

$\begin{array}{lll} & - & \text { Virada Cultural } \\ \text { RAZÃO SOCIAL } & \text { SOCIEDADE DE CONCERTOS DE SÃO PAULO }\end{array}$

Esportiva

Eventos, Atividades e Mate riais Esportivos

\begin{tabular}{|c|c|}
\hline Subelemento & Material Educativo e Esportivo \\
\hline- & Formação de Recursos Humanos \\
\hline Subelemento & Exposições, Congressos, Conferências e Outros Eventos \\
\hline+ & Observações de empenho. Arbitro/Arbitragem \\
\hline & Troféu/Medalha \\
\hline Subelemento & Confecção de Uniformes, Bandeiras e Flâmulas \\
\hline Subelemento & Premiações Desportivas \\
\hline Subelemento & Serviços Técnicos Profissionais \\
\hline+ & Observações de empenho. Arbitro/Arbitragem \\
\hline Item de Despesa & Uniformes Esportivos \\
\hline \multicolumn{2}{|c|}{ Programa Clube Escola - Temático de Lutas } \\
\hline Subelemento & Exposições, Congressos, Conferências e Outros Eventos \\
\hline+ & Observações de empenho.Programa Clube Escola - Temático de Lutas \\
\hline
\end{tabular}


Olimpíadas Estudantis e InterCEUs

\begin{tabular}{|c|c|}
\hline $\begin{array}{l}\text { Subelemento } \\
+\quad\end{array}$ & $\begin{array}{l}\text { Exposições, Congressos, Conferências e Outros Eventos } \\
\text { Observações de empenho. Olimpíadas Estudantis e InterCEUs }\end{array}$ \\
\hline \multicolumn{2}{|c|}{ Socorro e Salvamento } \\
\hline Subelemento & Serviços de Socorro e Salvamento \\
\hline \multicolumn{2}{|l|}{ Educacional } \\
\hline \multirow{2}{*}{\multicolumn{2}{|c|}{$\begin{array}{l}\text { Ações e materiais de apoio Didático-Pedagógico } \\
\text { Ações e materiais de apoio Didático-Pedagógico }\end{array}$}} \\
\hline & \\
\hline Subelemento & Outros Materiais de Consumo \\
\hline 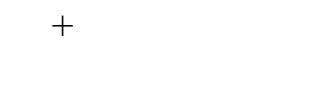 & $\begin{array}{l}\text { Observações de empenho. brinquedo } \\
\text { AQUISIÇÃO DE KITS DE ROBÓTICA EDUCACIONAL }\end{array}$ \\
\hline $\begin{array}{l}\text { Subelemento } \\
+\end{array}$ & $\begin{array}{l}\text { Exposições, Congressos, Conferências e Outros Eventos } \\
\text { Observações de empenho. brinquedo/recreio nas férias }\end{array}$ \\
\hline $\begin{array}{l}\text { Subelemento } \\
+\end{array}$ & $\begin{array}{l}\text { Uniformes, Tecidos e Aviamentos } \\
\text { Observações de empenho. Recreio }\end{array}$ \\
\hline \multicolumn{2}{|c|}{ Exposições, Congressos, Conferências e Outros Eventos } \\
\hline $\begin{array}{l}\text { Subelemento } \\
-\end{array}$ & $\begin{array}{l}\text { Exposições, Congressos, Conferências e Outros Eventos } \\
\text { Finalidade: } \\
\text { Cultural } \\
\text { Esportiva }\end{array}$ \\
\hline \multicolumn{2}{|c|}{ Material Didáticos e Bibliográficos } \\
\hline Item de Despesa & Livros \\
\hline Item de Despesa & Diversos Materiais Bibliográficos Não Imobilizáveis \\
\hline Item de Despesa & Apostilas, Almanaques, Folhetos e Periódicos \\
\hline $\begin{array}{l}\text { Item de Despesa } \\
\text { - }\end{array}$ & $\begin{array}{l}\text { Materiais Didáticos } \\
\text { Observações de empenho. Brinquedo } \\
\qquad \text { Impressão dos cadernos da "PROVA MAIS EDUCAÇÃO" }\end{array}$ \\
\hline
\end{tabular}

Serviços de Áudio, Víde o e Foto

Subelemento Serviços de Áudio, Vídeo e Foto 
Serviços de Manutenção e Apoio

Aquisição, Reforma e Manutenção de Equipamentos

\begin{tabular}{ll}
\hline Subelemento & Mobiliário em Geral \\
\hline Subelemento & Outros Materiais de Consumo \\
+ & Observações de empenho. Colchonetes
\end{tabular}

Lençóis infantis

babador

Giz

Camas

Lenço umedecido

Placa de identificação

Alambrado

\begin{tabular}{|c|c|}
\hline Subelemento & Material de Cama, Mesa e Banho \\
\hline Subelemento & Equipamentos para Vídeo, Áudio e Foto \\
\hline Subelemento & Material Farmacológico \\
\hline Subelemento & Material Hospitalar \\
\hline- & Formação de Recursos Humanos \\
\hline Subelemento & Material para Manutenção de Bens Móveis \\
\hline- & Insumo detalhado: $\quad$ Formação de Recursos Humanos \\
\hline Subelemento & Material de Sinalização Visual e Afins \\
\hline Subelemento & Material Odontológico \\
\hline Subelemento & Outros Equipamentos e Materiais Permanentes \\
\hline- & Insumo detalhado: $\quad$ Tecnologia da Informação \\
\hline & Distribuição de equipamentos para pessoas com mobilidade reduzida \\
\hline Subelemento & Aparelhos e Equipamentos p/ Esportes e Diversões \\
\hline Observações de empenho & AQUISIÇÃO DE MOBILIÁRIO ADAPTADO \\
\hline Observações de empenho & Aquisição de telescópio monocular para o aluno IGOR CORNEJO LEITE SALES \\
\hline & SP-SM (S. MATEUS) - AQUIS. DE PARAPODIUN E MESA ADAPATADA - EMEF PROFa VIRGINIA \\
\hline Observações de empenho & L.Z.CAMARGO E EMEF RODRIGO MELO FRANCO \\
\hline Observações de empenho & SP-VP/SB (SAPOPEMBA) - AQUIS. DE CANTINHO ADAPTADO - EMEI ROSA DA CHINA \\
\hline Observações de empenho & CONFECÇÃO DE CORTINAS \\
\hline Observações de empenho & CONFECÇÃO DE ARMÁRIO TIPO COLMEIA 210 CAIXAS \\
\hline Observações de empenho & AQUISIÇÃO DE LENÇOL COM ELÁSTICO \\
\hline
\end{tabular}




\begin{tabular}{|c|c|}
\hline Item de Despesa & Pequenas Reformas - Móveis \\
\hline Item de Despesa & Pequenas Reformas - Carteira Escolar e Similares \\
\hline- & Formação em Recursos Humanos \\
\hline Item de Despesa & Bebedouro \\
\hline Item de Despesa & Outras Máquinas, Utensílios e Equipamentos Diversos \\
\hline \multicolumn{2}{|c|}{ Guarda, Vigilância Ostensiva e Segurança } \\
\hline Item de Despesa & Outras Despesas de Exercícios Anteriores / Outras Despesas Correntes \\
\hline \multirow[t]{4}{*}{+} & G4S VANGUARDA SEGURANCA E VIGILANCIA LTDA \\
\hline & POWER - SEGURANÇA E VIGILANCIA LTDA \\
\hline & PLURI SEGURANÇA E VIGILANCIA LTDA \\
\hline & CENTURION SEGURANÇA E VIGILANCIA LTDA \\
\hline Item de Despesa & Copeiragem \\
\hline Item de Despesa & Serviços de Copa e Cozinha \\
\hline Item de Despesa & Diversos Materiais de Copa e Cozinha \\
\hline Subelemento & Material de Acondicionamento e Embalagem \\
\hline Subelemento & Gêneros de Alimentação \\
\hline- & Merenda Escolar \\
\hline Subelemento & Fornecimento de Alimentação \\
\hline- & $\begin{array}{ll}\text { Insumo detalhado: } & \text { Formação de Recursos Humanos } \\
& \text { Merenda Escolar }\end{array}$ \\
\hline RAZÃO SOCIAL & INGÁ COMERCIAL ATACADISTA LTDA. \\
\hline RAZÃO SOCIAL & JOTABE SERVIÇOS TECNICOS ESPECIALIZADOS LTDA \\
\hline
\end{tabular}




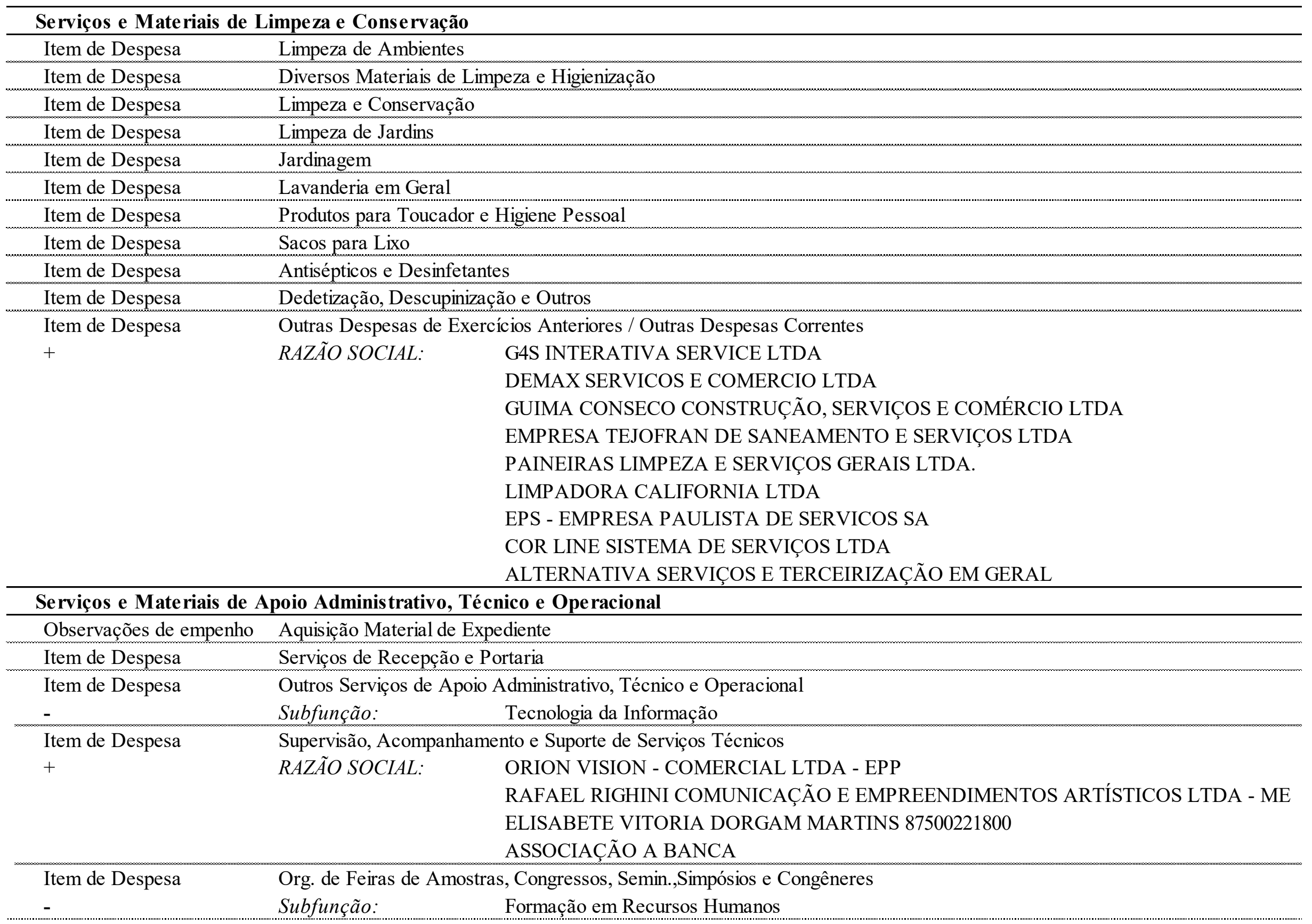




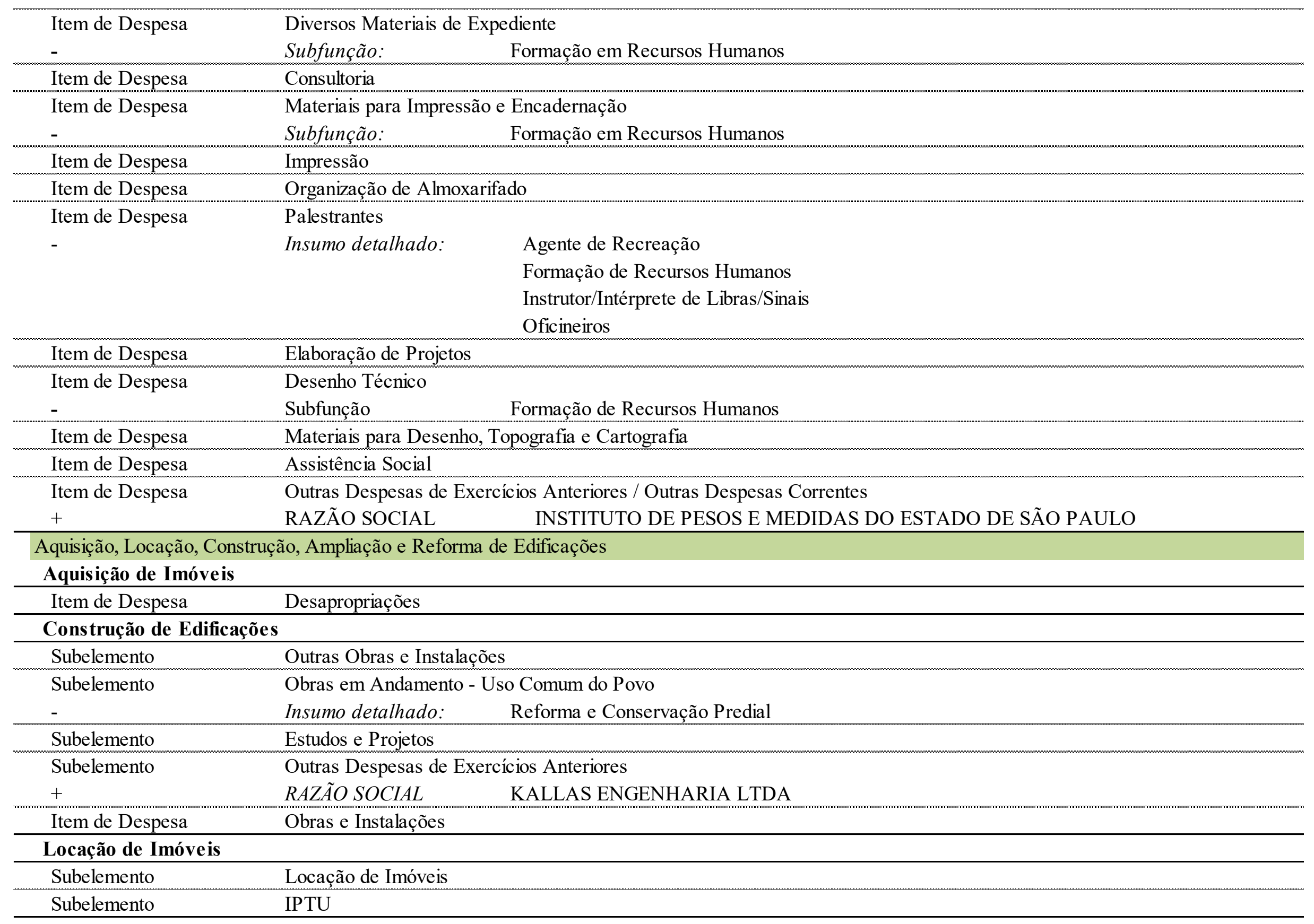




\begin{tabular}{|c|c|}
\hline \multicolumn{2}{|c|}{ Reforma e Conservação Predial } \\
\hline Subelemento & Manutenção e Conservação de Bens Imóveis \\
\hline Subelemento & Manut. e Conserv. de Máquinas e Equipamentos \\
\hline- & Tecnologia da Informação \\
\hline Subelemento & Serviços Urbanos \\
\hline Subelemento & Outros Serv. de Terceiros Pessoa Jurídica - Pagto Antecipado \\
\hline- & Insumo detalhado: \\
\hline & Formação de Recursos Humanos \\
\hline Subelemento & Locação de Máquinas e Equipamentos \\
\hline Subelemento & Material para Manutenção de Bens Imóveis \\
\hline Subelemento & Material Elétrico e Eletrônico \\
\hline Subelemento & Equipamentos e Utensílios Hidráulicos e Elétricos \\
\hline Sublemento & Serviços de Terceiros - Pessoa Jurídica \\
\hline+ & Razão Social: $\quad$ PCT ENGENHARIA E CONSTRUÇÕES LTDA \\
\hline RAZÃO SOCIAL & ERA-TECNICA ENGENHARIA CONSTRUÇÕES E SERVIÇOS LTDA \\
\hline RAZÃO SOCIAL & ENGENHARIA E COMERCIO RIGEL LTDA \\
\hline RAZÃO SOCIAL & PROVENCE CONSTRUTORA LTDA \\
\hline RAZÃO SOCIAL & MAS CONSTRUÇÕES E EMPREENDIMENTOS LTDA \\
\hline RAZÃO SOCIAL & HE ENGENHARIA COMÉRCIO E REPRESENTAÇÕES LTDA \\
\hline Item de Despesa & Lâmpadas - Iluminação Pública \\
\hline Item de Despesa & Lâmpadas - Imóveis Administrativos \\
\hline Item de Despesa & Manutenção em Equipamentos de Proteção e Segurança Pessoal \\
\hline Item de Despesa & Material de Proteção e Segurança de Bens Públicos \\
\hline Item de Despesa & Engenharia (exceto constr. estradas, pontes, prédios e obras assem.) \\
\hline Item de Despesa & Bens Móveis \\
\hline+ & Observações de empenho. Extintores, Toldos, Persianas e Ar condicionado \\
\hline Item de Despesa & Aparelho de Ar-Condicionado \\
\hline Item de Despesa & Outros Materiais de Consumo \\
\hline+ & Observações de empenho.DL - AQUISIÇÃO DE PEÇAS PARA ELEVADORES \\
\hline & MANUTENÇÃO E CONSERTO DE AR CONDICIONADO - DOT P \\
\hline Observações de empenho & Serv. De Manutenção de Ar Condicionado \\
\hline Observações de empenho & CONSERTO DO AR CONDIICONADO DO TEATRO DE CEU VILA DO SOL \\
\hline Observações de empenho & SP/CS - Teatro CEU Parelheiros - Serviços Técnicos - Sistemas de Ar Condicionado. \\
\hline
\end{tabular}




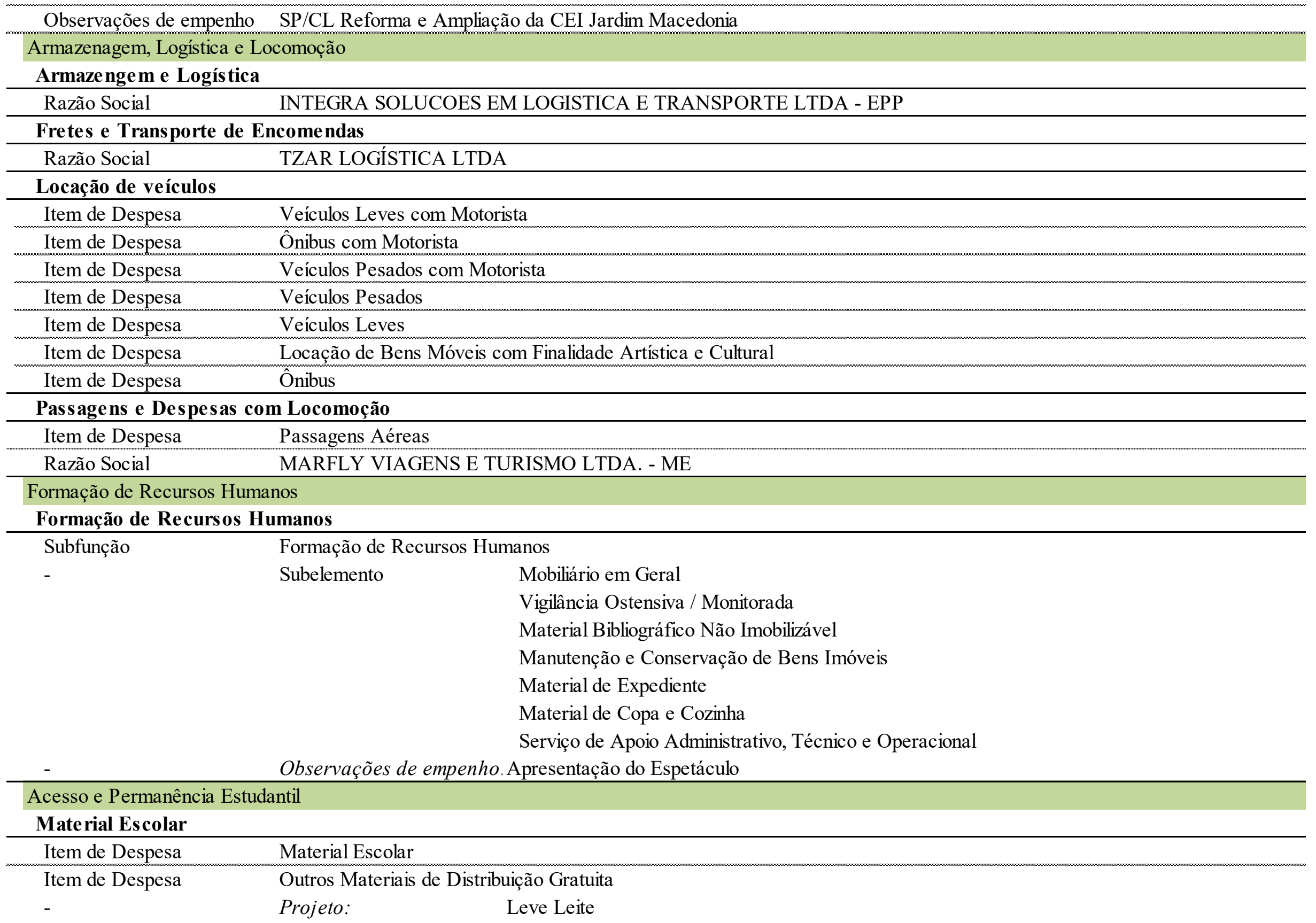


Insumo detalhado: $\quad$ Distribuição de equipamentos para pessoas com mobilidade reduzida Aquisição, Reforma e Manutenção de Equipamentos

\begin{tabular}{|c|c|}
\hline \multicolumn{2}{|l|}{ Merenda Escolar } \\
\hline Projeto & Alimentação Escolar \\
\hline Projeto & Programa Nacional de Alimentação Escolar - PNAE/ FNDE \\
\hline \multicolumn{2}{|l|}{ Transporte Escolar } \\
\hline Projeto & Transporte Escolar \\
\hline- & Subelemento: \\
\hline \multicolumn{2}{|c|}{ Publicidade Institucional } \\
\hline \multicolumn{2}{|c|}{ Publicidade Institucional } \\
\hline Item de Despesa & Publicidade Institucional \\
\hline Item de Despesa & Publicidade Legal \\
\hline \multicolumn{2}{|l|}{ Serviços Básicos } \\
\hline \multicolumn{2}{|c|}{ Gás Lique fe ito de Petróleo } \\
\hline RAZÃO SOCIAL & COMPANHIA ULTRAGAZ S/A. \\
\hline RAZÃO SOCIAL & COMPANHIA ULTRAGAZ S A \\
\hline Item de Despesa & Gás Canalizado \\
\hline Item de Despesa & Instalação, Ampliação de Rede de Tubulação de Gás \\
\hline Subelemento & Gás e Outros Materiais Engarrafados \\
\hline \multicolumn{2}{|c|}{ Serviço de Instalação, Ampliação de Sist. de Telefonia/Teleinformática } \\
\hline Item de Despesa & Serviço de Instalação, Ampliação de Sist. de Telefonia/Teleinformática \\
\hline \multicolumn{2}{|c|}{ Serviços de Água e Esgoto } \\
\hline Item de Despesa & Água e Esgoto \\
\hline \multicolumn{2}{|c|}{ Serviços de Energia Elétrica e Iluminação Pública } \\
\hline Item de Despesa & Energia Elétrica de Prédios Públicos \\
\hline Item de Despesa & Serviços de Instalação de Rede de Energia \\
\hline Item de Despesa & Serviços de Fornecimento de Energia Elétrica e Iluminação Pública \\
\hline Subelemento & Outras Despesas de Exercícios Anteriores / Outras Despesas Correntes \\
\hline+ & ELETROPAULO METROPOLITANA ELETRICIDADE DE SÃO PAULO S.A \\
\hline \multicolumn{2}{|c|}{ Telefonia Fixa e Móvel } \\
\hline Item de Despesa & Telefonia Fixa \\
\hline Item de Despesa & Telefonia Móvel \\
\hline
\end{tabular}


Tecnologia da Informação

Tecnologia da Informação

Subfunção Tecnologia da Informação

Transferência Financeira

Devolução de Recursos ao FNDE

Subelemento Restituições

Trans fe rência de Recursos para as Unidades Educacionais

Projeto

Transferência de Recursos Financeiros para as Unidades Educacionais

Políticas de Avaliação Escolar

Prova Mais Educação

Observações de empenho PROVA MAIS EDUCAÇÃO- Utilização da Ata de Registro de Preços nº 19/SME/2016

Aquisição de mídias/DVD para impressão - PROVA MAIS EDUCAÇÃO SÃO PAULO

Impressão dos cadernos da "PROVA MAIS EDUCAÇÃO"

\section{Contratos de Tercerização da Atividade Fim}

Educacional

Convênio - Creche

\begin{tabular}{lll}
\hline \multicolumn{1}{c}{ Item de Despesa } & Contrato de Gestão & \\
\hline Item de Despesa & Convênio - Creche & \\
\hline Subelemento & Indenizações e Restituições \\
+ & Razão Social: & ASSOCIAÇÃO VALE VERDE \\
& & INSTITUTO BENEFICENTE CULTURAL JOSE KENTENICH \\
& MOVIMENTO DE DEFESA DO FAVELADO REGIÃO EPISCOPAL BELEM \\
& CENTRO DE ASSISTÊNCIA E PROMOÇÃO SOCIAL NOSSO LAR \\
& SOCIEDADE AGOSTINIANA DE EDUCAÇÃO E ASSISTENCIA \\
& ASSOCIAÇÃO BENEFICENTE VIRTUDE DA CRIANÇA \\
& CENTRO ASSISTENCIAL SANTA ÂNGELA - CASA
\end{tabular}

Sublemento

Serviços de Terceiros - Pessoa Jurídica

Razão Social: $\quad$ ASSOCIAÇÃO BENEFICENTE PRESENTE DE DEUS

CENTRO SOCIAL NOSSA SENHORA DO BOM PARTO

CENTRO SOCIAL NOSSA SENHORA DO BOM PARTO

INSTITUTO SÃO PAULO MELHOR 
NUCLEO RECREATIVO MUNDO ENCANTADO

SOCIEDADE BENEFICIENTE EQUILIBRIO DE INTERLAGOS

NÚCLEO DE PROMOÇÃO SOCIAL VENHA CONOSCO

INSTITUTO CRIANÇA CIDADÂ

FUNDESP FUNDAÇÃO ESPERANÇA

MOCA - MOVIMENTO DE ORIENTAÇÃO À CRIANÇA E AO ADOLESCENTE

CENTRO SOCIAL DA PAROQUIA SANTA LUZIA

ORG.NAC.DE DEFESA E APOIO DA CRIANÇA E ADOL. DO IDOSO E DO M. AMB.

GSS GRUPO SEMPRE SERVINDO

CENTRO COMUNITARIO JARDIM AUTODROMO

\begin{tabular}{|c|c|}
\hline Item de Despesa & Convênios - Alfabetização, Educação e Outros \\
\hline+ & FUNDESP FUNDAÇÃO ESPERANÇA \\
\hline Subelemento & Indenizações e Restituições \\
\hline Sublemento & Serviços de Terceiros - Pessoa Jurídica \\
\hline \multirow[t]{2}{*}{+} & ASSOC A CRIANCA ADOLES JOV. ICARAI \\
\hline & ENTIDADE DE PROMOÇÃO E ASSISTÊNCIA SOCIAL ESPAÇO ABERTO \\
\hline \multirow[t]{2}{*}{-} & Material Didáticos e Bibliográficos \\
\hline & Serviços e Materiais de Copa e Cozinha \\
\hline \multicolumn{2}{|c|}{ Observações de empenho MOVA - CENTRO DE ASSISTENCIA SOCIAL DO JD PERI } \\
\hline \multicolumn{2}{|c|}{ Convênio - Educação Especial } \\
\hline Projeto & Convênios para Atendimento de Crianças e Adolescentes com necessidades Educacionais Especiais \\
\hline
\end{tabular}




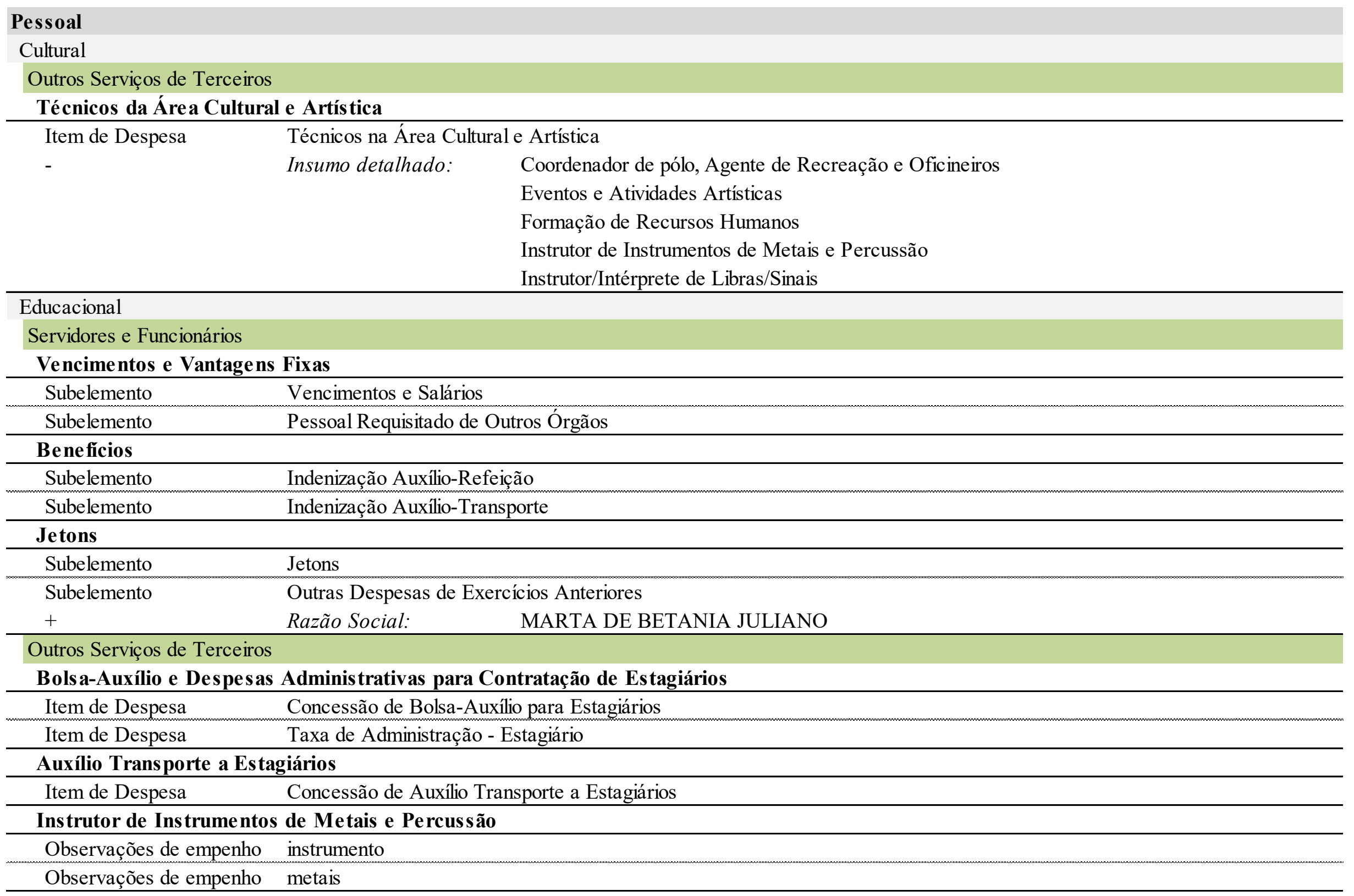




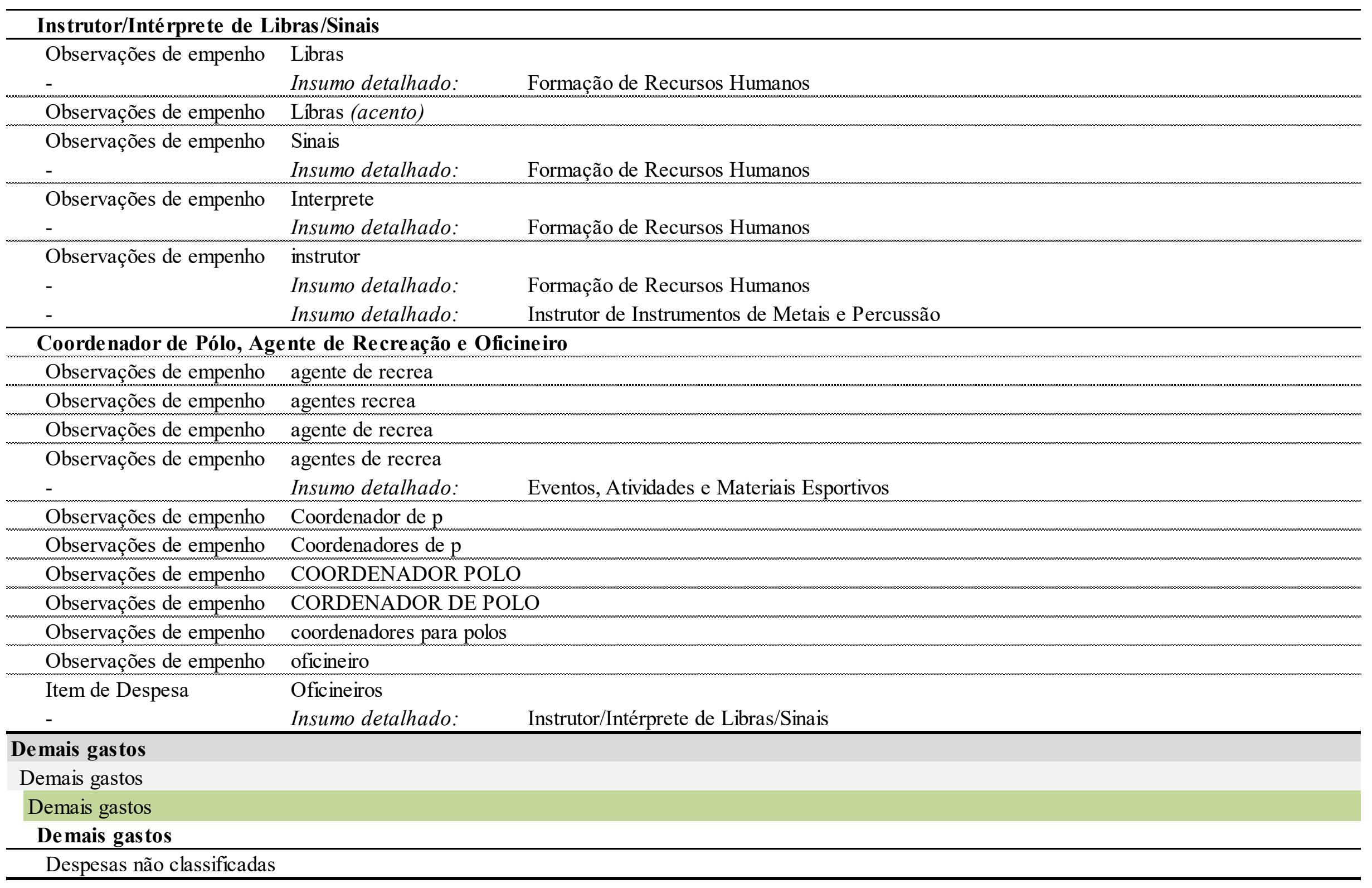

